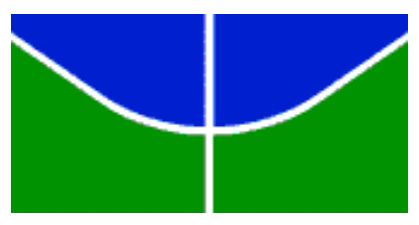

UNIVERSIDADE DE BRASÍLIA

FACULDADE DE AGRONOMIA E MEDICINA VETERINÁRIA

\author{
ESTUDO DA INTERFERÊNCIA DE SUBSTRATOS \\ ORGÂNICOS NA AÇÃO DO OZÔNIO SOBRE \\ MICRORGANISMOS DETERIORANTES, BENÉFICOS E \\ PATOGÊNICOS
}

STEFANIA MARCIA DE OLIVEIRA SOUZA

TESE DE DOUTORADO EM CIÊNCIAS ANIMAIS

BRASÍLIA-DF

DEZEMBRO DE 2016 


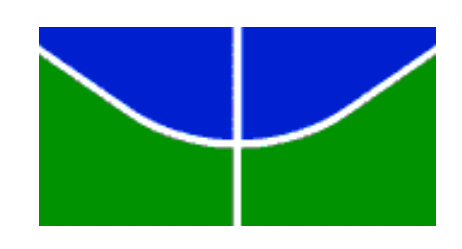

UNIVERSIDADE DE BRASÍLIA

FACULDADE DE AGRONOMIA E MEDICINA VETERINÁRIA

\section{ESTUDO DA INTERFERÊNCIA DE SUBSTRATOS ORGÂNICOS NA AÇÃO DO OZÔNIO SOBRE MICRORGANISMOS DETERIORANTES, BENÉFICOS E PATOGÊNICOS}

STEFANIA MARCIA DE OLIVEIRA SOUZA

ORIENTADORA: MÁRCIA DE AGUIAR FERREIRA

TESE DE DOUTORADO EM CIÊNCIAS ANIMAIS PUBLICAÇÃO: 174D/2016

BRASÍLIA-DF

DEZEMBRO DE 2016 


\title{
ESTUDO DA INTERFERÊNCIA DE SUBSTRATOS ORGÂNICOS NA AÇÃO DO OZÔNIO SOBRE MIICRORGANISMIOS DETEIRIORANTES, BENÉFICOS E PATOGENICOS
}

\author{
STEFANIA MARCIA DE OLIVEIRA SOUZA
}

TESE DE DOUTORADO SUBMETIDA AO PROGRAMA DE PÓS-GRADUAÇÃO EM CIÊNCIAS ANIMAIS, COMO PARTE DOS REQUISITOS NECESSÁRIOS À OBTENÇÃO DO GRAU DE DOUTOR EM CIÊNCIAS ANIMAIS.

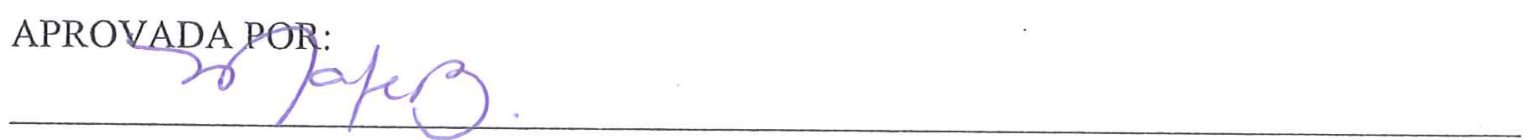

Márcia de Aguiar Ferreira, Profa. Dra. (Universidade de Brasília) - Orientadora

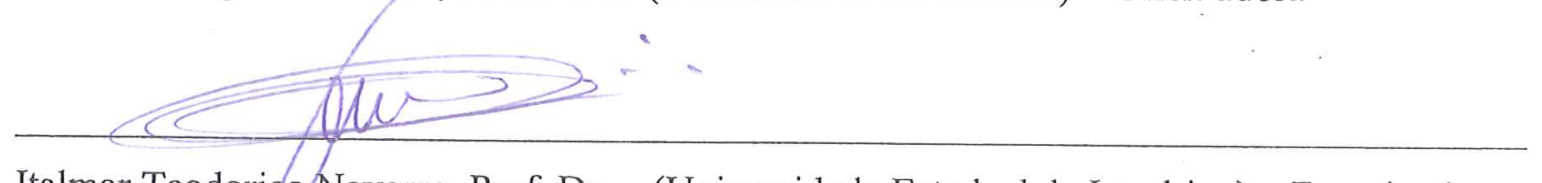

Italmar Teodorico/Navarro, Prof. Dr. - (Universidade Estadual de Londrina) - Examinador

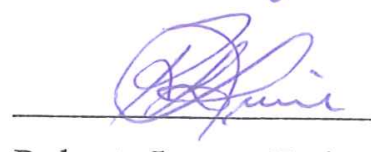

Roberta Lemos Freire, Profa. Dra.- (Universidade Estadual de Londrina) - Examinadora

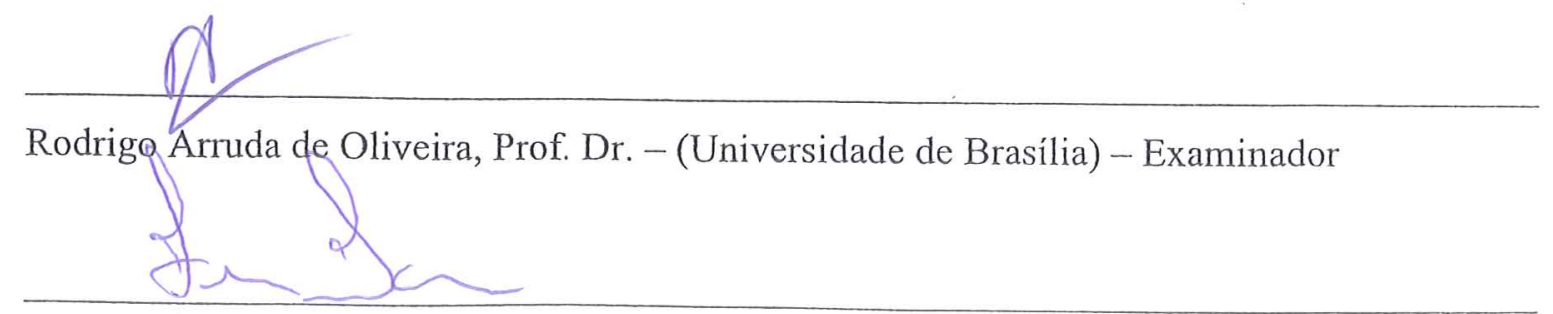

Fernando Araripe Gonçalves Torres, Prof. Dr. - (Universidade de Brasília) - Examinador

Brasília-DF, 16 de Dezembro de 2016. 
Ficha catalográfica elaborada automaticamente,

com os dados fornecidos pelo(a) autor(a)

Souza, Stefania Marcia de Oliveira

ESTUDO DA INTERFERÊNCIA DE SUBSTRATOS ORGÂNICOS NA AÇÃO

DO OZÔNIO SOBRE MICRORGANISMOS DETERIORANTES, BENÉFICOS

E PATOGÊNICOS / Stefania Marcia de Oliveira Souza; orientador Márcia de Aguiar Ferreira. -- Brasília, 2016.

$134 \mathrm{p}$.

Tese (Doutorado - Doutorado em Ciência Animal) -- Universidade de Brasília, 2016.

1. Microbiota do Leite. 2. Inocuidade dos alimentos. 3. matéria orgânica. 4. Lactobacillus sakei. 5. Escherichia coli. I. Ferreira, Márcia de Aguiar, orient. II. Título. 


\section{DEDICATÓRIA}

Dedico aos meus pais Luiz Carlos de Souza (in memoriam) e Gloria Maria de Oliveira Souza, meus exemplos de vida, honestidade e humildade que sempre me ensinaram e me apoiaram em toda minha caminhada profissional.

Ao meu esposo Felipe Matheus dos Santos pelo apoio e incentivo incondicional. Aos meus filhos Johnnathan Luiz e Derick Noah por serem meus motivos maiores a seguir adiante.

Aos meus irmãos Roger, Marcel e Fernanda pelos dias de descontração e por não me permitir desistir jamais. 


\section{AGRADECIMENTOS}

Nesses anos de doutorado foram muitas as pessoas que colaboraram e às quais espero poder transmitir toda minha eterna gratidão.

A Deus, em primeiro lugar, por permitir vencer mais esta etapa profissional, dando-me força e saúde.

Ao meu pai que lá do céu me manteve firme para conseguir concluir esta jornada. A minha amada mãe que me prestou toda solidariedade, me apoiando e me auxiliando com meus filhos para que eu pudesse me dedicar à pesquisa. Mãe muito obrigada!

Ao meu marido Felipe por simplesmente me amar dedicando sua paciência quando eu muitas vezes perdi a minha, sua atenção por me ouvir nos momentos de angústia, sua força e seu enorme carinho. Amo-te demais!

Aos meus filhos, irmãos, cunhadas, sobrinhos e amigos, que me incentivaram nesta trajetória e por sempre estarem presentes em minha vida! Amo vocês!

À minha orientadora Profa. Márcia de Aguiar Ferreira, que me confiou mais este trabalho e deu-me a oportunidade de realizá-lo, agradeço imensamente pelos ensinamentos, por toda a sua paciência e pelas conversas sempre construtivas. Ao Professor Ernandes Alencar pela colaboração incansável em vários finais de semanas dedicados a esta pesquisa e pelas conversas sempre agradáveis.

Aos companheiros do Laboratório de Análises de Leite e Derivados, Jaqueline, Emanuel, Sabrina e Kamila pela imensa colaboração na pesquisa, na organização dos materiais, pelas ideias, enfim por tudo.

Meu muito obrigado a todos vocês! 


\section{ÍNDICE}

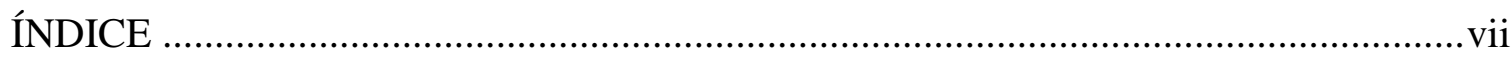

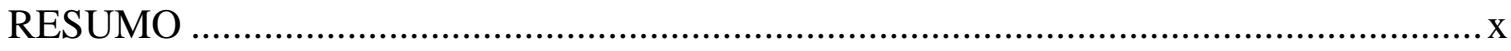

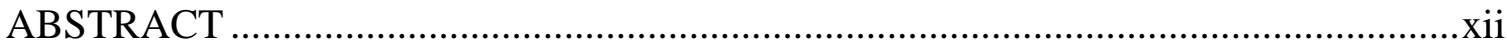

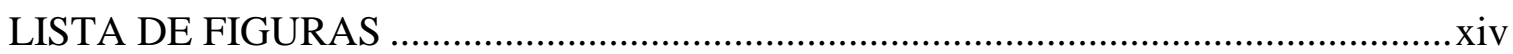

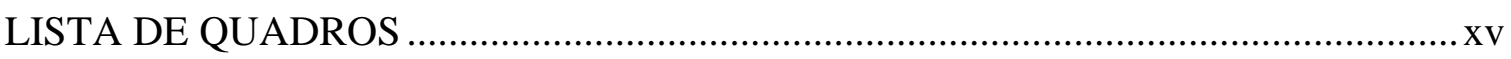

LISTA DE TABELAS ………………………………....................................

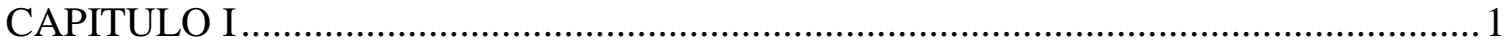

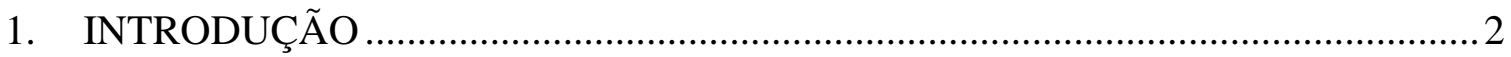

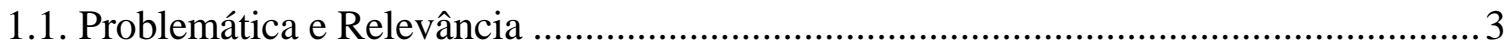

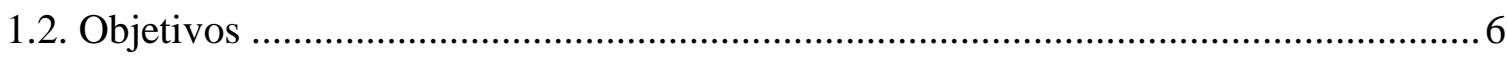

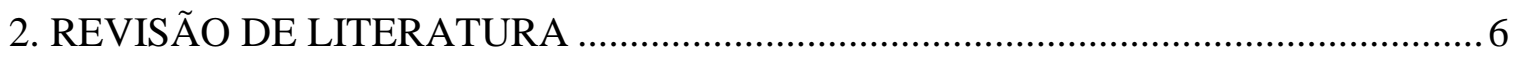

2.1. Principais microrganismos patogênicos veiculados por alimentos ............................... 6

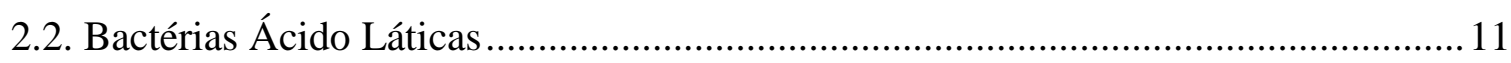

2.2.1. Gênero Lactobacillus e importância na indústria de alimentos................................. 13

2.3. Substratos para desenvolvimento microbiano …………………................................ 15

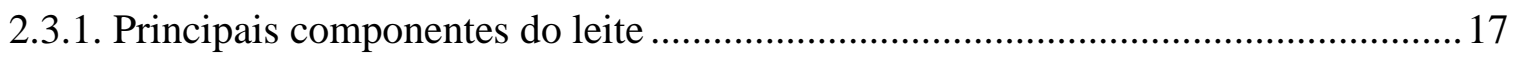

2.4. Biofilmes na indústria de alimentos e importância da higienização ............................ 19

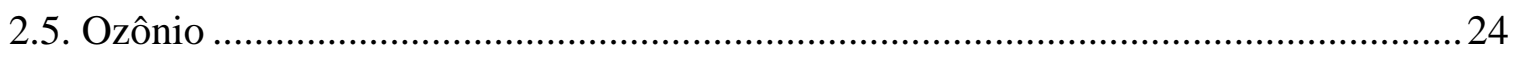

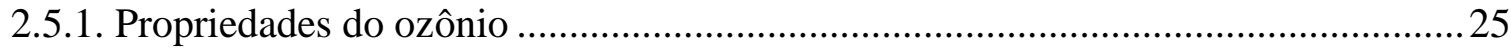

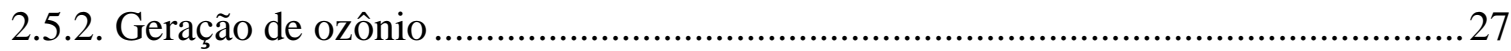

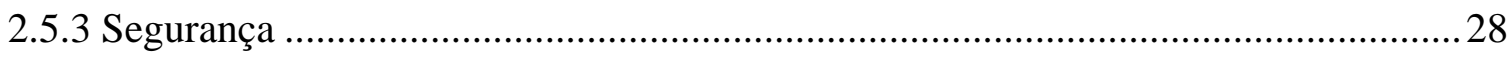

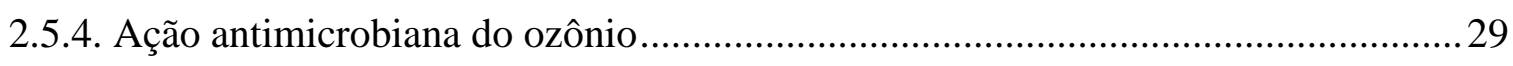

2.5.5. Utilização do ozônio na indústria de alimentos........................................................ 31 


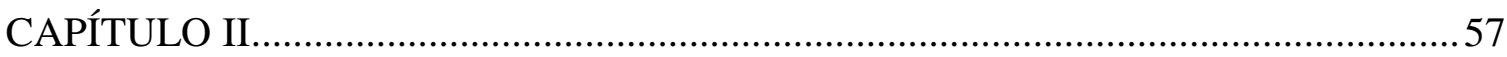

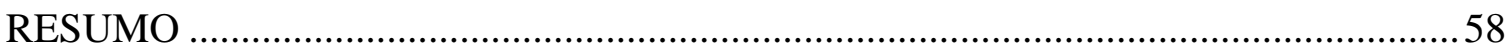

ORGANIC MATTER INTERFERENCE IN THE OZONE'S ACTION ON ESCHERICHIA COLI AND LACTOBACILLUS SAKEI ............................................59

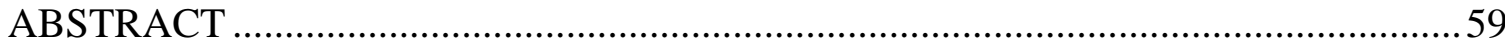

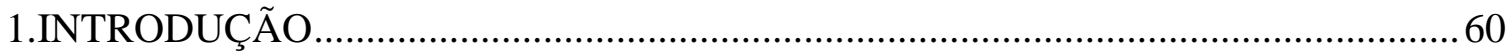

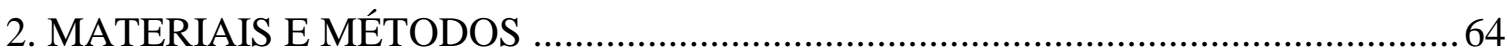

2.1. Local da pesquisa, origem das cepas e tratamento dos substratos .............................64

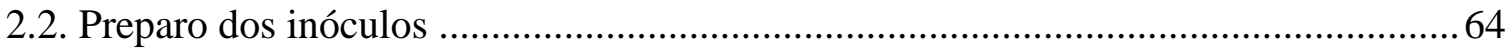

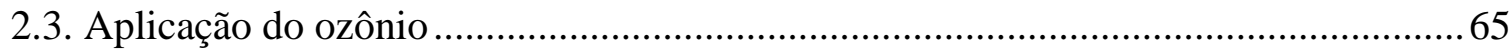

2.4. Binômios concentração de ozônio $x$ tempo de exposição .......................................... 65

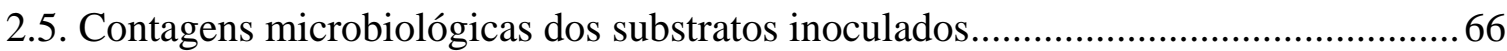

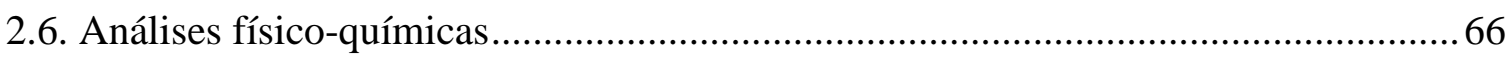

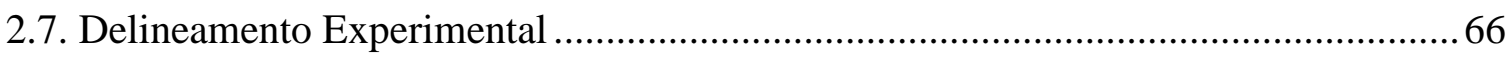

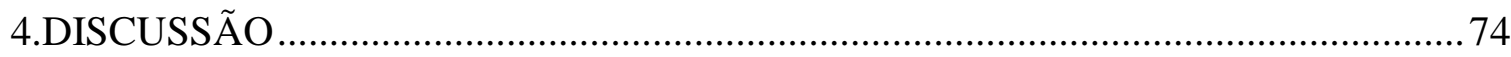

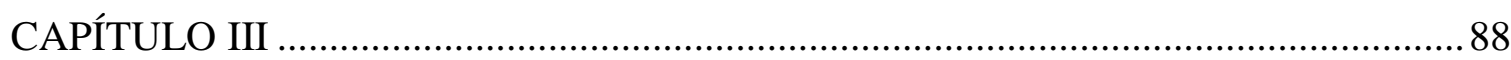

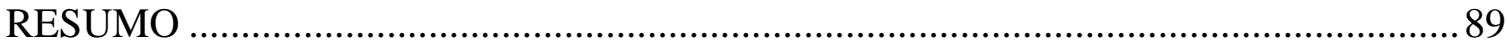

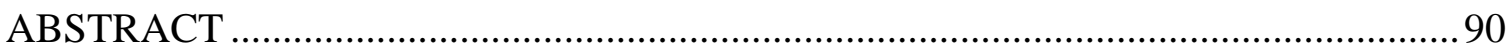

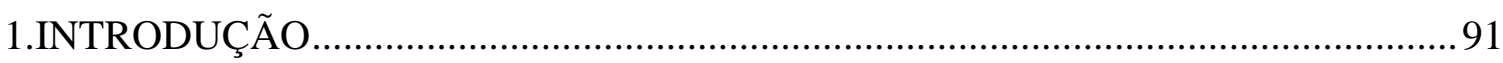

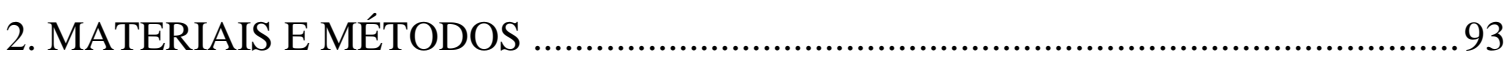

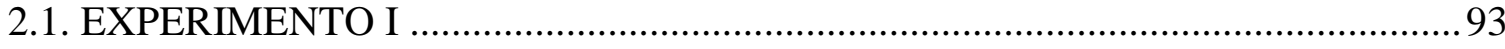

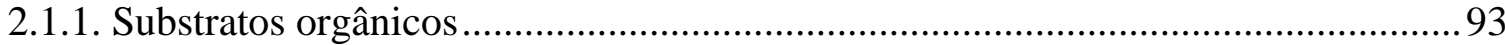

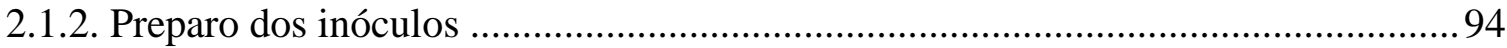

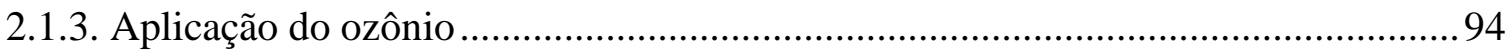

2.1.4. Binômios de concentração de ozônio x tempo de exposição ..................................95

2.1.5. Análises microbiológicas dos substratos inoculados.............................................95

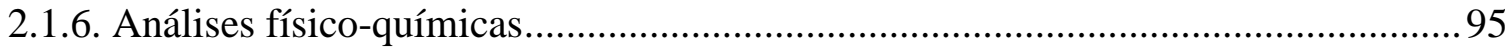

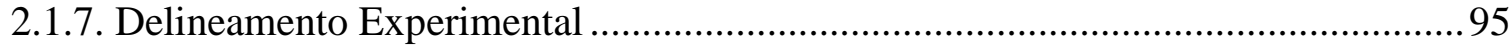

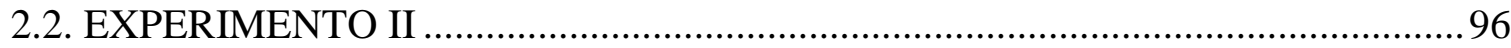

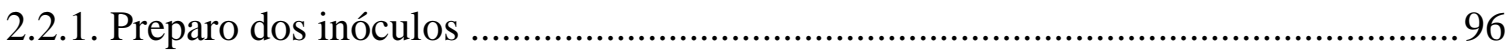

2.2.2. Obtenção do ozônio, tratamento da água destilada ozonizada e inóculos................96

2.2.3. Mensuração do ozônio residual na água................................................................. 97

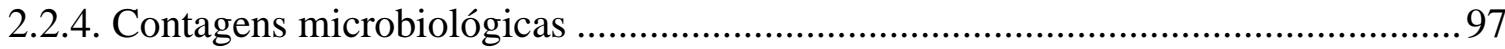

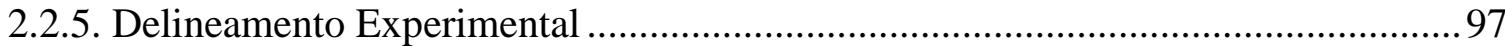




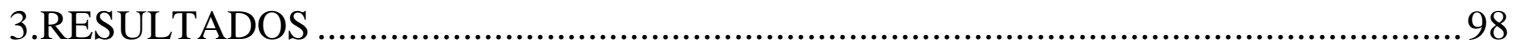

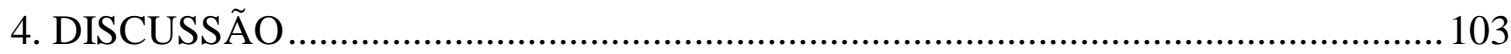

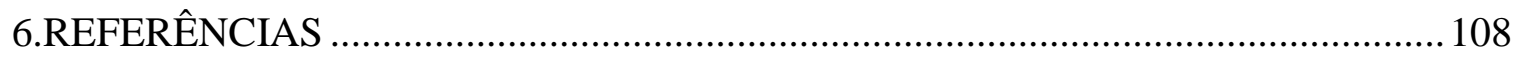

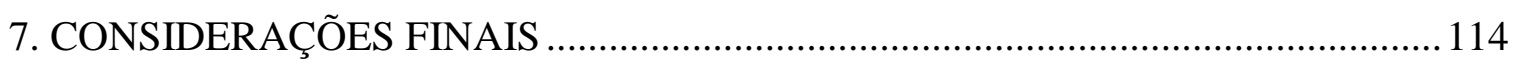

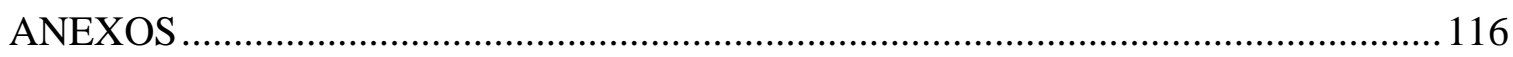




\title{
RESUMO
}

\section{ESTUDO DA INTERFERÊNCIA DE SUBSTRATOS ORGÂNICOS NA AÇÃO DO OZÔNIO SOBRE MICRORGANISMOS DETERIORANTES, BENÉFICOS E PATOGÊNICOS.}

\author{
Stefânia Márcia de Oliveira Souza ${ }^{1}$, Márcia de Aguiar Ferreira ${ }^{1,2}$ \\ ${ }^{1}$ Faculdade de Agronomia e Veterinária - UnB, DF, ${ }^{2}$ Laboratório de Análise de Leite e \\ Derivados - UnB.
}

A utilização do ozônio na indústria de alimentos é alvo de pesquisas desde que o composto foi considerado seguro por associações internacionais como a FDA (Food and Drug Administration), com efetiva ação contra bactérias Gram positivas e Gram negativas, fungos e vírus. Essa pesquisa foi conduzida em duas etapas que objetivaram avaliar a interferência de substratos orgânicos na ação do ozônio sobre microrganismos deteriorantes e benéficos, a eficácia do ozônio e da água ozonizada refrigerada sobre patogênicos. Na primeira adotaramse como substratos orgânicos, leites com diferentes composições (integral homogeneizado com lactose, integral homogeneizado sem lactose, desnatado homogeneizado com lactose, desnatado homogeneizado sem lactose integral sem homogeneização) que foram inoculados com cepas de Escherichia coli (ATCC® 11229TM) e Lactobacillus sakei subsp. sakei (ATCC ${ }^{\circledR} 15524^{\mathrm{TM}}$ ); também, avaliou-se a água como um substrato parâmetro de comparação. O gás ozônio foi utilizado nas concentrações de 21 e $31 \mathrm{mg} / \mathrm{L}$ por períodos de exposição de 0 , 5, 15 e 25 min. Na segunda etapa, foi avaliado o efeito da aplicação direta (gás) e indireta (água ozonizada) do ozônio sobre Escherichia coli O157:H7 (ATCC® 43890 ${ }^{\mathrm{TM}}$ ); na aplicação direta utilizou-se os mesmos substratos, concentrações de ozônio e períodos de exposição da primeira etapa. Para a obtenção da água ozonizada, a concentração utilizada do gás foi de $31 \mathrm{mg} / \mathrm{L}$ e o período de exposição de $15 \mathrm{~min}$; adotou-se um período de contato de 5 min do inóculo com a água ozonizada que era mantida estocada sob refrigeração $\left(7^{\circ} \mathrm{C} \pm 1^{\circ} \mathrm{C}\right)$ por $0 ; 0,5 ; 1,0 ; 1,5 ; 3,0$ e $24 \mathrm{~h}$. Em ambas as etapas o efeito do ozônio foi determinado por meio das contagens dos microrganismos inoculados, antes e após a ozonização. Para as contagens de E. coli utilizou-se o sistema Petrifilm ${ }^{\mathrm{TM}}$ EC; para contagens de Lb. sakei utilizou-se o ágar De Man Rogosa e Sharpe (MRS) e, para E. coli O157:H7 foi utilizado o ágar Violet Red Bile (VRB). Por fim, buscou-se observar possíveis alterações das características físico-químicas dos leites submetidos à ozonização. Aplicou-se o Delineamento Inteiramente Casualizado, com três repetições. Na primeira etapa verificou-se que a composição do substrato interfere na ação do ozônio sobre as contagens de $E$. coli e $L b$. sakei. Observou-se que as maiores reduções nas contagens desses microrganismos ocorreram quando em água e em leite desnatado homogeneizado sem lactose. Em água, tanto para E. coli quanto para $L b$. sakei, as reduções médias nas contagens foram maiores que 3 ciclos log, em todas as combinações de concentração do gás e período de exposição. Quando o substrato foi leite desnatado homogeneizado sem lactose, as reduções nas contagens de E. coli, independentemente do tempo, permaneceram entre 3,1 e 3,36 ciclos log, enquanto que para Lb. sakei, a maior redução foi de 1,49 ciclos log e na concentração de $31 \mathrm{mg} / \mathrm{L}$ por $25 \mathrm{~min}$. No substrato leite integral homogeneizado, as reduções na contagem de $L b$. sakei foram inferiores a 0,1 ciclo log. Na segunda etapa, também se constatou que a ação do ozônio sobre E. coli $\mathrm{O} 157: \mathrm{H} 7$ foi influenciada pela composição dos substratos. No leite desnatado homogeneizado sem lactose foram obtidas reduções de 1,53 e 1,54 ciclos log para períodos de exposição de $25 \mathrm{~min}$. nas concentrações de 21 e $31 \mathrm{mg} / \mathrm{L}$, respectivamente. Nos substratos leite integral homogeneizado com lactose e leite desnatado homogeneizado com lactose, as reduções nas contagens de E. coli $\mathrm{O} 157: \mathrm{H} 7$ foram inferiores a 0,40 ciclo log, em ambas as concentrações de ozônio e em todos os períodos de exposição ao gás. Já na avaliação da eficiência da água ozonizada sobre E. coli $\mathrm{O} 157: \mathrm{H} 7$ os resultados mostraram redução média 
de aproximadamente, 4,5 ciclos log em todos os ensaios realizados. Não foram observadas alterações significativas nas características físico-químicas nos diferentes leites submetidos à ozonização. Os resultados dessa pesquisa permitem concluir que substratos orgânicos gordura e lactose, como os principais componentes do leite, interferem na ação do ozônio sobre $E$. coli e E. coli $\mathrm{O} 157: \mathrm{H} 7$ diminuindo a sua eficácia como sanitizante e reforçando a necessidade de remoção adequada de matéria orgânica nos processos de limpeza. Por outro lado, as baixas reduções nas contagens de $L b$. sakei indicam que o seu desenvolvimento é pouco afetado pelo ozônio, quando inoculado em substratos orgânicos. A água ozonizada refrigerada por até $24 \mathrm{~h}$ é eficaz no controle de E. coli $\mathrm{O} 157: \mathrm{H} 7$, podendo representar uma alternativa a outros sanitizantes. E por fim, a aplicação de ozônio no leite, nas concentrações avaliadas, não causa alterações importantes nas características físico-químicas do leite de vaca de diferentes composições.

Palavras chaves: microbiota, leite, inocuidade dos alimentos, matéria orgânica, Lactobacillus sakei, Escherichia coli. 


\section{ABSTRACT \\ STUDY OF THE INTERFERENCE OF ORGANIC SUBSTRATES IN THE ACTION OF OZONE ON DETERIORATING, BENEFICIAL AND PATHOGENIC MICROORGANISMS}

The use of ozone in the food industry has been the subject of research since the compound was considered safe by international associations such as an FDA, with effective action against Gram-positive and Gram-negative bacteria, fungi and viruses. This research was conducted in two stages that aimed to evaluate an interference of organic substrates in the action of ozone on a deteriorating and beneficial microorganism and an efficacy of refrigerated ozonated water on pathogens. In the first stage, organic milk substrates (lactose homogenized homogenate, lactose-free homogenized skim milk, lactose homogenized skim milk, lactose-free homogenized skim milk and whole without homogenization) were used as organic substrates and were inoculated with strains of Escherichia coli 11229 TM) and Lactobacillus sakei subsp. Sakei (ATCC ${ }^{\circledR} 15524$ TM); Also, water was evaluated as a substrate parameter for comparison. Ozone gas was used at concentrations of 21 and $31 \mathrm{mg} /$ L for periods of exposure of $0,5,15$ and $25 \mathrm{~min}$. In the second stage, the effect of direct and indirect ozone application on Escherichia coli O157:H7 (ATCC ${ }^{\circ} 43890$ TM) was evaluated; the direct application consisted of applying the same substrates, ozone concentrations and exposure periods according to the first step. To obtain ozonated water, the gas concentration was $31 \mathrm{mg} / \mathrm{L}$ and the exposure period was 15 minutes. A 5-minute contact period was used to evaluate the efficacy of ozonated water stored under refrigeration $\left(7^{\circ} \mathrm{C} \pm 1^{\circ} \mathrm{C}\right)$ by $0 ; 0,5$; 1,$0 ; 1,5 ; 3,0$ and $24 \mathrm{~h}$ in the control of E. coli O157: H7. In both stages the ozone effect was determined by the counts of the inoculated microorganisms, before and after the ozonation. For the counts of E. coli the Petrifilm ${ }^{\text {TM }}$ EC system was used; For Lb. sakei counts. (MRS) and E. coli O157:H7, the Violet Red Bile agar (VRB) was used. Finally, it was possible to observe possible changes in the physical-chemical characteristics of the milks submitted to ozonization. A completely randomized design was used, with three replicates. In the first step it was found that the substrate composition produces effects on ozone action on E. coli and Lb. Sakei counts. It was observed that the greatest reductions in the counts of these microorganisms occurred when in water and skim milk homogenized without lactose. In water, for both $E$. coli and $L b$. sakei, mean counts reductions were greater than 3 log cycles in all combinations of gas concentration and exposure period. When the substrate was nonlactose homogenized skim milk, the reductions in E. coli counts, regardless of the time, remained between 3,1 and 3,36 log cycles, whereas for $L b$. Sakei, the largest reduction was $1,49 \log$ cycles and the concentration of $31 \mathrm{mg} / \mathrm{L}$ for 25 minutes. And when the substrates for homogenized whole milk, such as reductions in Lb. sakei count were less than 0,1 log cycle. In the second step, it was also found that an ozone action on E. coli O157:H7 was influenced by the composition of the substrates. In non-lactose homogenized skim milk, reductions of 1,53 and 1,54 log cycles were obtained for 25 minutes exposure periods. At concentrations of 21 and $31 \mathrm{mg} / \mathrm{L}$, respectively. On the substrates homogenized milk with lactose and skim milk homogenized with lactose, the reductions in the counts of E. coli O157: H7 were lower than $0,40 \log$ cycles, in both the concentration of ozone and in all periods of exposure to the gas. In the evaluation of the ozonated water efficiency on E. coli $\mathrm{O} 157: \mathrm{H} 7$ the results showed an average reduction of approximately 4,5 log cycles in all tests performed. No significant changes were observed in the physicochemical characteristics of the different milks submitted to ozonization. The results of this research allow us to conclude that organic substrates, such as the main components of milk, interfere with the action of ozone on E. coli, and E. coli O157:H7 decreasing its effectiveness as a sanitizing agent and reinforcing the need for 
adequate removal of organic matter cleaning processes. On the other hand, the low reductions in $L b$. sakei indicate that their development is poorly affected by ozone when inoculated on organic substrates. The refrigerated ozonated water for up to 24 hours is effective in the control of E. coli $\mathrm{O} 157: \mathrm{H} 7$, and may represent an alternative to other sanitizers. Finally, the application of ozone in milk, at the concentrations evaluated, does not cause important changes in the physical-chemical characteristics of cow's milk of different compositions.

Key words: milk, microbiota, food safety, organic matter, Lactobacillus sakei, Escherichia coli. 


\section{LISTA DE FIGURAS}

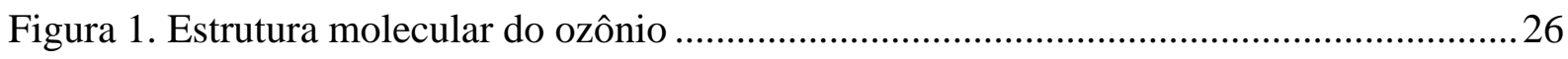

Figura 2. Geração do ozônio através do processo corona ......................................................28

Figura 3. Redução na contagem de Escherichia coli $\left(\log \mathrm{N}_{0} / \mathrm{N}\right)$ em leite com diferentes composições em função do período de ozonização................................................................... 69

Figura 4. Redução na contagem de Lactobacillus sakei $\left(\log \mathrm{N}_{0} / \mathrm{N}\right)$ em leite com diferentes composições nas concentrações de $21 \mathrm{mg} / \mathrm{L}$ (A) e $31 \mathrm{mg} / \mathrm{L}$ ( B) em função do tempo............73 Figura 5. Redução na contagem de Escherichia coli O157:H7 $\left(\log \mathrm{N}_{0} / \mathrm{N}\right)$ em leite com diferentes composições nas concentrações de $21 \mathrm{mg} / \mathrm{L}$ (A) e $31 \mathrm{mg} / \mathrm{L}$ (B) em função do período de exposição ao ozônio........................................................................................ 101 


\section{LISTA DE QUADROS}

Quadro 1. Principais propriedades dos gêneros de bactérias ácido láticas 12

Quadro 2. Solubilidade em água, facilidade de remoção e o efeito do calor dos principais resíduos em equipamentos de processamento em laticínios 21

Quadro 3. Comparação das características dos processos de cloração e de ozonização..........24

Quadro 4. Principais características físico-químicas do gás ozônio puro. ...............................26

Quadro 5. Agentes oxidantes e seus respectivos potenciais de oxidação...............................2 27

Quadro 6. Níveis apropriados de aplicação do ozônio. ...........................................................29 


\section{LISTA DE TABELAS}

Tabela 1. Resumo da análise de variância referente à redução nas contagens de Escherichia coli e de Lactobacillus sakei $\left(\log \mathrm{N}_{0} / \mathrm{N}\right)$ inoculadas em leite com diferentes composições ozonizados em diferentes combinações de concentração do ozônio e período de exposição ao gás.

Tabela 2. Valores médios referentes à redução na contagem de Escherichia coli (log $N_{0} / N$ ) em leite com diferentes composições ozonizados nas concentrações de 21 e $31 \mathrm{mg} / \mathrm{L}$ independente do período de exposição ao gás

Tabela 3. Equações de regressão ajustadas em função do tempo para redução na contagem de Escherichia coli $\left(\log \mathrm{N}_{0} / \mathrm{N}\right.$ ) em leite com diferentes composições em função do período de ozonização e seus respectivos coeficientes de determinação (R2).

Tabela 4. Valores médios referentes à redução na contagem de Lactobacillus sakei (log N0/N) em diferentes combinações de substrato $(S)$ e período de exposição $(P)$ nas concentrações $(C)$ de ozônio de 21 e $31 \mathrm{mg} / \mathrm{L}$.

Tabela 5. Valores médios referentes à redução na contagem de Lactobacillus sakei $\left(\log N_{0} / N\right)$ em diferentes combinações de concentração de gás $(C)$ e período de exposição $(P)$ em leite com diferentes composições

Tabela 6. Equações de regressão ajustados em função do período de ozonização ao ozônio para redução na contagem de Lactobacillus sakei $\left(\log \mathrm{N}_{0} / \mathrm{N}\right)$ em leite com diferentes composições e nas concentrações de 21 e 31 mg/L e seus respevtivos coeficientes de determinação...

Tabela 7. Resumo da análise de variância referente à redução na contagem de Escherichia coli O157:H7 ( $\log \mathrm{N}_{0} / \mathrm{N}$ ) em leite com diferentes composições ozonizados nas concentrações de 21 e 31 mg L-1, por períodos de 0, 5, 15 e 25 min..... 98

Tabela 8. Valores médios referentes à redução na contagem Escherichia coli 0157:H7 (log $\left.N_{0} / N\right)$ em diferentes combinações de substrato e Período de exposição $(P)$ nas concentrações $(C)$ do ozônio de 21 e $31 \mathrm{mg} / \mathrm{L}$ 99

Tabela 9. Valores médios referentes à redução na contagem Escherichia coli 0157:H7 $\left(\log \mathrm{N}_{0} / \mathrm{N}\right)$ em diferentes combinações de concentração do gás $(C)$ e Período de exposição $(P)$ em leite com diferentes composições 100

Tabela 10. Equações de regressão ajustadas da redução na contagem de Escherichia coli O157:H7 ( $\log \mathrm{N}_{0} / \mathrm{N}$ ) em função do período de exposição ao ozônio, em leite com diferentes composições nas concentrações de 21 e $31 \mathrm{mg} / \mathrm{L}$, e seus respectivos coeficientes de determinação 101

Tabela 11. Valores médios de concentração do ozônio dissolvido e da temperatura em água armazenada a $8^{\circ} \mathrm{C}$, por 24 horas 
CAPITULO I 


\section{INTRODUÇÃO}

O grande desafio atual que as indústrias de alimentos enfrentam é o desenvolvimento de tecnologias de controle da contaminação em plantas de processamento industriais. $\mathrm{O}$ aumento da demanda por tais tecnologias demonstra a necessidade de utilização de processos que propiciem segurança microbiológica na produção e proporcionem mínimas alterações físico-químicas e sensoriais dos produtos. Tais tecnologias de processamento/conservação não devem agredir o meio ambiente nem causar alterações indesejáveis nos produtos. As tecnologias aplicadas com este intuito são chamadas de "tecnologias não convencionais", "tecnologias emergentes", "tecnologias inovadoras", "tecnologias limpas", ou "tecnologias de baixo impacto ambiental" (SLONGO, 2008). Dentre estas tecnologias para sanitização, destaca-se o processo de ozonização.

De maneira geral, espera-se que os sanitizantes apresentem toxicidade e corrosividade baixas, sejam estáveis nas mais diversas condições de uso, possuam amplo espectro de ação antimicrobiana, destruam rapidamente os agentes e sejam aprovados pelos órgãos competentes como o Ministério da Saúde. Porém, não existe um único produto que apresente todas essas características, por isso é importante conhecer as propriedades de cada um que esteja disponível, para selecionar o mais adequado para cada aplicação específica (ANDRADE, 2008).

$\mathrm{O}$ ozônio $\left(\mathrm{O}_{3}\right)$ é um agente antimicrobiano, com reatividade elevada e decomposição espontânea em produtos não tóxicos (oxigênio). A ozonização tem sido utilizada na Europa para sanitizar água para o consumo humano. Outros usos comerciais incluem tratamento de piscinas, sanitização de galões de água, higienização de câmara-frias e equipamentos utilizados no processamento de alimentos, além da inativação da microbiota contaminante com resultados satisfatórios na inativação e eliminação de bactérias, fungos, vírus e protozoários (GOPAL et al., 2010; SILVA et al., 2011; CAVALCANTE et al., 2015; COUTO et al., 2016). 
A aplicação de ozônio tem sido avaliada em diversos produtos cárneos, derivados lácteos, aves, peixes, frutas e vegetais, e os resultados obtidos nas pesquisas afirmam que ocorre aumento da vida de prateleira dos produtos, e que o gás pode ser usado como sanitizante no processamento de alimentos. O nível de inativação varia com o $\mathrm{pH}$, temperatura e quantidade de matéria orgânica associadas as células, ou seja, sua eficácia esta diretamente relacionada ao tipo de substrato ao qual o microrganismo esta inserido (KIM et al., 1999; IBANOGLU, 2001; SHARMA e DEMIRCI, 2003; WU et al.; 2006; BIALKA e DEMIRCI 2007; NAJAFI e KHODAPARAST, 2009; TIWARI et al., 2009; O'DONNELL et al., 2012; COUTO et al., 2016).

A ozonização passou a ser utilizada no Brasil como alternativa aos métodos convencionais de pré-cloração e pré-aeração no tratamento de águas superficiais a partir de 1983 (LAPOLLI et al., 2003). Na área de alimentos, poucas pesquisas têm sido realizadas no país e ainda não existe legislação específica que oriente aplicações nesta área, embora seja eficiente e considerado mais seguro do que os demais sanitizantes comumente utilizados pela indústria de alimentos, pois não deixa resíduos capazes de alterar suas características organolépticas. Dentre suas aplicações destaca-se a desinfecção de instalações, equipamentos e embalagens, além de evitar formação de biofilmes microbianos (PASCHOALATO et al., 2008; LANITA e SILVA, 2008; CAVALCANTE et al., 2014).

\subsection{Problemática e Relevância}

As bactérias, bolores e leveduras são os microrganismos de maior destaque como agentes potenciais de deterioração e como eventuais patógenos ao homem. Na grande maioria das situações, as bactérias são os microrganismos numericamente predominantes, principalmente por apresentarem um tempo de geração bastante reduzido, serem capazes de utilizar uma diversidade de substratos e apresentarem ampla variação de comportamento dos diferentes gêneros frente a fatores ambientais (DE MESQUITA et al., 2014).

Em qualquer tipo de processamento industrial a manutenção das condições higiênico-sanitárias é um requisito essencial. Sabe-se que a carga microbiana contaminante do produto final é a somatória dos microrganismos presentes na matéria-prima e aqueles que se agregam ao produto ao longo das várias etapas do processo, principalmente em função do contato com superfícies e equipamentos mal higienizados, formação de biofilmes bacterianos, intensidade e condições de manuseio, qualidade da água e do ar, bem como fatores ambientais diversos (PARIZZI et al., 2004). 
A formação de biofilmes ocorre em virtude da deposição e adesão de microrganismos em uma superfície de contato, a qual se fixa, constitui uma matriz de exopolissacarídeos e iniciam seu crescimento. Seu desenvolvimento é diretamente relacionado à quantidade de nutrientes nestes locais e em relação à quantidade de líquidos. Sua formação é preocupante devido sua potencialidade em resistir a tratamentos antimicrobianos e à sanitizantes, além de causar deterioração, perda da qualidade ou veiculação de patógenos (KASNOWSKI et al., 2010).

Dentre os microrganismos que podem participar de processos de formação de biofilmes e gerar problemas de saúde pública ou de ordem econômica, destacam-se: Pseudomonas aeruginosa, Pseudomonas fragi, Pseudomonas fluorescens, Micrococcus sp. e Enterococcus faecium. Como exemplos de patogênicos pode-se citar: Listeria monocytogenes, Yersinia enterocolitica, Salmonella thyphimurium, Escherichia coli O157:H7, Staphylococcus aureus e Bacillus cereus (PARIZZI et al., 2004).

Apesar dos recentes avanços tecnológicos e científicos, principalmente na indústria de laticínios, observa-se a ocorrência de enfermidades de origem alimentar devido à ingestão de alimentos contaminados por microrganismos patogênicos contidos nos produtos, que podem ser provenientes do contato com biofilmes existentes na planta de processamento com sanitização realizada de forma ineficaz (MEDONLINE, 2008).

A sanitização é um conjunto de procedimentos higiênico-sanitários que visa garantir a obtenção de superfícies, equipamentos e ambientes com características adequadas de limpeza e baixa carga microbiana residual. A procura de novos métodos de diminuição de microrganismos continua a ser um assunto relevante nos nossos dias. Embora os métodos tradicionais de desinfecção sejam intensivamente usados pela indústria alimentar, eles são também quimicamente intensivos e estão associados a vários aspectos negativos, incluindo a promoção do fenômeno de resistência cruzada a outros agentes antimicrobianos (OLIVEIRA et al., 2010).

De acordo com Pirani (2011) uma alternativa às técnicas de sanitização tradicionais seria a aplicação de ozônio na redução da população de E. coli O157:H7 e Salmonella spp. Novak e Yuan (2003) relatam que patógenos que sobrevivem à ozonização apresentam-se menos propensos a colocar em risco a segurança alimentar do que patógenos sobreviventes a tratamentos térmicos subletais.

O ozônio tem uma meia-vida maior no estado gasoso do que em solução aquosa. Apresenta rápida degradação em água sendo ainda mais rápida quando em soluções impuras, ou seja, aquelas que contem duas ou mais substâncias diferentes (GUZEL-SEYDIM 
et al., 2004). Quando comparado a outros agentes oxidantes, o ozônio destaca-se pelo elevado potencial de oxidação $(2,07 \mathrm{mV})$ sendo o segundo mais poderoso agente oxidante, superado apenas pelo flúor (3,06 mV) (GUZEL-SEYDIM et al., 2004; SILVA et al., 2011). A inativação das bactérias pelo ozônio é um processo complexo, por agir sobre numerosos componentes celulares, incluindo proteínas, lipídios insaturados e enzimas respiratórias nas membranas celulares, peptideoglicanos dos envelopes celulares, enzimas e ácidos nucleicos no citoplasma, proteínas e peptideoglicano das paredes de esporos e cápsulas virais. Alguns autores concluíram que o ozônio molecular é o principal inativador de microrganismos, enquanto outros enfatizam que a atividade antimicrobiana é realizada pelos subprodutos de decomposição do ozônio tais como ' $\mathrm{OH},{ }^{\circ} \mathrm{O}_{2}$ - e $\mathrm{HO}_{3}{ }^{\circ}$ (PIRANI, 2011).

Santos (2013) observou a ação de ozônio na redução de microrganismos aeróbios mesófilos e características físico-químicas do leite, verificando redução de aproximadamente 1 ciclo log quando aplicada a concentração de $15 \mathrm{mg} / \mathrm{L}$ durante 15 minutos e, de 5 e $10 \mathrm{mg} / \mathrm{L}$ por 30 minutos. Nas análises físico-químicas o leite após ozonização apresentou redução de gordura, extrato seco desengordurado, lactose, densidade e proteína no binômio $18 \mathrm{mg} / \mathrm{L}$ por 10 minutos.

De acordo com Silva et al. (2011), a desvantagem da utilização de ozônio como desinfetante é a sua instabilidade. O grande desafio é prever como o ozônio reage com a matéria orgânica; o gás pode oxidar o composto, ou espontaneamente, decompor-se em oxigênio e radicais livres. Os mecanismos de decomposição do ozônio são processos complexos, que dependem de fatores como os tipos de radicais formados em solução e o tipo de matéria orgânica presente. Portanto, é difícil generalizar que uma dada concentração particular de ozônio num determinado percentual será efetiva para inibição dos microrganismos presentes nos produtos alimentícios (LANGLAIS et al., 1991).

Tendo em vista o exposto e a importância dos temas abordados, consideramos necessárias mais pesquisas que avaliem a ação do ozônio sobre os diversos microrganismos que podem ser veiculados por alimentos e, a influência da matéria orgânica, que pode estar presente em alimentos ou mesmo em equipamentos de processamento, na ação desse gás. Dessa forma, esse estudo buscou avaliar a interferência de compostos orgânicos na ação do ozônio sobre o desenvolvimento de microrganismos patogênicos, deteriorantes e benéficos artificialmente inoculados em leites com diferentes composições e em água, a fim de gerar mais dados sobre a sua a eficácia como sanitizante e ampliar a sua utilização na indústria de alimentos. 


\subsection{Objetivos}

\section{Objetivo geral}

- Avaliar a interferência de substratos orgânicos na ação do ozônio sobre o desenvolvimento de microrganismos deteriorantes, benéficos e patogênicos.

\section{Objetivos específicos}

- Analisar a interferência da gordura e da lactose utilizados como substratos orgânicos, na ação do ozônio sobre Escherichia coli ATCC 11229 ${ }^{\mathrm{TM}}$ e Lactobacillus sakei ATCC $15521^{\mathrm{TM}}$.

- Avaliar os efeitos da aplicação direta e indireta de ozônio sobre o desenvolvimento de Escherichia coli O157:H7 (ATCC® 43890 ${ }^{\mathrm{TM}}$ ) inoculada em diferentes substratos orgânicos e em água.

- Verificar o efeito da ozonização sobre os principais componentes do leite de vaca.

\section{REVISÃO DE LITERATURA}

\subsection{Principais microrganismos patogênicos veiculados por alimentos}

Os agentes etiológicos causadores de doenças e que podem ser veiculados por alimentos representam problemas de saúde coletiva em qualquer parte do mundo, especialmente nos países em desenvolvimento como o Brasil. A severidade varia muito e as fontes mais comuns de infecções são hambúrgueres, "fast foods" e alimentos de "selfservices", que são mais vulneráveis a uma série de riscos de contaminação por microrganismos, o que pode ser atribuído ao preparo rápido, manipulação e procedimentos inadequados durante o processamento e exposição. Dentre os principais microrganismos que podem ser veiculados por alimentos destacam-se Salmonella spp., Listeria monocytogenes, Staphylococcus aureus, Escherichia coli, Brucella spp. e Mycobacterium (LIMA e OLIVEIRA, 2005).

Salmonella spp. são bactérias patogênicas importantes para a indústria de alimentos sendo um dos microrganismos mais significativos causadores de infecção alimentar (SIQUEIRA et al., 2003). São patógenos intracelulares que invadem a mucosa do trato intestinal, e são transmitidas de forma fecal-oral aos seres humanos principalmente através da 
água, da carne, dos ovos e dos produtos das aves domésticas contaminados. A infecção por Salmonella spp. é uma doença gastrintestinal, sendo a mais frequente transmitida dos animais aos seres humanos (FERRETTI et al., 2001; RIYAZ-UHASSAN et al., 2004).

Os membros do gênero Salmonella são causas principais de infecção alimentar no mundo inteiro. Os sorotipos de Salmonella entérica são os agentes bacterianos primários responsáveis pelas manifestações de doença gastrintestinal humana. Entre os diferentes sorotipos, Salmonella Typhimurium e Salmonella Enteritidis são de importância clínica particular (REIS et al., 2015).

Listeria spp. é um bacilo Gram positivo, aeróbico e facultativamente, anaeróbico, não formador de esporos, catalase positiva, oxidase negativa, sendo a faixa ótima de $\mathrm{pH}$ para o seu crescimento, de 6 a 8, porém pesquisas realizadas demonstraram seu crescimento quando em faixas de $\mathrm{pH}$ que variaram de 4,1 até 9,6, sendo capazes também, de crescer em diferentes temperaturas, tempos de incubação e concentrações salinas.

As espécies patogênicas para o homem e animais são $L$. monocytogenes e $L$. ivanovii (2) sendo atualmente descritas 13 espécies apatogênicas: L. innocua, L. welshimeri, L. grayi, L. seeligeri, L. rocourtiae, L. marthii, L. weihenstephanensis, L. fleischmannii, L. floridensis, L. aquatica, L. cornellensis, L. grandensis, e L. riparia (STEA et al., 2015).

A principal via de transmissão é o consumo de alimentos contaminados devido à habilidade de L. monocytogenes de sobreviver em condições de estresse e formar biofilmes em equipamentos e utensílios de plantas de processamento de alimentos, produzidos por uma ampla variedade de materiais, como aço inoxidável, plástico e vidros (BARROS et al., 2007; SCHMID et al., 2009, ZHU et al., 2012; COLAGIORGI et al., 2016). A listeriose na forma invasiva é caracterizada por apresentar quadros graves e alta taxa de mortalidade em indivíduos imunocomprometidos, crianças, idosos e gestantes (VÁZQUEZ-BOLAND et al., 2001; PAILLARD et al., 2003, LECUIT, 2007; ANDRADE et al., 2014). A ocorrência de surtos de listeriose de origem alimentar tem sido relatada desde 1981, sendo que diversos alimentos, de origem animal e de origem vegetal, estão envolvidos (FLEMING et al., 1985, LINNAN et al., 1988; SCHLECH et al., 1993; NG e SEAH., 1995; CORDANO e ROCOURT, 2000; BARBALHO et al., 2005; PIETA et al., 2015; RIETBERG et al., 2016).

Mycobacterium tuberculosis é o agente etiológico da tuberculose humana, considerada a principal causa de morte em adultos por um único agente infeccioso, sendo responsável por $26 \%$ das mortes passíveis de prevenção no mundo. Não se conhece a proporção de casos de tuberculose causada por Mycobacterium bovis (CASANOVA e ABEL, 2002, HUSSIEN e MAHROUS, 2016). 
As formas de transmissão do M. bovis do gado para os seres humanos se dá diretamente pela via aerógena, mediante a inalação do $M$. bovis e indiretamente, pelo consumo de leite e produtos lácteos não pasteurizados, e, além disso, o bovino elimina o bacilo no corrimento nasal, nas fezes, urina, nas secreções vaginais e uterinas e pelo sêmen. Diferente do que muitos acreditam a carne bovina, em via de regra, não pode ser apontada como fonte de infecção para a tuberculose humana, desde que passada por cocção, pois é raro o encontro do bacilo na musculatura. Porém para evitar algum problema a inspeção sanitária faz a condenação parcial ou total das carcaças, que conforme o caso é feito, pois a carne pode ser contaminada com secreções, fezes ou conteúdo dos granulomas formados (PARDO 2007; ZARDEN et al., 2013).

O gênero Staphylococcus é constituído de 40 espécies e 24 subespécies (MURRAY, 2010). A morfologia típica do gênero é classificada em cocos apresentando diâmetro médio de $1 \mu \mathrm{m}$ e que tendem a se agrupar em arranjos semelhantes a cachos de uva, apresenta necessidade nutricional complexa. São bactérias móveis, não formadoras de esporos, anaeróbicas facultativas, catalase-positiva, oxidase-negativos e podem produzir a enzima coagulase, sendo estas potencialmente patogênicas, dentre elas, S. aureus, $S$. intermedius e S. hyicus (HARRIS, 2002; QUINN et al., 2005, JAY, 2005; BECKER et al., 2015).

De acordo com Quinn et al. (2005), os animais podem desenvolver a mastite estafilocócica bovina, a piemia pelo carrapato em cordeiros, a botriomicose em equinos e infecções supurativas em cães e gatos. A mastite contagiosa exerce importância, principalmente, em dois aspectos: economia da atividade leiteira e saúde pública.

Trabulsi (2008) relata que as manifestações clínicas causadas por S. aureus em humanos podem ser divididas em três tipos: infecções superficiais, como abscessos cutâneos; infecções sistêmicas, como bacteremia e endocardite; intoxicações como a síndrome do choque tóxico e intoxicação alimentar. A intoxicação se desenvolve em pessoas que ingerem alimentos preparados ou armazenados de maneira imprópria. A severidade da doença depende da quantidade de alimento ingerido, da quantidade da toxina e do estado geral da saúde da vítima. A quantidade de toxina necessária para provocar intoxicação varia entre 20 e 100 ng e a doença só ocorre caso haja ingestão da toxina pré-formada no alimento, pois a bactéria, quando ingerida, não produz a toxina. É uma das principais causas de bacteremia tendo como principais sintomas: vômitos, diarreia, dor abdominal e náuseas podendo causar encocardite infecciosa e infecção osteoarticular (SCHELIN et al., 2011; MURRAY, 2010; TONG et al., 2015). 
A brucelose é uma enfermidade infectocontagiosa, de caráter zoonótico e ampla distribuição mundial. A enfermidade acomete uma ampla variedade de espécies de mamíferos terrestres e marinhos, incluindo o homem que é considerado um hospedeiro acidental, e causando a doença como febre ondulante, febre do Mediterrâneo ou febre de Malta. A doença, nos animais domésticos, é causada por bactérias do gênero Brucella, sendo identificadas como Brucella melitensis, B. abortus, B. suis, B. ovis e B. canis, destacando-se a Brucella abortus, que acomete principalmente os bovinos, podendo também causar doença no homem (De PAULA et al., 2015).

Nos seres humanos a brucelose é classificada como enfermidade ocupacional para pessoas que lidam diretamente com animais ou com seus produtos, como por exemplo, fazendeiros, médicos veterinários, magarefes, açougueiros e trabalhadores da indústria de laticínios. O homem se infecta naturalmente pelo contato com produtos abortados, secreções vaginais, lóquios placentários e outras secreções contaminadas, além do consumo de leite cru ou derivados não pasteurizados, sendo esta última considerada a forma de contaminação principal dos seres humanos. A pasteurização do leite elimina o patógeno e consiste de prática fundamental para garantir a saúde do consumidor e a qualidade de vários produtos alimentícios (SANTOS et al., 2013).

O gênero Escherichia é composto por cinco espécies: E. coli, E. blattae, E. fergusonnii, E. hermanniie E. vulneris; sendo E. coli um dos principais componentes da família Enterobacteriaceae. Esses microrganismos estão presentes na microbiota intestinal de humanos e animais, bem como em ambientes domésticos, no solo, na água e em plantas. São bactérias não formadoras de esporos, Gram negativas, anaeróbicas facultativas, oxidasenegativas e capazes de fermentar a glicose com formação de gás (KUHNERT et al., 2000; BOOP e SAUDERS, 2003, RIBEIRO et al., 2006, LARA 2016).

E. coli pode causar uma variedade de doenças, incluindo diarreia, disenteria, síndrome hemolítica-urêmica, infecções do trato urinário, septicemia, pneumonia e meningite (KAPER et al., 2004). Sua capacidade patogênica tem sido associada ao fato de diferentes linhagens de E. coli terem adquirido diferentes genes de virulência (KUHNERT et al., 2000, PEREIRA et al., 2016).

Com base nas características de patogenicidade, no efeito em certas culturas de células e nos grupos sorológicos são reconhecidos nove grupos de E. coli virulentos (patotipos): E. coli enteroagregativa (EaggEC), E. coli enterohemorrágica (EHEC), E. coli enteroinvasiva (EIEC), E. coli enteropatogênica (EPEC), E. coli enterotoxigênica (ETEC) e $E$. coli que adere difusamente (DAEC) E. coli uropatogênica (UPEC), E. coli de meningite 
neonatal (NMEC), E. coli patogênica para aves (APEC) (SILVA, 2008, PEREIRA et al., 2016).

Nos Estados Unidos da América (EUA), cepas de E. coli produtoras de verotoxinas (VT) e a EHEC foram causadoras de surtos de doença associada à ingestão de hambúrguer mal-cozido ou mesmo de leite cru. Estes agentes produzem toxinas semelhantes à toxina Shiga, que são responsáveis pela Colite Hemorrágica $(\mathrm{CH})$, citada pela primeira vez em 1983 por Riley et al. (apud NATARO e KAPER,1998). Crianças podem apresentar dores abdominais, diarreia aquosa seguida de diarreia sanguinolenta com pouca ou nenhuma febre. Estes sinais clínicos foram associados a casos mais graves como a Síndrome Urêmica Hemolítica, caracterizada pela presença de sangue na urina, insuficiência renal e trombocitopenia ocasionada por ação de toxina que afeta os rins (KARMALI, 1989). Vários sorotipos de VTEC (E. coli verotoxigênica) são classificados como EHEC destacando-se O26:H11, O111:H8, O118:H16, O145:H28; O55:H7, O113:H21 e principalmente O157:H7 relatada em grandes surtos e doenças graves, tais como colite hemorrágica $(\mathrm{CH})$ e síndrome hemolítica urêmica (SHU), potencialmente letais (NATARO e KAPER,1998, FREITAS et al., 2016).

Pesquisadores, manipulando cepas mutantes, estudaram a função do gene eaeA de E. coli O157:H7 e seu produto, a intimina, conforme relatam Doyle et al. (1991). Os estudos demonstram que o gene eaeA é necessário para a aderência deste microrganismo aos enterócitos e células de linhagens, presentes em várias cepas produtoras de VTs, particularmente naquelas associadas com doenças em humanos (FUKUSHIMA et al., 2000). Outros fatores de patogenicidade são também importantes para o desenvolvimento da doença (NATARO e KAPER, 1998). Várias evidências indicam existência de duas famílias de citotoxinas chamadas VT1/VT2, estas são codificadas por bacteriófagos lisogênicos, estão associadas com doenças em humanos e possuem a mesma ação sobre células Vero, mas diferem em sua toxicidade em camundongos (FUKUSHIMA et al., 2000).

Este microrganismo também foi associado a sinais clínicos menos severos como diarreias brandas e foi relatado em diversos surtos de doenças de origem alimentar em países desenvolvidos, associadas ao consumo de alimentos de origem animal, principalmente leite não pasteurizado e hambúrguer no qual a carcaça pode sofrer contaminação durante o abate do animal no frigorífico (SILVEIRA et al., 1999).

Produtos alimentares de origem animal são, portanto, os maiores causadores de infecções em seres humanos. Em países como EUA a ingestão de hambúrgueres que não foram submetidos a tratamento térmico eficiente, é causa importante na ocorrência de doença 
alimentar. Esta contaminação está associada a não higienização das mãos do manipulador. Surtos foram relatados devido ao consumo de maionese, sucos de frutas não pasteurizados, carne moída, cachorro quente e suco de maçã (AL-GALLAS et al., 2006; FORTUNA et al., 2013).

\subsection{Bactérias Ácido Láticas}

As bactérias ácido láticas (BALs) são descritas como microrganismos Gram positivos, geralmente imóveis, desprovidos de citocromos e tem preferência por condições anaeróbias, mas são aerotolerantes, fastidiosos, ácido-tolerantes e estritamente fermentativos, produzem ácido lático como produto principal (STILES e HOLZAPFEL, 1997). Estes não formam esporos, são catalase, oxidase e gelatinase negativos, morfologias de cocos ou bastonetes, não redução de nitrato a nitrito e incapacidade de utilizar o lactato (HASSAN e FRANK, 2001; CARR et al., 2002). Contudo, podem ocorrer exceções como algumas estirpes serem produtoras de pseudocatalase (AXELSSON, 1993; HOLZAPFEL e WOOD, 1995) ou serem catalase positivas e apresentarem cadeia de citrocromos quando em meios contendo hematina ou compostos similares (AXELSSON, 1993; INÊS et al., 2008, SABO et al., 2014).

Os principais gêneros de BALs são: Lactobacillus, Lactococcus, Leuconostoc, Oenococcus, Pediococcus, Streptococcus, Tetragenococcus, Aerococcus, Carnobacterium, Enterococcus, Vagococcus e Weissella (HUTKINS, 2006). Embora o gênero Bifidobacterium não pertença filogeneticamente ao grupo das BALs, possui determinadas propriedades fisiológicas e bioquímicas típicas destas bactérias. Portanto, por razões práticas e tradicionais, bifidobactérias são ainda consideradas uma parte do grupo das BALs (STILES e HOLZAPFEL, 1997; VASILJEVIC e SHAH, 2008; SIAMANSOURI et al., 2013).

Essas bactérias podem utilizar duas vias metabólicas de carboidratos: a homofermentativa e a heterofermentativa. Na rota homofermentativa, mais de $90 \%$ da fonte de carbono é convertida exclusivamente em ácido lático, pela via de glicólise EmbdenMeyerhof-Parnas. Por outro lado, a via heterofermentativa resulta em quantidades equimolares de ácido lático, ácido acético, etanol e dióxido de carbono (LIU, 2003, PALACIUS et al., 2014). A classificação está baseada na morfologia celular, na rota metabólica utilizada para fermentar a glicose, no desenvolvimento em diferentes temperaturas, na configuração do ácido lático produzido e na capacidade de crescimento em altas concentrações salinas (RIVERA-ESPINOZA e GALLARDO-NAVARRO, 2010), conforme apresentado no Quadro 1. 
Quadro 1. Principais propriedades dos gêneros de bactérias ácido láticas

\begin{tabular}{|c|c|c|c|c|c|c|c|c|c|}
\hline \multirow[t]{3}{*}{ Gênero } & \multirow[t]{3}{*}{ Morfologia celular } & \multirow[t]{3}{*}{ Rota metabólica } & \multicolumn{6}{|c|}{ Crescimento } & \multirow{3}{*}{$\begin{array}{c}\text { Isômero do ác. } \\
\text { lático }\end{array}$} \\
\hline & & & \multicolumn{2}{|c|}{$\mathbf{T}^{\circ} \mathbf{C}$} & \multicolumn{2}{|c|}{$\mathrm{NaCl}$} & \multicolumn{2}{|c|}{ pH } & \\
\hline & & & 10 & 45 & 6,5 & 18 & 4,4 & 9,6 & \\
\hline Lactobacillus $(\mathrm{Lb})$ & Bacilo & Homo/Heterofermentativo & \pm & \pm & \pm & - & \pm & - & $\mathrm{D}, \mathrm{L}, \mathrm{D} / \mathrm{L}$ \\
\hline Lactococcus (Lac) & Cocos & Homofermentativo & + & - & \pm & - & \pm & - & $\mathrm{L}$ \\
\hline Leuconostoc $(L)$ & Cocos & Heterofermentativo & + & - & \pm & - & \pm & - & $\mathrm{D}$ \\
\hline Oenococcus $(O)$ & Cocos & Heterofermentativo & + & + & \pm & - & \pm & - & $\mathrm{D}$ \\
\hline Pediococcus $(P)$ & Cocos (tetrade) & Homofermentativo & \pm & \pm & \pm & - & + & - & $\mathrm{D}, \mathrm{L}, \mathrm{D} / \mathrm{L}$ \\
\hline Streptococcus $(\mathrm{St})$ & Cocos & Homofermentativo & - & + & - & - & - & - & $\mathrm{L}$ \\
\hline Tetrogenococcus $(T)$ & Cocos (tetrade) & Homofermentativo & + & - & + & + & - & + & $\mathrm{L}$ \\
\hline Aerococcus $(A)$ & Cocos (tetrade) & Homofermentativo & + & - & + & - & - & + & $\mathrm{L}$ \\
\hline Carnobacterium $(C)$ & bacilos & Heterofermentativo & + & - & - & - & - & - & $\mathrm{L}$ \\
\hline Enterococcus $(E)$ & bacilos & Homofermentativo & + & + & + & - & + & + & $\bar{L}$ \\
\hline Vagococcus $(V)$ & bacilos & Homofermentativo & + & - & - & - & \pm & - & $\mathrm{L}$ \\
\hline Weissella $(W)$ & bacilos & Heterofermentativo & + & - & \pm & - & \pm & - & $\mathrm{D}, \mathrm{L}, \mathrm{D} / \mathrm{L}$ \\
\hline
\end{tabular}

Legenda: (+) crescimento positivo; (-) crescimento negativo; $( \pm)$ crescimento fraco; D- lactato; Llactato, D/L-lactado. Fonte: HUTKINS (2006).

BALs são microrganismos altamente exigentes, ou seja, seu habitat natural é representado por ambientes nutricionalmente ricos como matérias-primas de origem animal e vegetal, produtos fermentados e mucosas do trato gastrointestinal (TGI), respiratório e urogenital do homem e animais (SETTANNI e MOSCHETTI, 2010). Estes têm capacidade limitada de biossíntese (KLAENHAMMER et al., 2005), alto requerimento em fonte de carbono e nitrogênio (SALMINEN e VON WRIGHT, 1998) natureza anaeróbia ou aerotolerante (CARR et al., 2002). A importância das BAL's na indústria alimentícia deve-se a sua capacidade de transformar açúcares em acido lático, etanol, e outros metabólitos. Estes compostos podem alterar as características do produto através da diminuição do $\mathrm{pH}$ e por criar condições desfavoráveis para a multiplicação de microrganismos potencialmente patogênicos, tanto nos alimentos quanto na microbiota intestinal humana (RIVERA-ESPINOZA e GALLARDO-NAVARRO, 2010).

Estão envolvidas em diferentes processos fermentativos, incluindo fermentação malolática de vinhos (LIU, 2003; ROJO-BEZARES et al., 2006), produção de queijos, embutidos fermentados, legumes em conserva, iogurte entre outros alimentos. As BALs também têm sido utilizadas na fabricação de produtos biológicos e químicos, incluindo biopolímeros (Leuconostoc spp.), enzimas (Lb. brevis), etanol e ácido lático (Lb. casei, Lb. 
lactis, Lb. delbrueckii, Lb. brevis), além de compostos aromáticos e substâncias antimicrobianas, como as bacteriocinas (INÊS, 2007, GARCIA-ZAPATA, 2016).

A estes microrganismos são atribuídas propriedades nutritivas, medicinais e terapêuticas em virtude de sua ação benéfica sobre a microbiota intestinal, pois se aderem a diversos epitélios do sistema digestivo. As BALs são amplamente empregadas na indústria alimentícia, sendo utilizadas na fabricação de produtos lácteos e outros alimentos fermentados como queijos, iogurtes, carnes fermentadas e vinhos, contribuindo na produção de sabor e de textura característicos destes produtos, graças a ação de proteases e peptidases, agentes aromáticos ou exopolissacarídeos. Além disso, contribuem também para a conservação dos mesmos por inibirem o crescimento de bactérias deterioradoras e/ou patogênicas pela produção de substâncias inibidoras do crescimento, tais como bacteriocinas, ácidos orgânicos e peróxido de hidrogênio (SAAD et al., 2013).

Trois (2005) observou que diversas cepas láticas possuíam propriedades imunoestimulantes. Em estudo realizado por ANNUK et al. (2003) verificou-se que cepas heterofermentativas do gênero Lactobacillus como Lb. casei e Lb. paracasei mostraram maior inibição de bactérias Gram negativas patogênicas quando comparadas aos Lactobacillus homofermentativos, devido à alta redução de $\mathrm{pH}$ promovida no meio, causando maior efeito deletério sobre as bactérias patogênicas.

\subsubsection{Gênero Lactobacillus e importância na indústria de alimentos}

Os representantes do gênero Lactobacillus apresenta forma de bacilos ou de cocobacilos Gram positivos e estão presentes na microbiota intestinal de humanos e animais. São amplamente utilizados na indústria de limentos, em especial na tecnologia de produção de derivados lácteos, devido ao seu potencial probiótico (KONEMAN et al., 2005).

O gênero contém 160 espécies e 27 subespécies (EUZÉBY, 2009a) classificadas em três grandes grupos: os lactobacilos homofermentativos obrigatórios, os lactobacilos heterofermentativos facultativos e os lactobacilos heterofermentativos obrigatórios. Os lactobacilos homofermentativos obrigatórios são aqueles que fermentam hexoses em ácido lático; os heterofermentativos facultativos são os que fermentam hexoses somente, ou juntamente com acido acético, etanol e acido fórmico sob limitações de glicose e, os lactobacilos heterofermentativos obrigatórios fermentam hexoses em acido lático, acido acético, etanol e $\mathrm{CO}_{2}$ e pentoses em acido lático e acético (POT et al., 1994). 
Algumas espécies de Lactobacillus são utilizadas como probióticos, como por exemplo, Lb. rhamnosus, Lb. acidophilus, Lb. casei, Lb. reuteri e Lb. fermentum (REID, 1999). A produção de derivados lácteos contendo bactérias probióticas é um foco importante das indústrias e estes contêm geralmente, cepas probióticas específicas com concentrações apropriadas de células viáveis durante a vida de prateleira, sendo este processo um desafio tecnológico. Foi proposto que a dose mínima diária de culturas probióticas considerada terapêutica corresponde ao consumo de $100 \mathrm{~g}$ de produto contendo 6 a $7 \mathrm{log} \mathrm{UFC} / \mathrm{g}$ (MACEDO, 2005).

Shirota, em 1930, focou sua pesquisa na seleção de cepas de bactérias que pudessem sobreviver à passagem através do intestino e no uso dessas cepas para desenvolver leites fermentados para distribuição em sua clínica. Seu primeiro produto contendo Lb. casei Shirota (naquela época denominado Lb. acidophilus) foi a base para o estabelecimento da Yakult ${ }^{(S T U M E R ~ e t ~ a l ., ~ 2012) . ~}$

Os iogurtes ou produtos similares são os veículos mais populares para a incorporação de microrganismos probióticos (LÜCKE, 2000). Embora os produtos lácteos fermentados constituam uma fração substancial do mercado de probióticos, o número de produtos não lácteos é crescente, particularmente aqueles à base de soja (TYÖPPÖNEN et al., 2003). O consumo regular de alimentos contendo probióticos tem proporcionado evidências diretas ou indiretas sobre a redução do risco de câncer e de bexiga urinária e supressão de câncer cólon-retal. A importância do papel da microbiota intestinal na manutenção da saúde e prevenção de doenças é bastante reconhecida. Distúrbios desse equilíbrio podem gerar outras desordens e facilitar o estabelecimento de doenças (SACCARO, 2008).

Lb. sakei apresenta morfologia de bacilo isolado ou em pequenas cadeias, com dimensões variáveis entre 0,6-0,8/2-3 $\mu \mathrm{m}$, geralmente com extremidades arredondadas especialmente durante a fase estacionária de crescimento. Não se multiplica a $45^{\circ} \mathrm{C}$ mais pode crescer até $2^{\circ} \mathrm{C}$. A maioria das cepas produz ácido lático L (+) em caldo DE Man, Rogosa e Sharpe e ácido lático DL em suco de repolho prensado. Esse microrganismo é capaz de produzir uma bacteriocina denominada sakacin $P$ que inibe o crescimento de diversas bactérias patogênicas e deteriorantes presentes em produtos cárneos e pescado, sendo amplamente utilizado na fermentação desses produtos, apresentando importante potencial tecnológico. $L b$. sakei resiste às condições adversas dos processos de fermentação, tais como a concentração elevada do sal, a baixa atividade da água, a baixa temperatura e o $\mathrm{pH}$ (AXELSSON e AHRNÉ, 2000). 


\subsection{Substratos para desenvolvimento microbiano}

Segundo Franco e Landgraf (2008), a capacidade de sobrevivência ou de multiplicação de microrganismos depende de uma série de fatores. Entre esses fatores que podem propiciar, prevenir ou limitar o desenvolvimento dos microrganismos estão aqueles relacionados com as características dos substratos aos quais os microrganismos estão inseridos, denominados fatores intrínsecos, como a atividade de água, e os relacionados com o ambiente em que se encontra, denominados fatores extrínsecos, como a temperatura ambiente.

A concentração de substrato é um dos fatores que mais influenciam no crescimento de microrganismos, dependendo da susceptibilidade e capacidade de adaptação da estirpe ao meio (MADIGAN et al., 2004). Em um ambiente pobre em nutrientes ocorerrá um menor desenvolvimento microbiano, sendo os nichos preferenciais para o crescimento de microganismos locais que, proporcione uma maior troca de nutrientes entre o substrato e os microrganismos (OCHUA-HUESO et al., 2011). Os nutrientes que compõem o substrato são fatores que influenciam o número e a distribuição da população microbiana. Deste modo, o correto balanço dos nutrientes favorece o crescimento microbiano (VALADARES FILHO e SANTOS PINA, 2011).

As bactérias necessitam de alimento como fonte de energia, para elaborar o protoplasma e os seus materiais estruturais, diferindo muito entre si nas suas necessidades nutritivas. Os elementos mais importantes são: o carbono, o hidrogénio, o nitrogênio, o oxigénio e o fósforo. Necessitam também de quantidades menores de ferro, magnésio, potássio e cálcio e de outros elementos em quantidades mínimas. Como fontes de carbono e energia utilizam geralmente os hidratos de carbono e os aminoácidos, as necessidades de nitrogênio são satisfeitas com compostos orgânicos que contêm estes elementos, como por exemplo, as proteínas e certos aminoácidos (AZAM e MALFATTI, 2007).

Uma bactéria pode necessitar para a formação do seu material celular, de um ou mais compostos orgânicos que seja incapaz de sintetizar a partir de componentes mais simples. Tais nutrientes essenciais são necessários em pequenas quantidades e os nutrientes orgânicos deste tipo são conhecidos como fatores de crescimento. São de três tipos: aminoácidos que são necessários para a síntese proteica; purinas e pirimidinas que são necessárias para a síntese de ácidos nucleicos, como por exemplo, DNA e RNA; vitaminas que são necessárias à síntese de enzimas, como a timina e a riboflavina. Existem diversos grupos de bactérias em relação às suas fontes alimentares (SIQUEIRA, 2011). 
A fração de compostos quimicamente diferenciados, como proteínas, carboidrato, gorduras dentre outros varia de acordo com a origem do material. A respiração bacteriana possui, de forma geral, relação direta com a concentração de tais compostos. No entanto, deve-se observar que aspectos qualitativos, muitas vezes difíceis de definir, também são relevantes para o metabolismo bacteriano (PACE e PRAIRIE, 2005).

Del Giorgio e Cole, 1998 relatam que na comparação do uso de compostos diferenciados de diversas origens pelas bactérias, como matéria orgânica excretada pelo fitoplâncton, detritos de fitoplâncton, macroalgas, fezes animais e vegetação vascular, o consumo mais intenso foi observado sobre os compostos excretados pelo fitoplâncton, indicando a maior biodisponibilidade deste material. A razão estequiométrica (relação entre os reagente e produtos envolvidos em uma reação) dos compostos também é importante, uma vez que os mesmos atuam como fonte de nutrientes para os microrganismos. A concentração de fósforo e nitrogênio na água estimula o metabolismo microbiano, seja aumentando a produção secundária (FARJALLA et al., 2002a), seja intensificando a respiração bacteriana (HALL e COTNER, 2007).

Embora seja reconhecido que múltiplos fatores são capazes de limitar o metabolismo bacteriano, há uma tendência a estudar o efeito de apenas um fator limitante por vez, dada a dificuldade de lidar com duas ou mais variáveis simultaneamente em comunidades naturais (POMEROY e WIEBE, 2001). Hall e Cotner (2007) mostraram o efeito interativo da temperatura com concentrações de nutrientes inorgânicos sobre a respiração bacteriana, embora não tenham avaliado a influência de nitrogênio e fósforo separadamente. A interação entre concentrações de substrato e temperatura também foi evidenciada (POMEROY e WIEBE, 2001), embora não tenha sido feita uma análise quantitativa da disponibilidade de substrato.

Há uma grande lacuna na compreensão de como diversos fatores atuam em conjunto na regulação do metabolismo bacteriano, e é importante que os efeitos sejam analisados de forma independente e interativa, quantificando a disponibilidade de componentes orgânicos diferenciados e nutrientes. Em um cenário de busca de melhoria da qualidade de produtos cada vez mais abrangentes, é fundamental compreender o efeito que alterações e composição do substrato podem causar sobre o metabolismo bacteriano (SIQUEIRA, 2011).

O estudo da influência das condições como temperatura, $\mathrm{pH}$, tipos de cultura e substratos, permite a obtenção de informações sobre a fisiologia de cepas bacterianas 
sendo portanto interessante conhecer o efeito dessas condições sobre os microrganismos (OLIVEIRA e DAMIN, 2003).

\subsubsection{Principais componentes do leite}

A preocupação com o consumo de alimentos considerados saudáveis e seguros deve-se principalmente pela ampla divulgação de surtos de DTAs (DÜRR et al., 2011). Dentre os produtos de origem animal, o leite tem elevado valor nutricional. Constitui uma das principais fontes de proteínas na alimentação de animais jovens e de humanos de todas as idades (RIBEIRO et al., 2006). Assim, deve apresentar condições sanitárias adequadas, ser isento de qualquer forma de contaminação ou substância estranha (GRADELHA, 2008).

O leite é uma substância que tem como constituintes a água (87\%), além de componentes orgânicos como proteínas $(3,2 \%)$, gordura $(3,9 \%)$, lactose $(4,5-4,8 \%)$, vitaminas e minerais, o que o torna uma fonte de nutrientes para o desenvolvimento de diversos microrganismos patogênicos como E. coli, S. aureus, L. monocytogenes, Salmonella spp, fungos e leveduras além dos Lactobacillus. Por isso, as etapas de obtenção, beneficiamente e produção de derivados devem ser conduzidas com rigor, quanto às boas práticas e processos de limpeza, para evitar contaminações que além de alterar os produtos, podem representar riscos à saúde (RIBEIRO et al., 2006; RIBAS, 2008; OLIVEIRA et al., 2013).

O conhecimento da composição do leite é essencial para um efetivo controle de qualidade, pois define diversas propriedades organolépticas e industriais. Além disso, também é importante para a fabricação de produtos lácteos e seus derivados. Os parâmetros de qualidade são utilizados para detecção de falhas nas práticas de manejo e servem como referência na valorização da matéria-prima (DURR, 2004). A composição química deve ser sempre analisada nos laticínios e nas indústrias em razão dos padrões exigidos pelo Ministério da Agricultura Pecuária e Abastecimento (BRASIL, 2011).

O leite bovino apresenta em média $4 \%$ de gordura, variando de 2,5 a 5,5\%. Estruturalmente, é uma mistura complexa de componentes e os lipídios ficam em estado de emulsão. A gordura está presente na forma de glóbulos, constituídos por um núcleo, composto principalmente de triglicerídios, protegido por uma membrana lipoproteica, e a maioria dos ácidos graxos encontrados, saturados e insaturados e contém de dois a 20 átomos de carbono em suas cadeias. Outros lipídios presentes incluem fosfolipídios, colesterol, ácidos graxos livres, mono e diglicerídios. A gordura do leite contribui para as características de textura, sabor e estabilidade de produtos derivados de leite, além de ser fonte de energia, ácidos 
graxos essenciais e vitaminas liposolúveis (BAUMAN e LOCK, 2006; ARGOV et al., 2008; GRADELHA, 2008).

As proteínas do leite são facilmente digeridas e tem alto valor biológico. São constituídas de aminoácidos essenciais em quantidades e proporções adequadas. A caseína é a principal proteína do leite e a que se apresenta em maior quantidade constituindo $80 \%$ do total de proteínas e apresentando concentração média de 24 a 28 mg/mL (BONDAN, 2015). A síntese da caseína ocorre nas células epiteliais da glândula mamária e é secretada na forma de micelas, sendo constituída por quatro variantes genéticas: $\alpha$-S1, $\alpha$-S2, $\beta$ e k-caseína. A caseína é normalmente estável a altas temperaturas e não é afetada pela pasteurização, contudo quando há acidificação do leite ocorre desestruturação da micela e formação de coágulo. Também ocorre a proteólise da $\beta$-caseína que gera a $\gamma$-caseína (1 a $2 \mathrm{mg} / \mathrm{mL}$ ) e outros peptídeos menores (SANTOS e FONSECA, 2007). Segundo O'connell e Foz (2000) o tamanho da micela é determinado pelo conteúdo de k-caseína. Quanto maior for à proporção de k-caseína da micela, menor seu tamanho. As moléculas de caseína contêm em média 96\% de proteínas, 2,8\% de cálcio; $2,3 \%$ de fosfato orgânico; $2,9 \%$ de fosfato inorgânico; $0,4 \%$ de citrato, além de baixos níveis de Mg, Na e K (ABREU, 2008).

No leite também são encontradas as proteínas solúveis e proteínas do soro, que são proteínas globulares como as $\beta$-lactoalbumina, $\alpha$-lactoalbumina, proteoses-peptonas, imunoglobulinas, transferrina, lactoferrina e enzimas. As soroproteínas diferem da caseína por sua estrutura globular. As caseínas possuem estrutura micelar (quaternária), as proteínas do soro caracterizam-se por dispersão molecular e estrutura terciária. Além disso, tem alto valor nutricional, atribuído pelo teor de aminoácidos sulfurados, relativamente termolábeis, pois se desnaturam a uma temperatura de $65^{\circ} \mathrm{C}$. Não são fosforiladas, o que diminui sua estabilidade térmica e solubilidade em íons de calcio (PEREIRA et al, 2002; ABREU, 2008).

A lactose (beta-galactosil-1-4-glicose) é um dissacarídeo (beta-galactosídeo) composto de glicose e de galactose. A única fonte natural deste carboidrato é o leite dos mamíferos. Ela constitui a primeira fonte de hidrato de carbono para os mamíferos. A lactose é sintetizada nas células epiteliais das glândulas mamárias mediante uma reação que depende de duas proteínas, a alfa-lactalbumina e a enzima N-acetilgalactosil-transferase. Sua concentração no leite varia segundo a espécie, sendo, por exemplo, de cerca de $7 \%$ no leite humano e de cerca de $5 \%$ no leite de vaca (SILVA et al., 2010). O conteúdo de lactose do leite nas várias espécies é proporcional à atividade da alfa-lactoalbumina tendo sido verificado que os animais que não possuem essa proteína também não produzem lactose, como os leões marinhos e as focas do Oceano Pacífico. Do mesmo modo, a concentração de 
lactose varia de acordo com o produto lácteo, e a fervura e a pasteurização não altera o conteúdo de lactose do leite (PRATA, 2001; SILVA et al., 2010).

O leite contém sais minerais como cloretos, fosfatos e citratos, fundamentais para a estabilidade térmica e há, ainda, a presença em quantidades significativas $(0,6$ a 0,8\% do peso do leite) de $\mathrm{K}, \mathrm{Ca}, \mathrm{Na}, \mathrm{Mg}, \mathrm{Cl}$ e $\mathrm{S}$ (PRATA, 2001). Há alta disponibilidade de cálcio e fósforo no leite, em parte porque se encontram associados à caseína. O conteúdo de ferro é baixo (BRITO et al., 2004). Também é fonte de vitaminas, algumas se associam com a gordura (A, D, E e K), enquanto outras se associam com a parte aquosa. Dentre as últimas, estão as do complexo B e a vitamina C. Mais de dez vitaminas diferentes do complexo B são encontradas no leite. Entretanto, com exceção da vitamina B2, são encontradas em quantidades pequenas (BRITO et al., 2004).

\subsection{Biofilmes na indústria de alimentos e importância da higienização}

Uma das grandes preocupações das indústrias alimentícias é a garantia da qualidade microbiológica de seus produtos, visando à redução de perdas decorrentes da deteriorização e à diminuição de riscos a saúde do consumidor. Neste contexto a questão da formação de biofilmes bacteriano em plantas de processamento de alimentos tem sido amplamente estudada nos últimos anos (DAVIDSON e BRANEM, 2005).

Sua ocorrência tem relação direta com a qualidade da matéria-prima, ritmo de produção, utilização de equipamentos complexos e automação de plantas, sendo estas as principais causas da contaminação dos produtos. A formação de biofilmes causas prejuízos como corrosão de superfícies de equipamentos, aumento da resistência a sanitizantes e na contaminação dos produtos por bactérias patogênicas e deteriorantes (ANDRADE et al., 2008, MEIRA et al., 2012).

A manutenção do biofilme esta intimamente relacionada com o mecanismo denominado quórum-sensing, que consiste basicamente na produção e liberação de moléculas sinalizadoras e auto-indutoras, cuja concentração aumenta em função da densidade populacional bacteriana (WATERS, 2005).

Os principais microrganismos que formam biofilmes são Escherichia coli, Staphylococcus spp, Pseudomonas aeruginosa, Listeria monocytogenes (KAPLAN, 2004).

A matriz de um biofilme corresponde em geral $97 \%$ de água que junto com os solutos dissolvidos determinam as características de viscosidade da matriz e condições 
de difusão dos solutos em seu interior, como nutrientes e metabólitos. A adesão dos microrganismos a superfície é influenciada pela natureza do substrato, temperatura, presença de flagelos e o estágio de desenvolvimento bacteriano (HOLLEY, 2013).

A elevada quantidade de resíduos resultantes do processamento de alimentos favorece a formação de biofilmes em equipamentos, fornecendo proteção aos microrganismos (CHMIELEWSKI e FRANK, 2003). Na indústria de laticínios, resíduos de leite, especialmente proteínas e sais minerais, constituem a matriz de biofilmes (BREMER et al., 2006).

A compreensão da influência de todas as variáveis envolvidas na formação de biofilmes, como composição da superfície, tipos de resíduos presentes (carboidratos, gorduras, proteínas e sais minerais) e espécies bacterianas auxilia no entendimento do processo de estabelecimento do biofilme e no seu controle dentro da indústria (SIMÔES e VIEIRA, 2010).

Diversidade metabólica e a capacidade de adaptação a estresses ambientais são características fundamentais dos microrganismos (LÓPEZ et al., 2010). A adesão bacteriana, seja em uma superfície abiótica ou biótica, é o primeiro estágio na formação de biofilmes e é considerado um processo bastante complexo. Como regra geral, a adesão primária (ou adesão reversível) entre bactérias e superfícies abióticas ocorre mediada por interações físicoquímicas não específicas, enquanto que a adesão a superfícies bióticas é acompanhada por interações moleculares mediadas por ligações específicas do tipo receptor-ligante, através de lectinas ou adesinas (DUNNE, 2002).

As condições higiênico-sanitárias em uma indústria de alimentos são fundamentais para a qualidade do produto final. A limpeza e a sanitização evitam a contaminação e aumentam a vida de prateleira do produto oferecido à população, evitando dessa forma, não só prejuízos financeiros para indústria e consumidores, como também problemas relacionados à saúde pública. Os nutrientes dos alimentos, como as proteínas, gorduras, carboidratos e sais minerais, deixam resíduos nos equipamentos de processamento da indústria, os quais, se não forem bem removidos, poderão acarretar em problemas de qualidade (JACQUES et al., 2015).

A higienização na indústria de alimentos se insere junto as Boas Práticas de Fabricação (BPF) e à Análise de Perigos e Pontos Críticos de Controle (APPCC), e tem como objetivo principal a obtenção de produtos seguros para a população humana (ANDRADE, 2008). A higienização é composta pelas etapas de limpeza e sanitização das superfícies, ambientes de processamento, equipamentos, utensílios, manipuladores e ar do ambiente de 
processamento. A limpeza tem como objetivo fundamental remover os resíduos orgânicos e minerais aderidos às superfícies, constituídos principalmente por carboidratos, proteínas, gorduras e sais minerais. Já a sanitização engloba a eliminação dos microrganismos patogênicos e a redução do número dos deteriorantes a níveis considerados seguros para a população humana (BELTRAME et al., 2012).

As etapas do processo de higienização levam em consideração as características de solubilidade dos resíduos de alimentos em água ou em detergentes alcalinos e ácidos. Resíduos de carboidratos e de sais minerais monovalentes podem ser removidos com certa facilidade pela água associada à ação mecânica, desde que estes resíduos não tenham sofrido a ação do calor. Já os resíduos de gordura são removidos com o uso de agentes alcalinos ou tensoativos e para a remoção de sais minerais divalentes como o cálcio e o magnésio são utilizados os agentes químicos ácidos. Para remoção de resíduos proteicos utilizam-se os agentes alcalinos (Quadro 2) (ANDRADE, 2008).

Quadro 2. Solubilidade em água, facilidade de remoção e o efeito do calor dos principais resíduos em equipamentos de processamento em laticínios

\begin{tabular}{|c|c|c|c|}
\hline Resíduo & Solubilidade & $\begin{array}{c}\text { Facilidade de } \\
\text { Remoção }\end{array}$ & Efeito do Calor \\
\hline Carboidrato & $\begin{array}{c}\text { Geralmente } \\
\text { solúveis em água }\end{array}$ & Fácil & Caramelização \\
\hline Gordura & $\begin{array}{l}\text { Insolúveis em água, } \\
\text { solúveis em } \\
\text { alcalinos, solúveis } \\
\text { por tensoativos }\end{array}$ & Difícil & Polimerização \\
\hline Proteínas & $\begin{array}{c}\text { Solúveis em } \\
\text { alcalinos, Solúveis } \\
\text { em ácidos }\end{array}$ & Dificil & Desnaturação \\
\hline $\begin{array}{l}\text { Sais minerais } \\
\text { monovalentes } \\
\qquad\left(\mathrm{Na}^{+}, \mathrm{K}^{+}\right)\end{array}$ & Solúveis em água & Fácil & Incrustações \\
\hline $\begin{array}{c}\text { Sais minerais } \\
\text { divalentes }\left(\mathrm{Ca}^{++} \mathrm{e}\right. \\
\left.\mathrm{Mg}^{++}\right)\end{array}$ & Solúveis em ácidos & Difícil & Incrustações \\
\hline
\end{tabular}

Fonte: ANDRADE, 2008. 
A importância da pesquisa e do conhecimento associado com as etapas da limpeza e, o uso de diferentes produtos para higienização e sanitização na indústria alimentícia está em oferecer aos consumidores produtos com qualidade, respeitando as características sanitárias do alimento. Entre os produtos utilizados na limpeza estão os detergentes alcalinos, ácidos e os tensoativos. Para a sanitização, há meios físicos e químicos (ANDRADE, 2008).

A eficiência dos sanitizantes para tratamento de superfície de alimentos pode ser limitada ou imprevisível quando grande quantidade de matéria orgânica está presente na água de lavagem (RUÍZ-CRUZ et al., 2007; RAHMAN et al., 2011). Dentre os sanitizantes empregados na indústria de alimentos, principalmente em produtos frescos, a maioria é a base de cloro e compostos clorados (NASCIMENTO e SILVA, 2010; CHEN e ZHU, 2011; CHEN et al., 2013). A facilidade do uso, o baixo custo, atividade antimicrobiana e a completa dissolução em água, fazem com que os agentes clorados sejam frequentemente utilizados como sanitizantes na indústria alimentícia (SELMA et al., 2008; NASCIMENTO e SILVA, 2010; SHEN et al., 2012).

A ação oxidante e sanitizante dos derivados clorados é controlada pelo ácido hipocloroso $(\mathrm{HClO})$, produto resultante da hidrólise da substância clorada, que é a forma de cloro livre disponível com amplo espectro de ação contra diferentes microrganismos (PARISH et al., 2003). O ácido hipocloroso ( $\mathrm{HClO})$ libera oxigênio causado oxidação. O oxigênio combina com componentes do protoplasma celular. Além disso, o próprio cloro pode se juntar a proteínas de membrana celular e interferir no metabolismo microbiano, principalmente na inibição de enzimas da via glicolítica (VEIGA, 2003).

O cloro é uma substância corrosiva, que pode provocar irritações na pele e no trato respiratório (ALVARO et al., 2009). Além disso, outra preocupação com o uso do cloro está associada à possibilidade de hipercloração da água residual que, associada ao alto conteúdo de carbono orgânico, pode resultar em concentrações elevadas de trihalometanos, e outros subprodutos da desinfecção (RUÍZ-CRUZ et al., 2007; RICO et al., 2007; RYANBARRY et al., 2008; SELMA et al., 2008; RAHMAN et al., 2011).

A Agência Internacional para Pesquisa do Câncer classifica esses subprodutos do processo de cloração como cancerígenos e a Agência de Proteção ao Meio Ambiente (Enviromental Protection Agency-EPA) estabeleceram, em 1998, o limite de concentração máxima de $80 \mu \mathrm{g} \cdot \mathrm{L}^{-1}$ para trihalometanos totais. Muitos países europeus, tais como a Alemanha, têm restringido este limite a $10 \mu \mathrm{g} \cdot \mathrm{L}^{-1}$ (MACÊDO et al., 2001; PAVÓN et al., 2008). No Brasil, a Portaria do Ministério da Saúde de n 2914 de 14 de dezembro de 2011, que estabelece normas para a qualidade da água para consumo humano e seu padrão de 
potabilidade, indica que a concentração máxima permitida de trihalometanos totais em água é de $0,1 \mathrm{mg} / \mathrm{L}^{-1}$ (BRASIL, 2011).

Neste contexto, os compostos clorados têm sido foco de preocupação ambiental e alguns grupos ambientalistas têm sugerido a extinção do uso desse produto em todo o mundo (RICO et al., 2007; NASCIMENTO et al., 2008; ÖLMEZ e KRETZSCHMAR, 2009; TORNUK et al., 2011; RAHMAN et al., 2011).

A sanitização é uma etapa essencial para atribuir maior segurança e extensão da vida de prateleira de produtos e, as crescentes restrições quanto ao uso do cloro, há a necessidade da busca por tecnologias alternativas (RUÍZ-CRUZ et al., 2007; ALLENDE et al., 2008b; RICO et al., 2008; VANDEKINDEREN et al., 2008; ALVARO et al., 2009; GRAÇA et al., 2011; CHEN e ZHU, 2011). Concomitantemente, há também a busca por técnicas de desinfecção capazes de reduzir com maior eficiência, a contaminação microbiana na água de lavagem e nos alimentos (ONGENG et al., 2006; SÃO JOSÉ e VANETTI, 2012).

Considerando a importância da etapa de sanitização, o estudo de métodos e/ou agentes alternativos devem receber atenção especial. Dentre as alternativas propostas destacam-se uso de luz ultravioleta, irradiação, ozônio (MARTíN-DIANA et al., 2006; SELMA et al., 2008), ácido peracético (ALVARO et al., 2009), água eletrolisada (ABADIA et al., 2008; RICO et al., 2008; ÖLMEZ e KRETZSCHMAR, 2009; GRAÇA et al., 2011), ácidos orgânicos (AKBAS e ÖLMEZ, 2007a e b) , o uso do ultrassom (GUERRERO et al., 2001; SEYMOUR et al., 2002; MASON 2005, CAO et al., 2010; SÃO JOSÉ e VANETTI, 2012) e soluções com prata (AJLOUNI, 2003; GOPAL et al., 2010).

O objetivo principal destas alternativas para sanitização é assegurar a conservação de alimentos, mantendo seu valor nutritivo e as características sensoriais (textura, cor e sabor) inalterados, com baixo consumo de energia, a custo competitivo, respeito pelo ambiente e alto grau de segurança (KODA et al., 2009; GÓMEZ-LÓPEZ et al., 2010; CHEMAT et al., 2011).

Dentre os diferentes métodos alternativos de sanitização estudados, o ozônio é uma tecnologia que vem ganhando espaço na indústria de alimentos. Esta alternativa pode ser útilizada com diferentes objetivos, dentre eles, a remoção de partículas aderidas a superfícies e a inativação de microrganismos. Essa tecnologia associada à sanitizantes permite maior redução da contaminação microbiana de alimentos (CHEMAT et al., 2011; CAVALCANTE, 2013).

O Quadro 3 compara as características dos processos de desinfecção com cloro e com ozônio, em relação à segurança, a remoção de microrganismos, ao residual tóxico, a 
formação de subprodutos, aos custos operacionais e de investimento. Segundo Lazarova et al. (1999), investimentos no processo de desinfecção por ozônio podem ser vantajosos em função da remoção de um numero maior de microrganismos, especialmente vírus e cistos de protozoários e da geração de subprodutos menos tóxicos.

Quadro 3. Comparação das características dos processos de cloração e de ozonização.

\begin{tabular}{|l|c|c|}
\hline \multicolumn{1}{|c|}{ Características } & Cloração & Ozonização \\
\hline Segurança & + & ++ \\
\hline Remoção de batérias & ++ & ++ \\
\hline Remoção de vírus & + & ++ \\
\hline Remoção de protozoários $^{1}$ & - & ++ \\
\hline Residual tóxico & +++ & + \\
\hline Subprodutos & +++ & ++ \\
\hline Custos operacionais & + & +++ \\
\hline Custos de investimento & ++ & + \\
\hline
\end{tabular}

Legenda: -, nenhum; +, baixo; ++, médio;+++, alto.

${ }^{1}$ Análise in vitro de Criptosporidium spp

Fonte: Lazarova et al, 1999.

\subsection{Ozônio}

O ozônio é um gás composto por três átomos de oxigênio. Dois átomos constituem a molécula do oxigênio, o terceiro átomo, com característica de alta instabilidade pode facilmente se desligar do ozônio para se ligar a moléculas de outras substâncias orgânicas provocando alterações na sua composição química (KECHINSKI, 2007).

O significado da palavra ozônio vem do grego ozein, que significa mal cheiro. Isto reflete uma de suas características, pois o ozônio apresenta odor forte quando em alta concentração. O gás é considerado um eficiente sanitizante, sendo este utilizado no tratamento de produtos alimentícios em países da Europa e Ásia. Existem relatos que desde o início do século 20 o ozônio é aplicado como agente sanitizante na indústria alimentícia, e auxilia na preservação dos alimentos e ingredientes (KIM et al., 1999).

Há também registros do uso como coadjuvante de processamento de alimentos e bebidas, sendo muito usado na purificação e envelhecimento artificial de bebidas alcoólicas, como vinhos e destilados, e na produção de sidra, como agente de desinfecção e controle do odor. Na Europa é usado de forma segura e eficiente no tratamento de água de 
abastecimento da rede pública e no processamento de alimentos e no tratamento de água potável do município de San Petesburg em 1910 (NASCIMENTO et al., 2005).

Nos EUA, sua utilização foi feita com o intuito de remover íons de ferro, manganês, cor, sabores e odores de produtos alimentícios e água. Desde 1933, diversos estudos foram realizados com uma grande variedade de produtos como maçã, batata, tomate, morango, brócolis, pêra, laranjas, pêssegos, uvas, milho e soja. No ano de 1940, foi instalada a primeira estação de tratamento de água com ozonização contínua. Em 1982, a Food and Drugs Administration (FDA) declarou água engarrafada ozonizada como um produto seguro ao consumo, integrando a lista de produtos GRAS (Generally Recognized as Safe). Em plantas de tratamento de água potável foi reconhecido e declarado como sanitizante seguro para uso direto em alimentos (United States Departament of Agriculture, 2001).

O ozônio é usado na Europa como sanitizante e nos EUA é usado como sanitizante em alimentos sem restrição alguma. Estudos indicam que o gás pode ser utilizado como antimicrobiano seguro e eficiente em muitas aplicações, sendo necessárias baixas concentrações e tempo reduzido para obtenção de um resultado eficiente na redução de microrganismos (KIM et al., 1999).

\subsubsection{Propriedades do ozônio}

O ozônio é produzido na estratosfera (25 a $30 \mathrm{~km}$ da superfície terrestre) através da radiação ultra-violora $(<83 \mathrm{~nm})$, que realiza a quebra das moléculas de oxigênio em dois átomos altamente ativos. Por meio de uma reação endotérmica, cada um destes átomos se liga ao oxigênio intacto $\left(\mathrm{O}_{2}\right)$ para então formar a molécula de ozônio $\left(\mathrm{O}_{3}\right)$. Também pode ser produzido durante uma descarga elétrica, o que catalisa a produção de ozônio a partir do oxigênio atmosférico (PIRANI, 2011). Como demonstrado na figura 1, os três átomos de oxigênio da molécula de ozônio são dispostos em ângulo obtuso, em que um átomo de oxigênio central está ligado a dois átomos de oxigênio equidistantes, o ângulo incluído é de aproximadamente $116^{\circ} 49^{\prime}$ e a ligação tem um comprimento de $1.278 \AA$ (GUZEL-SEYDIM et al., 2004). 


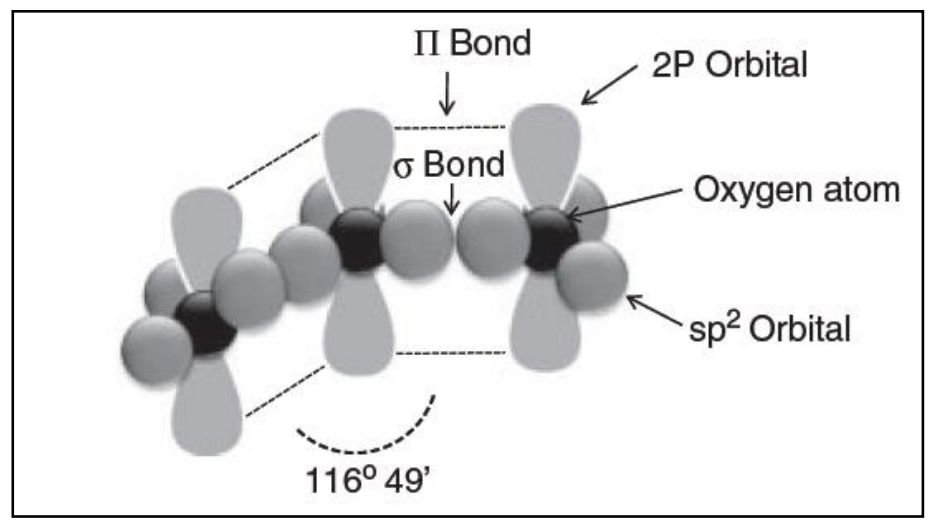

Figura 1. Estrutura molecular do ozônio

Fonte: GREENE et al., 2012.

É incolor, parcialmente solúvel em água, instável, evapora em temperatura de $112^{\circ} \mathrm{C}$, à pressão atmosférica. $\mathrm{O}$ quadro 4 apresenta outras propriedades do ozônio. Mesmo em baixas concentrações seu cheiro é facilmente perceptível (LAPOLLI et al., 2003). A $0^{\circ} \mathrm{C}$, a solubilidade do ozônio é $0.640 \mathrm{~L}$ de ozônio/L de água, enquanto a $60^{\circ} \mathrm{C}$, é insolúvel (HILL e RICE, 1982). Pehkonen (2001) destaca que alguns cenários sugerem que o mecanismo de decomposição do ozônio na água resulta formação de $\mathrm{O}_{2}$ e $\mathrm{H}_{2} \mathrm{O}$ e outros intermediários reativos como radicais hidroxil, íons de hidróxido, sendo que em $\mathrm{pH}$ acima de 7.5, ocorre produção de radicais hidroxila. De acordo com Silva et al. (2011), a taxa de desinfecção pelo ozônio é relativamente independente da temperatura.

Quadro 4. Principais características físico-químicas do gás ozônio puro.

\begin{tabular}{|cl|}
\hline \multicolumn{2}{|c|}{ Propriedades físico-químicas } \\
\hline Ponto de ebulição & $-111,9 \pm 0,3^{\circ} \mathrm{C}$ \\
\hline Ponto de fusão & $-192,5 \pm 0,4^{\circ} \mathrm{C}$ \\
\hline Temperatura crítica & $-12,1^{\circ} \mathrm{C}$ \\
\hline Pressão crítica & $54,6 \mathrm{~atm}$ \\
\hline Calor de formação & $144,7 \mathrm{~kJ} / \mathrm{mol}$ \\
\hline Peso molecular & $47,9982 \mathrm{~g} / \mathrm{mol}$ \\
\hline
\end{tabular}

Fonte: adaptado de SILVA et al., 2011; PIRANI, 2011; GUZEL-SEYDIM et al., 2004.

Quando comparado a outros agentes oxidantes, o ozônio se destaca pelo elevado potencial de oxidação, que é de $2,07 \mathrm{mV}$, sendo eficiente na eliminação de microrganismos através de oxidação de suas membranas. Seu potencial oxidativo perde apenas para o flúor que é de 3,06 mV (SILVA et al., 2011; LAPOLLI et al., 2011), Abaixo é demonstrado o potencial oxidativo de diferentes agentes oxidantes (Quadro 5). 
Quadro 5. Agentes oxidantes e seus respectivos potenciais de oxidação.

\begin{tabular}{|c|c|}
\hline Agente oxidante & Potencial de oxidação (mV) \\
\hline Flúor & 3,06 \\
\hline Ozônio & 2,07 \\
\hline Peróxido de hidrogênio & 1,78 \\
\hline Permanganato & 1,67 \\
\hline Dióxido de cloro & 1,50 \\
\hline Hipoclorito & 1,49 \\
\hline Cloro & 1,36 \\
\hline
\end{tabular}

Fonte: adaptado de PIRANI, 2011.

\subsubsection{Geração de ozônio}

Para que ocorra a geração do gás ozônio, é necessária a separação de uma molécula diatômica de oxigênio. A partir da separação desta, o oxigênio estará livre para reagir com uma molécula diatômica formando assim a molécula triatômica. Porém, para que tal reação ocorra e haja quebra da ligação O-O, uma grande quantidade de energia é essencial (O’DONNELL, 2012). Logo, a reação é altamente endotérmica $(\Delta \mathrm{G}=+161,3 \mathrm{~kJ} / \mathrm{mol})$ e é descrita da seguinte forma: $3 \mathrm{O}_{2} \leftrightarrow 2 \mathrm{O}_{3} \Delta \mathrm{H}=+284,5 \mathrm{~kJ} / \mathrm{mol}$ (SILVA et al., 2011).

Os principais métodos para ocorrer tal reação são o uso de radiação ultravioleta (188 nm) - método fotoquímico - e a descarga elétrica (processo corona) (figura 2), que, por ser mais eficiente, é utilizada para a geração de ozônio em níveis comerciais.

No processo corona, dois eletrodos submetidos à elevada diferença de potencial de aproximadamente $100 \mathrm{~V}$ são separados por uma estreita lacuna, por onde passa ar ou oxigênio puro (SILVA et al., 2011; O’DONNELL, 2012). Quando os elétrons possuem energia suficiente para dissociar a molécula de oxigênio, começam a ocorrer colisões, que causam a dissociação do oxigênio e a consequente formação do ozônio (USEPA, 1999). 


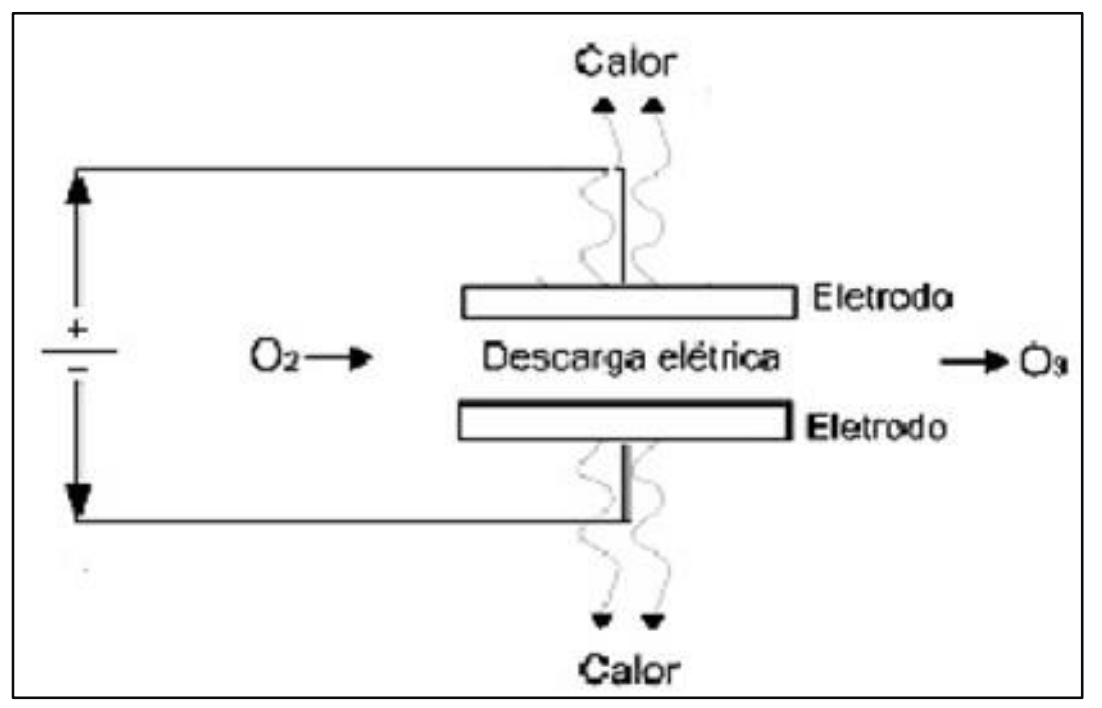

Figura 2. Geração do ozônio através do processo corona Fonte: GUZEL-SEYDIM et al., 2004

Segundo Lapolli et al. (2003), há dois sistemas de geração de ozônio: um a partir do ar e outro a partir do oxigênio puro. Para utilização do ar, é necessário seu prétratamento (filtração, compressão, resfriamento e desumidificação). A produção a partir de oxigênio puro, que tem um rendimento maior, exige a alimentação do gerador com um tanque de oxigênio líquido precedido de um evaporador, o que é uma desvantagem em relação ao custo.

\subsubsection{Segurança}

A toxicidade do ozônio varia com a sua concentração e a duração da exposição. Tem alta ação oxidante e pode causar doenças graves e até a morte aos animais, plantas e organismos vivos se inalado em quantidade elevada. Os sinais de toxicidade são acentuados, irritação no nariz e garganta que podem surgir imediatamente após contato com o gás à concentração de 0,1 ppm. Perda de visão pode surgir após três a seis horas de exposição em concentrações de 0,1 a 0,5 ppm (PIRANI, 2011) além de cefaleia, angina no peito, tosse e garganta seca. Maiores níveis de ozônio (5-10 ppm) podem causar aumento do pulso e edema pulmonar.

Ozônio em níveis de 50 ppm ou mais é potencialmente fatal. Os níveis de exposição ao ozônio como recomendado pelo Departamento de Segurança e Saúde Ocupacional (OSHA) dos EUA são mostrados no quadro 6. 
Quadro 6. Níveis apropriados de aplicação do ozônio.

\begin{tabular}{|c|c|}
\hline Exposição & Nível de ozônio (ppm) \\
\hline Odor detectável & $0,01-0,05$ \\
\hline Limite de 8 horas (OHSA) & 0,1 \\
\hline Limite de 15 minutos (OHSA) & 0,3 \\
\hline Letal em poucos minutos & $>1700$ \\
\hline
\end{tabular}

Fonte: adaptado de PIRANI, 2011.

\subsubsection{Ação antimicrobiana do ozônio}

O ozônio é um poderoso agente oxidante, eficaz na inativação de bactérias, bolores, leveduras, vírus, protozoários, inclusive formas esporuladas e cistos de protozoários, que são mais resistentes. A molécula de ozônio atua como um dipolo com propriedades eletrolíticas e nucleofílicas, reagindo, em soluções aquosas, com componentes orgânicos e inorgânicos (SOUZA, 2006; da MATTA JÚNIOR, 2015). O ozônio inativa diversas bactérias, incluindo Gram negativas e Gram positivas, células vegetativas e formas esporuladas, além de componentes do envoltório celular, esporos fúngicos ou capsídeos virais, em concentrações relativamente baixas e em reduzido tempo de contato (KIM et al., 1999; KHADRE et al., 2001; PRESTES, 2007). A redução ou a inativação da população microbiana devido à ozonização depende da concentração de ozônio, do tempo de aplicação e do microrganismo envolvido (KIM e YOUSEF, 2000).

Com o aumento da temperatura, o ozônio se torna menos solúvel e menos estável em água, entretanto as taxas de desinfecção e de oxidação química permanecem relativamente estáveis, a eficiência da desinfecção parece ter pouca influência da temperatura até $30^{\circ} \mathrm{C}$ (USEPA; 1999; DI BERNARDO e DANTAS, 2005). Estudos mostram que um aumento na temperatura de 0 a $30^{\circ} \mathrm{C}$ pode reduzir a solubilidade do ozônio e aumentar significativamente sua taxa de decomposição, porém não há nenhum efeito na taxa de desinfecção de bactérias (LANGLAIS et al., 1991; DI BERNARDO e DANTAS, 2005).

Sabe-se que a taxa de destruição de microrganismos aumenta com o aumento da temperatura (VIDAL, 2003; LAPOLLI et al., 2003; LANGLAIS et al., 1991). De acordo com a teoria de van’t Hoff-Arrhenius, a temperatura determina, em parte, a taxa à qual o desinfetante se difunde através da superfície do microrganismo e a sua taxa de reação com o substrato (LANGLAIS et al., 1991). Quando ocorre um aumento de temperatura, o ozônio 
torna-se menos solúvel e menos estável em água, porém a taxa de reação com o substrato orgânico dos microrganismos aumenta (LAPOLLI et al., 2003; LANGLAIS et al., 1991).

O ozônio atua inicialmente na membrana celular, sendo a superfície da célula microbiana o primeiro alvo a ser atingido. Sua ação antimicrobiana é decorrente da oxidação de glicolipídeos, glicoproteínas e aminoácidos da parede celular, alterando a permeabilidade e causando sua rápida lise. O ozônio ataca também grupos sulfidrila de enzimas, ocasionando o colapso da atividade enzimática celular. Além disso, sua ação sobre o material nuclear dos microrganismos altera as bases púricas e pirimídicas dos ácidos nucleicos, como ocorre com alguns vírus, onde o ozônio destrói seu RNA além de alterar as cadeias polipeptídicas do capsídeo proteico (SILVEIRA, 2004; HUNT e MARIÑAS, 1999).

$\mathrm{O}$ pH não apresenta influência direta na desinfecção de bactérias, vírus e protozoários, as alterações na eficiência do processo de desinfecção estão relacionadas com mudanças na taxa de decomposição do ozônio em função do pH. Sabe-se que em valores de pH mais elevados ocorre a formação de radicais livres de hidroxila, com elevado poder de oxidação, enquanto em valores menores que o pH neutro, a eficiência da desinfecção tem sido creditada ao ozônio molecular (LANGLAIS et al., 1991; DI BERNARDO e DANTAS, 2005).

Com o aumento da temperatura, o ozônio se torna menos solúvel e menos estável em água, entretanto as taxas de desinfecção e de oxidação química permanecem relativamente estáveis, a eficiência da desinfecção parece ter pouca influência da temperatura até $30^{\circ} \mathrm{C}$ (DI BERNARDO e DANTAS, 2005; USEPA; 1999). Estudos mostram que um aumento na temperatura de 0 a $30^{\circ} \mathrm{C}$ pode reduzir a solubilidade do ozônio e aumentar significativamente sua taxa de decomposição, porém não há nenhum efeito na taxa de desinfecção de bactérias (LANGLAIS et al., 1991; DI BERNARDO e DANTAS, 2005).

Sabe-se que a taxa de destruição de microrganismos aumenta com o aumento da temperatura (LANGLAIS et al., 1991; VIDAL, 2003; LAPOLLI et al., 2003). De acordo com a teoria de van't Hoff-Arrhenius, a temperatura determina, em parte, a taxa à qual o desinfetante se difunde através da superfície do microrganismo e a sua taxa de reação com o substrato (LANGLAIS et al., 1991). Quando ocorre um aumento de temperatura, o ozônio torna-se menos solúvel e menos estável em água, porém a taxa de reação com o substrato orgânico dos microrganismos aumenta (LANGLAIS et al., 1991; LAPOLLI et al., 2003).

A ozonização é um tratamento altamente eficaz contra microrganismos patogênicos ou deterioradores encontrados em frutas e verduras frescas. De acordo com Foley et al. (2003) a sanitização de produtos frescos com água ozonizada é uma excelente 
ferramenta para reduzir a população de microrganismos e parasitas da superfície destes o que reduz o risco de doenças sendo necessário avaliar a tolerância de frutas e hortaliças quanto à doses e tempos de exposição à água ozonizada.

\subsubsection{Utilização do ozônio na indústria de alimentos}

O uso de ozônio como agente antimicrobiano, sua aplicação no processamento e no armazenamento de alimentos e utilização na indústria, tem sido estudado há alguns anos. Dentre os alimentos examinados destacam-se as frutas e vegetais; os grãos em geral; a carne e seus derivados, assim como o pescado e seus derivados (CAVALCANTE, 2013).

Tiwari e Muthukumarappan (2012) citam a ação do ozônio como ferramenta de desinfecção em frutas e legumes (alface, maçã, coentro, cenoura, melão, batata, mirtilo, aipo, pepino). O principal propósito da ozonização de frutas e legumes, além da inativação de microrganismos patogênicos e deteriorantes, é a destruição de resíduos de pesticida e de outros produtos químicos. Em geral, o processo é feito com ozônio gasoso, lavagem com água ozonizada ou ainda em sucos de frutas.

O ozônio tem sido também utilizado, inclusive nas indústrias, para controlar o desenvolvimento de pestes (insetos e microrganismos em geral) em grãos armazenados, desinfetar farinhas e degradar moléculas potencialmente tóxicas (LULLIEN-PELLERIN, 2012). Kells et al. (2001) avaliaram a ação do ozônio sobre besouros e traças em milho e observaram uma taxa de mortalidade de $92 \%$.

O uso da ozonização na cadeia da carne também pode ser na fase gasosa ou aquosa (POHLMAN, 2012). Castillo, (2003) avaliaram o impacto da lavagem de carcaças com spray de água ozonizada comparando com água não ozonizada. As carcaças foram contaminadas com E. coli e S. typhimurium. Os resultados foram parecidos, porém a pressão usada na lavagem com água não ozonizada foi bem superior. O uso do ozônio na carne pode provocar perdas da característica normal como a coloração vermelha, conferida pela oximioglobina, a qual é oxidada a metamioglobina, ocasionando coloração mais escura à carne. Da mesma forma, a oxidação dos lipídios de cadeia dupla também pode ocorrer (POHLMAN, 2012).

O ozônio é utilizado para a esterilização de equipamentos e da área de produção, a desinfecção de embalagens, a redução da carga microbiana da água usada para resfriamento de frangos, o tratamento de frutas e hortaliças visando aumento da vida de 
prateleira, o combate a biofilmes microbianos localizados em superfícies de metais, entre outros (PIRANI, 2011).

A utilização do gás sobre o leite fluido produz redução nas contagens de microrganismos aeróbios mesófilos enterobactérias, psicotróficos, S. aureus, bolores e leveduras foi observado por um período de 10 minutos, onde ocorreu uma significativa redução destes microrganismos. A partir da aplicação por 15 minutos observou-se reduções significativas de 0.60 ciclos $\log , 0.96$ ciclos $\log , 0.13$ ciclos $\log , 1.02$ ciclos log e 0.48 ciclos log para aeróbios mesófilos, Enterobacteriaceae, psicrotróficos, Staphylococcus spp., e bolores e leveduras, respectivamente (CAVALCANTE et al., 2013; COUTO et al., 2016).

Utilizando 5, 10 e 15 minutos, Sheelamary e Muthukumar (2011) estudaram os efeitos da ozonização sobre a população de L. monocytogenes em amostras de leite e observaram que a partir de 10 minutos o efeito antimicrobiano do ozônio foi eficiente, pois, houve eliminação total do microrganismo.

Lanita e Silva (2008) compararam três tratamentos com ozônio no controle de bolores e leveduras em queijo tipo parmesão, em condições industriais. Foram realizados tratamentos apenas com ozônio, ozônio e lavagem dos queijos e, lavagem e aplicação de fungistático natamicina. Como resultado, as médias das contagens aos 60 dias do tratamento 2 foram significativamente superiores às dos outros tratamentos. Serra et al. (2003) verificaram a ação fungicida do ozônio em sala de maturação de queijo, tanto no ar quanto em superficies. Os tratamentos reduziram os bolores do ar, mas não afetaram a viabilidade dos bolores nas superfícies.

Segundo Cullen e Norton (2012) uma das primeiras pesquisas com ozônio na indústria de leite foi realizada por Greene et al. (1993), o qual compararam a efetividade da água ozonizada com um sanitizante clorado para desinfecção de superfícies de metal contaminadas com leite UHT inoculado com colônias de Pseudomonas fluorescens e Alcaligenes faecalis, e concluíram que ambos os tratamentos tiveram alta eficiência, com 99\% de redução da microbiota.

Güzel-Seydim et al. (2000) estudaram o uso de água ozonizada a $10^{\circ} \mathrm{C}$, como técnica de limpeza prévia de superfície metálica comum em equipamentos da indústria de laticínios, comparando com a limpeza convencional, que é feita com água aquecida a $40^{\circ} \mathrm{C}$. As taxas de remoção foram de $84 \%$ dos resíduos de leite pela água ozonizada, enquanto a água morna removeu $51 \%$. 


\section{REFERÊNCIAS}

AAKU, E. N.; COLLISON, E. K.; GASHE, B. A.; MPUCHANE, S. Microbiological quality of milk from two processing plants in Gabarone Botswana. Food Control, v. 15, p. 181186, 2004.

ABADIAS, M.; USALL, J.; ANGUERA, M.; SOLSONA, C.; VIÑAS, I. Microbiological quality of fresh, minimally-processed fruit and vegetables and sprouts from retail establishments. International Journal of Food Microbiology, v.123, n.1-2, p. 121-129, 2008.

ABREU, A. S.; Leite instável não ácido e propriedades físico-quimicas do leite de vacas Jersey. (Dissertação) Mestrado em Zootecnia - Universidade do Rio Grande de Sul, p.106, Fevereiro, 2008.

ACTON, D. S.; PLAT-SINNIGE, M. T.; VAN WAMEL, W.; DE GROOT, N; VAN BELKUM, A. Intestinal carriage of Staphylococcus aureus: how does its frequency compare with that of nasal carriage and what is its clinical impact? European Journal of Clinical Microbiology \& Infectious Diseases, v. 28, n. 2, p. 115-127, 2009.

ADACHI, D. Virus inactivation by ozone. (Dissertação) mestrado - Universidade de Toronto, p.122, 2001.

AJLOUNI, S.; SIBRANI, H.; PREMIER, R.; TOMKINS, B. Ultrasonication and fresh produce (Cos lettuce) preservation. Journal of Food Science, v.71, n.2, p. 62-68, 2006.

AKBAS, M.Y.; ÖLMEZ, H. Effectiveness of organic acid, ozonated water and chlorine dippings on microbial reduction and storage quality of fresh-cut iceberg lettuce. Journal of the Science of Food and Agriculture, v. 87, n.14, p. 2609-2616, $2007 \mathrm{~b}$.

.Inactivation of Escherichia coli and Listeria monocytogenes on iceberg lettuce by dip wash treatments with organic acids. Letters in Applied Microbiology, v.44, n.66, p.619-624, 2007a.

ALENCAR, E. R. Processo de ozonização de amendoim (Arachis hypogaea L.): cinética de decomposição, efeito fungicida e detoxificante de aflatoxinas e aspectos qualitativos, (Tese) doutorado, Universidade Federal de Viçosa, p. 107, 2009.

AL-GALLAS, N.; BAHRI, O.; AISSA, R. B., Prevalence of Shiga Toxi-Producing Escherichia coli, and the report of Isolation STEC O157:H7 in Tunis. Current Microbiology, v. 53, n.6, p. 483-490, 2006. 
ALLENDE, A.; SELMA, M.V.; LÓPEZ-GÁLVEZ, F.; GIL, M.I. Impact of wash water quality on sensory and microbial quality, including Escherichia coli cross-contamination, of fresh-cut escarole. Journal of Food Protection, v.71, p.2514-2518, 2008.

ALVARO, J. E.; MORENO, S.; DIANEZ, F.; SANTOS, M.; CARRASCO, G.; URRESTARAZU, M. Effects of peracetic acid disinfectant on the postharvest of some fresh vegetables. Journal of Food Engineering, v. 95, n.1, p.11-15, 2009.

AMARAL, L. A.; ROSSI JÚNIOR, O. D.; NADER FILHO, A., FERREIRA, F. L. A.; e BARROS, L. S. S. Ocorrência de Staphylococcus sp. em água utilizada em propriedades leiteiras do Estado de São Paulo. Arquivo Brasileiro de Medicina Veterinária e Zootecnia, v. 55, n. 5, p. 620-623, 2003.

ANDRADE, N. J. de. Higiene na indústria de alimentos: avaliação e controle da adesão e formação de biofilmes bacterianos. São Paulo: Varela, p. 412, 2008.

; PINTO, C. L. D. O.; LIMA, J.C. Adesão e formação de biofilmes microbianos. In. ANDRADE, N.J. (Ed.) Higiene na Indústria de Alimentos: Avaliação e controle da adesão e formação de biofilmes bacterianos. São Paulo: Varela, p.15-66, 2008.

ANDRADE, R. R. et al. Ocorrência e diferenciação de espécies de Listeria spp. em salsichas tipo hot dog a granel e em amostras de carne moída bovina comercializadas no Distrito Federal. Ciência Rural, v. 44, n. 1, p. 147-152, 2014.

ANNUK, H.; SHCHEPETOVA, J.; KULLISAAR, T.; SONGISEPP, E.; ZILMER, M.; MIKELSSAAR, M. (2003). Characterization of intestinal lactobacilli as putative probiotic candidates. Journal of Applied Microbiology, v. 94, n. 3, p. 403-12, 2003.

ARGOV, N, LEMAY, D.G., GERMAM, J.G. Milf fat globule structure and function: nanoscienc comes to milk production. Trends in food science \& technology, v.19, n. 12, p. 617-623, 2008.

AXELSSON, L. Lactic acid bacteria: classification and physiology. In: SALMINEN, S.; VONWRIGHT, A. Lactic acid bacteria. New York: Marcel Dekker, p. 1-63, 1993.

AXELSSON, L.; AHRNÉ, S. Lactic acid bacteria. In: Applied microbial systematics Edited by: PRIEST, F.G.; GOODFELLOW, M.; DORDRECHET, The Netherlands: Kluwer Academic Press; p. 365-386, 2000.

AZAM, F., and MALFATTI, F. Microbial structuring of marine ecosystems. Nature Reviews Microbiology, v.5, p. 782-792, 2007. 
BARBALHO, T. C.; ALMEIDA, P. F.; ALMEIDA, R. C.; HOFER, E. (2005). Prevalence of Listeria spp. at a poultry processing plant in Brazil and a phage test for rapid confirmation of suspect colonies. Food Control, v. 16, n. 3, p. 211-216, 2005.

BARROS, M. A. F.; NERO, L. A.; SILVA, L. C. et al. Listeria monocytogenes: Occurrence in beef and identification of the main contamination points in processing plants. Meat Science, v. 76, p. 591-596, 2007.

BECKER, K.; SKOV, R. L.; VON EIFF, C. Staphylococcus, Micrococcus, and other catalasepositive cocci. In: Manual of Clinical Microbiology, Eleventh Edition. American Society of Microbiology, p. 354-3822015.

BAUMAN, D.E.; LOCK, A.L. Concepts in lipid digestion and metabolism in dairy cows. In: TRI-STATE DAIRY NUTRITION CONFERENCE，2007, Ohio. Proceedings... Ohio: Ohio State University, p.1-14. 2006.

BELTRAME, C. A. et al. Influence of different sanitizers on food contaminant bacteria: effect of exposure temperature, contact time, and product concentration.Ciência e Tecnologia de Alimentos, Campinas, v. 32, n. 2, p. 228-233, abr./jun. 2012. Disponível em: <http://www.scielo.br/pdf/cta/v32n2/aop4668.pdf>. Acesso em: 21 set 2014.

BIALKA, K. L.; DEMERCI, A. Utilization of gaseous ozone for the decontamination of Escherichia coli O157:H7 and Salmonella on raspberries and strawberries. Journal of Food Protection, v. 70, n. 5, p. 1093-1098, 2007.

BLANCO, M. et al. Serotypes, virulence genes, and intimin types of Shiga toxin (verotoxin)producing Escherichia coli isolates from cattle in Spain and identification of a new intimin variant gene (eae- $\xi$ ). Journal of Clinical Microbiology, v. 42, n. 2, p. 645-651, 2004.

BONDAN, C. Fatores que afetam a composição do leite bovino em rebanhos sob controle leiteiro: um enfoque epidemiológico e metabólico. (Tese) Doutorado, Universidade Federal do Rio Grande de Sul. Faculdade de Veterinária, p. 106, Porto Alegre, 2015.

BONIFAIT, L.; CHANDAD, F.; GENIER, D. Proboitics for oral health: Myth reality. Jornal of the Canadian Dental Association. v. 75, n.8, p. 585-590, 2009.

BOPP, D. J.; et al. Detection, isolation, and molecular subtyping of Escherichia coli O157:H7 and Campylobacter jejuni associated with a large waterborne outbreak. Journal of Clinical Microbiology, v. 41, n. 1, p. 174-180, 2003.

BRASIL, Portaria n 2914 de 14 de dezembro de 2011. Dispõe sobre os procedimentos de controle e de vigilância da qualidade da água para consumo humano e seu padrão de potabilidade. Diário Oficial da União. Brasília. DF. 14 dez. 2011. 
BRASIL. Ministério da Agricultura, Pecuária e Abastecimento - MAPA. Instrução Normativa no 62, de 29 de dezembro de 2011. Regulamento Técnico de Produção, Identidade e Qualidade do Leite tipo A, Identidade e Qualidade de Leite Cru Refrigerado, Identidade e Qualidade de Leite Pasteurizado e Coleta de Leite Cru Refrigerado e seu Transporte a Granel. Diário Oficial da União. Brasília. DF 29 Dez. 2011.

BRASIL. Ministério de Estado da Agricultura, Pecuária e abastecimento. Portaria n. 370, de 4 de setembro de 1997. Regulamento técnico para fixação de identidade e qualidade do leite UHT (UAT). Diário Oficial da República Federativa do Brasil, Brasília, n. 172, 8 set. 1997a. Seção I. 1997.

BREMER, P. J.; FILLERY, S. E.; MMCQUILLAN, A. J; Laboratory scale Clean-In-Place (CIP) studies on the effectiveness of different caustic and acid wash steps on the removal of dairy biofilms. International Journal of Food Microbiology, v. 106, n. 3, p. 254$262,2006$.

BRITO, J. R. F.; PINTO, S. M.; SOUZA, G. N.; ARCURI, E. F.; BRITO, M. A. V. P.; e SILVA, M. R Adoção de boas práticas agropecuárias em propriedades leiteiras da Região Sudeste do Brasil como um passo para a produção de leite seguro. Acta Scientiae Veterinariae, v. 32, n. 2, p. 125-131, 2004.

BURITI, F. C. A.; SAAD, S. M. I. Bactérias do grupo Lactobacillus casei: caracterização, viabilidade como probióticos em alimentos e sua importância para a saúde humana. Archivos Latino americanos de Nutrición, v.57, p.373-380 2007.

CAO, S.; HU, Z.; PANG, B.;WANG, H.; XIE, H.; WU, F. Effect of ultrasound treatment on fruit decay and quality maintenance in strawberry after harvest. Food Control, v. 21, n. 4, p. 529-532, 2010.

CARR, F. J.; CHILL, D.; MAIDA, N. The acid lactic bacteria: A literature survey. Critical Reviews in Microbiology, v. 28, n. 4, 2002.

CASANOVA, J.L.; ABEL, L. Genetic dissection of im-munity to mycobacteria: The human model. Annual review of immunology, v. 20, n. 1, p. 581-620, 2002.

CASTILLO, A. Ozone treatment for reduction of Escherichia coli O157:H7 and Salmonella serotype typhimurium on beef carcass surfaces, Journal of Food Protection, v. 66, n. 5, p. $775-779,2003$.

CATALDO, F. On the action of ozone on proteins. Polymer Degradation and Stability, v. 82, p. 105-14, 2003. 
CAVAlCANTE, D. A.; LEITE JÚNIOR, B. R. D. C.; TRIBST, A. A. L.; CRISTIANINI, M. Shelf life evaluation of the iceberg lettuce sanitized with ozone water. Ciência Rural, v. 45, n. 11, p. 2089-2096, 2015.

\section{OZÔNIO GASOSO NA SANITIZAÇÃO DE CÂMARAS}

FRIGORÍFICAS. Revista Instituto Laticínios Cândido Tostes, Juiz de Fora, v. 69, n. 2, p. 121-128, mar/abr, 2014.

; COELHO, V. R. P. Uso da água ozonizada na sanitização dos tetos de bovinos e sua influência na qualidade do leite. Revista do Instituto de Laticínios Cândido Tostes, v. 68, n. 392, p. 33-39, 2013.

CAVALCANTE, M. A. Improvement of the raw milk microbiological quality by ozone treatment. International Food Research Journal, v. 20, n. 4, p. 2017-2021, 2013.

CHEMAT, F. and KHAN, M. K. Applications of ultrasound in food technology: Processing, preservation and extraction. Ultrasonic Sonochemistry, v.18, n.4, p.813-835, 2011.

CHEN, Y.; WANG, H.; XU, Y.; WU, J.; XIAO, G.Effect of treatment with dimethyl dicarbonate on microorganisms and quality of Chinese cabbage. Postharvest Biology and Technology, v.76, p.139-144, 2013.

CHEN, Z.; ZHU, C. Combined effects of aqueous chlorine dioxide and ultrasonic treatments on postharvest storage quality of plum fruit (Prunus salicina L.). Postharvest Biology and Technology, v. 61, n.2-3, p.117-123, 2011.

CHMIELEWSKI, R. A. N.; FRANK, J. F. Biofilm formation and control in food processing facilities. Comprehensive Reviews in: Food Science and Food Safety, v. 2, n. 1, p. 22 32, 2003.

CLESCERI, L.S.; GREENBERG, A.E. EATON, A.D. Standard methods for the examination of water and wastewater. Denver: American Water Works Association, p. $1220,2000$.

COLAGIORGI, A.; DI CICCIO, P.; ZANARDI, E.; GHIDINI, S.; IANIERE, A. A Look inside the Listeria monocytogenes Biofilms Extracellular Matrix. Microorganisms v.4, n. 3, p. 22, 2016.

CORDANO, A.M.; JACQUET, C. Listeria monocytogenes isolated from vegetable salads sold at supermarkets in Santiago, Chile: prevalence and strain characterization. International journal of food microbiology, v. 132, n. 2, p. 176-179, 2009.

COSTA, E. N. Influência do tratamento térmico sobre os ácidos graxos do leite bovino. (Dissertação) Mestrado - Programa de Pós-Graduação em Engenharia de Alimentos da 
Universidade Estadual do Sudoeste da Bahia - UESB - Campus de Itapetinga, p. 46, 2011.

COUTO, E. P.; ALENCAR, E. R.; GONÇALVES, V. S. P., dos SANTOS, A. J. P., RIBEIRO, J. L., de AGUIAR FERREIRA, M. Efeito da ozonização sobre a contagem da Staphylococcus Aureus inoculado em leite. Semina: Ciências Agrárias, v. 37, n. 4, p. 1911-1918, 2016.

COUTO, E. P. Monitoramento dos principais pontos críticos de controle no beneficiamento e envase do leite em laticínios do Distrito Federal. (Monografia) - Universidade de Brasília/Faculdade de Agronomia e Medicina Veterinária, 47 p. 2011.

CULLEN, P. J.; NORTON, T. Ozone sanitisation in the food industry. In: O'DONNELL, C. P., et al. Ozone in Food Processing, $1^{\text {a }}$ ed., Blackwell Publishing, 2012.

DA MATTA JÚNIOR, M. D. Características estruturais, físico-químicas e funcionais dos amidos de mandioca e de milho com diferentes teores de amilose oxidados por ozônio. Tese (Doutorado). Escola Superior de Agricultura Luiz de Queiroz, p.125, 2015.

DEL GIORGIO, P. A., and Cole, J. J. Bacterial growth efficiency in natural aquatic systems. Annual Review of Ecology and Systematics, v.29, p. 503-541, 1998.

DE PAULA, C. L.; MIONIL, M. S. R.; APPOLINÁRIO, C. M.; KATAYAMA, E. R.; ALLENDORF, S. D.; MEGID, J. Detecção de Brucella spp. em leite bovino não pasteurizado através da Reação de Cadeia pela Polimerase (PCR). Arquivos do Instituto Biológico, São Paulo, v.82, p.1-5, 2015.

DI BERNARDO, L. e DANTAS, A. D. B. Métodos e técnicas de tratamento de água. São Carlos: Rima, v. 2, 784 p, 2005.

DOYLE, M. P. Escherichia coli O157: H7 and its significance in foods. International Journal of Food Microbiology, v. 12, n. 4, p. 289-301, 1991.

DUMALISILE, P.; WITTHUHN, R. C.; BRITZ, T. J. Impact of different pasteurization temperatures on the survival of microbial contaminants isolated from pasteurized milk. International Journal of Dairy Technology, v. 58, n. 2, p. 74-82, 2005.

DUNNE, W.M. Bacterial adhesion: seen any good biofilms lately? Clinical Microbiology Reviews, v.15, p. 155-166, 2002.

DÜRR, J. W. Programa nacional de melhoria da qualidade do leite: uma oportunidade única. In: DÜRR, J. W.; CARVALHO, M. P.; SANTOS, M.V. (Eds.) O compromisso com a qualidade do leite no Brasil. Passo Fundo: Editora Universidade de Passo Fundo, p. 38-55, 2004. 
; RIBAS, N. P.; COSTA,C. N.; HORST, J. A.; BONDAN, C. Milk recording as an indispensable procedure to assure Milk quality. Revista Brasileira de Zootecnia, $\begin{array}{lllll}\text { Viçosa, } & \text { v. } & 40, & \text { p. } & 76-81,\end{array}$ http://www.agricultura.pr.gov.br/arquivos/File/deral/Prognosticos/bovinocultura_leite_14 15.pdf.

ECDC. Euro surveillance editorial team. The European Union summary report on trends and sources of zoonoses, zoonotic agents and food-borne outbreaks in 2010. Euro Surveill., v. $17, \quad$ n. $10,2012 . \quad$ Disponível em: <http://www.eurosurveillance.org/ViewArticle.aspx?ArticleId=20113>. Acesso em: 15 abr.2014.

EUZÉBY, J.P. List of bacterial names with standing in nomenclature. Disponível em: <http://www.bacterio.cict.fr/s/staphylococcus.html $>$. On line. Acesso em: 06 set. 2015.

FAGAN, E. P.; BELOTI, V.; BARROS, M. A. F.; MUlleR, E. E.; NERO, L. A.; SANTANA, E. H. W.; MAGNANI, D. F.; VACARELLI, E. R.; SILVA, L. C.; PEREIRA, M. S. Evaluation and implementation of good practices in main points of microbiological contamination in milk production. Semina: Ciências Agrárias, Londrina, v. 26, n. 1, p. 81-90, jan./mar. 2005.

FARJALLA, V. F.; ESTEVES, F. A.; BOZELLI, R. L.; ROLAND, F. Nutrient limitation of bacterial production in clear water Amazonian ecosystems. Hydrobiologia, v. 489, n. 13, p. 197-205, 2002.

FERREIRA, M. A. Controle de qualidade físico-química em leite fluido. Brasília: Universidade de Brasília, p. 20, Dossiê Técnico. 2007.

FERREIRA, N. D. L.; FERREIRA, S. H. F.; MONTE, A. L. S.; VASCONCELOS, N. L. Avaliação das condições sanitárias e físico-químicas do leite informal consumido em Sobral, Ceará. Higiene Alimentar, v.17, n. 108, p. 79-82, Mai, 2003.

FERRETTI, R.; MANNAZZU, I.; COCOLIN, L.; COMI, G.; CLEMENTI, F. Twelve-hour PCR-based method for detection of Salmonella spp. in food. Applied and Environmental Microbiology, v. 67, n. 2, p. 977-978.2001.

FLEMING, D. W, et al. Pasteurized milk as a vehicle of infection in an outbreak of listeriosis. New England journal of medicine, v. 312, n. 7, p. 404-407, 1985.

FRANCO, B. D. G. M. e LANDGRAF, M. Microbiologia dos alimentos. São Paulo: Ateneu, p. 182, 2008.

FREITAS, F. E. G.; FERREIRA, M. R.; PINTO, J. F.; CONCEIÇÃO, F. R.; MOREIRA, C. N. Enterohemorrhagic Escherichia coli O157: H7 from healthy dairy cattle in Mid-West 
Brazil: occurrence and molecular characterization. Pesquisa Veterinária Brasileira, v. 34, n.1, p. 24-28, 2014.

FOLEY, G.J.; GEORGPOUlOS, P.G.; LIOY, P.J. Accountability within new ozone standards. Environmental Science \& Technology, v. 37, n. 21, p. 392A-399A, 2003.

FORTUNA, J. L.; NASCIMENTO, E. R.; e FRANCO, R. M. Correlação entre contagem de bactérias heterotróficas aeróbias mesófilas e isolamento de Salmonella spp. em hambúrgueres crus. Revista Brasileira de Ciência Veterinária, v. 20, n. 1, p. 59-63, jan./mar. 2013.

FUKUSHIMA, H.; HOSHINA, K.; GOMYODA, M. Selective isolation of eae positive strains of shiga toxin-producing Escherichia coli. Journal of Clinical Microbiology, v. 38, n.4, p. 1684-87, 2000.

GARCÍA-ZAPATA, L. Producción de bacteriocinas de bacterias lácticas aisladas de encurtidos. (Monografia) - Faculdade de Ciências Experimentais - Biologia, p. 48, 2016 .

GOGATE, P. R.; PANDIT, A. B. A review of imperative technologies for wastewater treatment II: hybrid methods. Advances in Environmental Research, Oxford, v. 8, n. 3 4, p. 553-597, Mar, 2004.

GOH, S.G. et al. Listeria monocytogenes in retailed raw chicken meat in Malaysia. Poultry Science, v.91, n.10, p.2686-2690. Disponível em: <http://eutils.ncbi.nlm.nih.gov/entrez/eutils/elink.fcgi?dbfrom=pubmed\&id=22991558\&r etmode=ref\&cmd=prlinks $>$. Acesso em: 15 out. 2014. doi: 10.3382/ps.2012-02349. 2012. GÓMEZ-LÓPEZ, V. M.; ORSOLANI, L.; MARTÍNEZ-YÉPEZ, A.; TAPIA M. S.; Microbiological and sensory quality of sonicated calcium-added orange juice. LWT Food Science and Technology, v. 43, n. 5, p. 808-813, 2010.

GOPAL, A.; COVENTRY, J.; WAN, J.; ROGINSKI, H.; AJLOUNI, S. Alternative disinfection techniques to extend the shelf life of minimally processed iceberg lettuce. Food Microbiology, v. 27, n.2, p.210-219, 2010.

GOTTSCHALK, C.; LIBRA, A. J.; SAUPE, A. Ozonation of Water and WasteWater: A Practical Guide to Understanding Ozone and its Applications, 2 ${ }^{\mathrm{a}}$ ed., 2000.

GRADELLA, A. N. Aspectos nutricionais e de qualidade do leite. (Monografia)Especialização em Higiene e Inspeção de Produtos de Origem Animal. Universidade Federal de São Carlos - São Paulo, p.36, Fevereiro/2008. 
GRAÇA, A.; ABADIAS, M.; SALAZAR, M.; NUNES, C. The use of electrolyzed water as a disinfectant for minimally processed apples. Postharvest Biology and Technology, v. 61, n. 2-3, p. 172-177, 2011.

GREENE, A. K.; GUZEL-SEYDIM, Z. B.; SEYDIM, A. C. Chemical and physical properties of ozone. In: O’DONNELL, C. P., et al. Ozone in Food Processing, $1^{\text {a }}$ ed., Blackwell Publishing, 2012.

A comparison of ozonation and chlorination for the disinfection of stainless steel surfaces. Journal of Dairy Science, v. 76, n.11, p. 3617-3620, 1993.

; SMITH, G.W.; KNIGHT, C. S. Ozone in dairy chilling water systems. International Journal Dairy Technology, v. 52, n. 4, p. 126-128, 1999.

GUERRERO, S.; LÓPEZ-MALO, A.; ALZAMORA, S.M. Effect of ultrasound on the survival of Saccharomyces cerevisiae: influence of temperature, $\mathrm{pH}$ and amplitude. Innovative Food Science an Emmerging Technologies, v. 2, n. 1, p. 31-39, 2001.

GUZEL-SEYDIM, Z. B.; GREENE, A. K.; SEYDIM, A. C. Use of ozone in the food industry. Use of ozone in the food industry. LWT-Food Science and Technology, v. 37, n. 4, p. 453-460, 2004.

HALL, E. K. and COTNER, J.B. Interactive effect of temperature and resources on carbon cycling by freshwater bacterioplankton communities. Aquatic Microbial Ecology, v. 49, n.1, p. 35-45, 2007.

HARRIS, L. G.; FOSTER, S. J.; RICHARDS, R. G. An introduction to Staphylococcus aureus, and techniques for identifying and quantifying $S$. aureus adhesins in relation to adhesion to biomaterials: review. European Cells and Material, v. 4, n. 3, p. 39-60, 2002.

HASSAN, A. N.; FRANK, J. F. Starter cultures and their use. In: MARTH, E. H.; STEELE, J. L. (Ed.). Applied Dairy Microbiology. 2. ed. New York: Marcel Decker, 2001.

HILL, A.G. and RICE, R.G. Historical background, properties and applications, in Rice, R.G. and Netzer, A. (editores) Handbook of Ozone Technology and Applications, v. 1, Ann Arbor Science Publishers, p. 1-37, 1982.

HUNT, N. K.; MARIÑAS, B. J. Inactivation of Escherichia coli with ozone: chemical and inactivation kinetics. Water Research, Kidlington, v. 33, n. 11, p. 2633-2641, 1999.

HUSSIEN, H.; MAHROUS, E. Isolation and molecular characterization of Mycobacterium tuberculosis complex isolated from raw milk in some dairy farms in Egypt. International Journal of Basic and Applied Sciences, v. 5, n. 2, p. 105, 2016. 
HUTKINS, R.W. Microbiology and technology of fermented foods ( $1^{\text {st }}$ ed.), 473 pp., Oxford, Blackwell Publishing, p. 207 - 232 - ISBN: 9780813800189, 2006.

IBANOGLU, S. Influence of tempering with ozonated water on the selected properties of wheat flour. Journal of Food Engineering, v. 48, n. 4, p. 345-350, 2001.

INÊS, A. F. H. Abordagem polifásica na caracterização e seleção de bactérias do ácido lático de vinhos da região Demarcada do Douro. (Tese) Doutorado em Microbiologia. Universidade de Trás-os-Montes e Alto Douro, Vila Real, 198 f. 2007.

; TENREIRO, T.; TENREIRO, R.; FAIA, M. As Bactérias do Ácido Láctico do vinho. Revisão: as bactérias do ácido láctico do vinho-Parte I. Ciência e técnica vitivinícola, v. 23, n. 2, p. 81-96, 2008.

JACQUES, A. C.; ZAMBIAZI, R. C.; GANDRA, E. Á.; KRUMREICH, F.; LUZ, S. R.; MACHADO, M. R. G. Sanitização com produto à Base de Cloro e com Ozônio: Efeito Sobre Compostos Bioativos de Amora-preta (rubus fruticosus) cv. Tupy. Revista Ceres, Viçosa, v. 62, n.6, p. 507-509, nov-dez, 2015.

JAY, J. M. Microbiologia de alimentos. $6^{\text {a }}$ Ed. Porto Alegre: Artmed, 2005.

KAPER, J. B.; NATARO, J. P.; MOBLEY, H. L. Pathogenic escherichia coli. Nature Reviews Microbiology, v. 2, n. 2, p. 123-140, 2004.

, GANSHEROFF, M. R. W.; O'BRIEN, A. D. Intimin-mediated adherence of shiga toxin-producing Escherichia coli and attaching-and-effacing pathogens. In: KAPPER, J.B. and O'BRIEN, A.D. Escherichia coli O157:H7 and other shiga toxinproducing Escherichia coli strains. Washington: ASM PRESS, p. 148-156, 1998.

KAPLAN, J. B.; RAGUNATH, C.; VELliYAGOUBDER, K.; FINE, D. H.; E RAMASUBBU, N. Enzymatic detachment of Staphylococcus epidermidis biofilms. Antimicrobial agents and chemotherapy, v. 48, n.7, p. 2633-2636, 2004.

KARMALI, M. A. Infection by verocytotoxin-producing Escherichia coli. Clinical Microbiology Reviews, v. 2, n.1, p. 15-38, 1989.

KASNOWSKI, M. C.; MANTILlA, S. P. S.; OLIVEIRA, L. A. T.; FRANCO, R. M. Formação de biofilme na indústria de alimentos e métodos de validação de superfícies. Revista Científica Eletrônica de Medicina Veterinária, n. 15, p. 1-23, 2010.

KECHINSKI, C. P. Avaliação do uso de ozônio e de outros tratamentos alternativos para a conservação do mamão papaia (Carica papaya L.) (Dissertação) Mestrado - Faculdade de Engenharia Química, Universidade Federal do Rio Grande do Sul, Porto Alegre, p. $125,2007$. 
KELLS, S. A.; MASON, L. J.; MAIER, D. E.; WOLOSHUK, C. P. Efficacy and fumigation characteristics of ozone in stored maize, Journal of Stored Products Research, v. 37, n. 4, p. 371-82, 2001.

KHADRE, M. A.; YOUSEF, A. E.; KIM, J. G. Microbiological Aspects of Ozone Applications in Food: A Review. Journal of Food Science, v. 66, n. 9, p. 1242-1252, 2001.

KIM, J. G.; YOUSEF, A. E.; DAVE, S. Application of ozone for enhancing the microbiological safety and quality of foods: a review. Journal of Food Protection, v. 62, n. 9 , p. 1071-1087, 1999.

2000. Inactivation Kinetics os Foodborne Spoilage and Pathogenic Bacteria by Ozone in: Journal of Food Science, v. 65, n. 3, p. 521-528, Lennetech Webpag 2013.

KLAENHAMMER, T. R.; BARRANGOU, R.; BUCK, B. L.; AZCARATE-PERIL, M. A.; ALETERMANN, E. Genomic features of lactic acid bacteria effecting bioprocessing and health. FEMS Microbiology Reviews, v. 29, n. 3, p. 393-409, 2005.

KODA, S.; MIYAMOTO, M.; TOMA, M.; MATSUOKA, T.; MAEBAYASHI, M. Inactivation of Escherichia coli and Streptococcus mutans by ultrasound at $500 \mathrm{kHz}$. Ultrasonics Sonochemistry, v.16, n.5, p. 655-659, 2009.

KUHNERT, P.; BOERLIN, P.; EMLER, S.; KRAWINKLER, M.; FREY, J. Phylogenetic analysis of Pasteurella multocida subspecies and molecular identification of feline $P$. multocida subsp. septica by 16S rRNA gene sequencing. International Journal Medical Microbiology, v. 290, n.7, p. 599-604, 2000.

LANGLAIS, B.; RECKHOW, D. A.; BRINK, D. R. Ozone in water treatment: application and engineering. Chelsea: AWWARF and Lewis Publishers, 1991. 568 p.

LANGONI, H. Qualidade do leite: utopia sem um programa sério de monitoramento da ocorrência de mastite bovina. Pesquisa Veterinária Brasileira, v. 33, n. 5, p. 620-626, 2013.

Aspectos microbiológicos e de qualidade do leite bovino. Pesquisa Veterinária Brasileira, vol. 31 n 12 Rio de Janeiro, p.1059-1065, Dec. 2011. ; SAKIYAMA, D. T. P.; GUIMARÃES, F. F., MENOZZI, B. D.; SILVA, R. C. Aspectos citológicos e microbiológicos leite em propriedades no sistema orgânico de produção. Pesquisa Veterinária Brasileira, v. 29, n. 11, p. 881- 886, 2009. 
LANITA, C. S.; SILVA, S. B. Uso de ozônio em câmara industrial para controle de bolores e leveduras durante a maturação de queijo tipo parmesão. Brazilian Journal of Food Technology, v. 11, n. 3, p. 182-189, 2008.

LAPOLLI, F. R. et al. Desinfecção de efluentes sanitários por meio da ozonização. In. GONÇALVES, R. F. (Coord.). Desinfecção de efluentes sanitários, remoção de organismos patógenos e substâncias nocivas: aplicação para fins produtivos como agricultura, aqüicultura e hidropônica, p. 169-208, Vitória- PROSAB, 2003.

LARA, V. M.; CARREGARO, A. B.; SANTURIO, D. F.; SÁ, M. F. D.; SANTURIO, J. M.; ALVES, S. H. Antimicrobial Susceptibility of Escherichia coli Strains Isolated from Alouatta spp. Feces to Essential Oils. Evidence-Based Complementary and Alternative Medicine, 2016.

LAZAROVA, V.; SAVOYE, P.; JANEX, M. Advanced wastewater disinfection technologies: state of the art and perspectives. Water Science Technology, London, v. 40, n. 4-5, p. 201-213, 1999.

LECUIT, M. Human Listeriosis and animal models. Microbes and Infeccion, v.9, p.12161225 2007.

Disponível

em: <http://www.sciencedirect.com/science/article/pii/S1286457907001852>. Acesso em: 28 ago. 2016.

LIMA, J. X.; OLIVEIRA, L. F. O crescimento do restaurante self-service: aspectos positivos e negativos para o consumidor. Revista Higiene Alimentar, v. 19, n. 128, p. 45-53, 2005 .

LINNAN, M. J. et al. Epidemic listeriosis associated with Mexican-style cheese. New England Journal of Medicine, v. 319, n. 13, p. 823-828, 1988.

LÓPEZ, D.; VLAMAKIS, H.; KOLTER, R. Biofilms. Cold Spring Harbor Perspectives in Biology, v. 2, p. 1-11, 2010.

LÜCKE, F. K. Utilization of microbes to process and preserve meat. Meat Science, v. 56, n. 2, p.105-115, 2000.

LULLIEN-PELLERIN, V. Ozone in grain processing. In: O'DONNELL, C. P., et al. Ozone in Food Processing, 1ª ed., Blackwell Publishing, 2012.

LIU, S.-Q. Practical implications of lactate and pyruvate metabolism by lactic acid bacteria in food and beverage fermentations. International Journal of Food Microbiology, v. 83, n. 2, p. 115-131, 2003. 
MACÊDO, J. A. B.; ANDRADE, N. J.; ARAÚJO, J. M. A. A.; CHAVES, J. B. P.; SILVA, M. T. C.; JORDÃO, C. P. Cloraminas orgânicas uma solução para evitar a formação de trihalometanos no processo de desinfecção de águas para o abastecimento público. Revista Higiene Alimentar, v. 15, n. 90 e 91, p. 93-103, 2001.

MACEDO, R.E.F.; Utilização de culturas láticas probioticas no processamento de produto cárneo fermentado. (Tese) Doutorado em tecnologia de Alimentos. Universidade Federal do Paraná, Curitiba, p. 205, 2005.

MADIGAN, M. T.; MARTINKO; J. M.; PARKER; J. Evolução e sistemática microbianas. In: MADIGAN. J. M.; PARKER; J. (Ed) Microbiologia da Brock. São Paulo: Prentice Hall, p. 304-330, 2004.

MAIA, G. B. S. et al. Produção Leiteira no Brasil. In: Inovação na indústria de alimentos: importância e dinâmica no complexo agroindustrial brasileiro. Agropecuária, BNDES Setorial, n. 37, p. 371-398, 2013.

MARTIN-DIANA, A. B.; RICOD, F. J.; MULCAH, J.; HENEHAN, G. T. M.; BARRYRYAN, C. Whey permeate as a bio-preservative for shelf life maintenance of fresh-cut vegetables. Innovative Food Science \& Emerging Technologies, v.7, n. 1, p. 112-123, 2006.

MASON, T.; RIERA, E.; VERCET, A.; LOPEZ-BUESA, P. Application of ultrasound. In: Sun, D.W. Editor, Emerging technologies for food processing, Elsevier Academic Press, California, p. 323-350, 2005.

MATTOS, M. R. et al. Qualidade do leite cru produzido na região do agreste de Pernambuco, Brasil. Semina: Ciências Agrárias, Londrina, v. 31, n. 1, p. 173-182, jan./mar. 2010.

MEDEIROS, R. S.; ARAÚJO, L. M.; QUEIROGA, N.V.; ANDRADE, P. P.; MELO, M. A.; GONÇALVEZ, M. M. B. P. Identification of lactic acid bacteria isolated from artisanal Coalho cheese produced in the Brazilian Northeast. CyTA-Journal of Food, p. 1-8, 2016.

MEDONLINE. Medicina on Line. Biofilme: um velho problema, uma nova batalha. Revista Virtual de Medicina. Disponível em <www.medonline.com.br>. Acesso em 6 de setembro de 2016.

DA SILVA, M. Q. C.; DE MEDEIROS, B. I.; ATHAYDE, A. J. A. A.; DE SILVEIRAJPUNIOR, J. P.; DE SOUZA, E. L. Influence of temperature and surface kind on biofilm formation by Staphylococcus aureus from food-contact surfaces and sensitivity to sanitizers. Food Control, v. 25, n. 2, p. 469-475, 2012. 
MESQUITA, M. O. de; FRIES, L. L. M.; VALENTE, T. Safety criteria for the acquisition of meat in Brazilian University restaurants. Food Science Technology, Campinas, v. 34, n. 1, p. 102-109, Mar. 2014.

MURRAY, P. R. Microbiologia Médica, 6ª edição. Elsevier, 2010.

NAGASE, N. et al. Isolation and species distribution of staphylococci from animal and human skin. Journal of Veterinary Medical Science, v. 64, n. 3, p. 245-250, 2002.

NAJAFI, M. B. H.; KHODAPARAST, M. H. Efficacy of Ozone to Reduce Microbial Populations in Date Fruits. Food Control, v. 20, n. 1, p. 27-30, 2009.

NASCIMENTO, L. C.; LIMA, L. C. O.; PICOLLI, R. H.; FIORINI, J. E. ; DUARTE, S. M. S.; SILVA, J. M. S. F.; OLIVEIRA, N. M. S.; VEIGA, S. M. O. M.. Ozônio e ultrassom: processos alternativos para o tratamento do café despolpado. Revista Ciência e Tecnologia de Alimentos, v. 28, n. 2, p. 282-294, 2008.

; VALLE, R.H.P. Uso de derivados clorados e ultra-som na sanitização de água e alimentos. Revista higiene alimentar. v. 36, n. 19, p. 48-57, 2005.

NASCIMENTO, M. S.; SILVA, N. Tratamentos químicos de sanitização de morango (Fragaria vesca L.). Brazilian Journal of Food Technology, v.13, n.1, p.11-17, 2010.

NATARO, J. P., KAPER, J. B. Diarrheagenic Escherichia coli. Clinical Microbiology Reviews, v. 11, n. 1, p. 142 - 201, 1998.

NEDER, et al. Presence of enterotoxigenic Staphylococcus aureus in bulk tank milk from Argentine dairy farms. Revista Argentina de Microbiología, v. 43, n.2, p.104-106, 2011.

NELSON, D. L.; COX, M. M. Lehninger princípios de bioquímica. 3.ed. São Paulo: Sorvier, p. 975, 2002.

NERO, L. A. Listeria monocytogenes e Salmonella spp. em leite cru produzido em quatro regiões leiteiras no Brasil: ocorrência e fatores que interferem na sua detecção. (Tese) Doutorado - Faculdade de Ciências Farmacêuticas da Universidade de São Paulo, Departamento de Alimentos e Nutrição Experimental, São Paulo, p. 141, 2005.

NG, D. L. and SEAH, H. L. Isolation and identification of Listeria monocytogenes from a range of foods in Singapore. Food Control, v.6, n. 3, p. 171-173, 1995.

O'CONNELL, J.E. and FOX, P.F. The two-stage coagulation of milk proteins in the minimum of the heat coagulation time-pH profile of milk: Effect of casein micelle size. Journal of dairy science, v. 83, n. 3, p. 378-386, 2000. 
O'DONNELL, C.; TIWARI, B. K.; CULLEN, P. J.; RICE, R. G. Status and trends of ozone in food processing. In: O’DONNELL, C. P.; TIWARI, B. K.; CULLEN, P. J.; RICE, R. G Ozone in Food Processing, p. 1-6. eds. Oxford: Wiley-BlackwelL, 2012.

OCHUA-HUESO, R. et al. Nitrogen deposition effect on Mediterranean-type ecosystems: An ecological assessment. Environmental Pollution, v. 159, n. 10, p. 2265-2279, 2011.

OLIVEIRA, M. N.; DAMIN, M. R. Efeito do teor de sólidos e da concentração de sacarose na acidificação, firmeza e viabilidade de bactérias do iogurte e probióticas em leite fermentado. Ciência e Tecnologia de Alimentos, v. 23, supl., p.172-176, 2003.

OLIVEIRA, M. M. M. de; BRUGNETRA, D. F.; PICCOLI, R. H. Biofilmes microbianos na indústria de alimentos: uma revisão. Revista do Instituto Adolfo Lutz (Impr.), São Paulo, v. 69, n. 3, 2010.

ÖLMEZ, H.; KRETZSCHMAR, U. Potential alternative disinfection methods for organic fresh-cut industry for minimizing water consumption and environmental impact. Food Science and Technology, v. 42, n. 3, p.686-693, 2009.

ONGENG, D.; DEVLIEGHERE, F.; DEBEVERE, J.; COOSEMANS, J. RYCKEBOER, J. The efficacy of electrolysed oxidising water for inactivating spoilage microrganisms in process water and on minimally processed vegetables. International Journal of Food Microbiology, v. 109, n. 3, p.187-197, 2006.

PACE, M.L.; PRAIRIE, Y.T. Respiration in lakes. In: del Giorgio PA, Williams PJB (eds) Respiration in aquatic ecosystems. Oxford University Press, New York, p. 103-121, 2005.

PAILLARD, D. et al. Rapid identification of Listeria species by using restriction fragment length polymorphism of PCR-Amplified 23S rRNA gene fragments. Applied and Enviromental Microbiology, v. 69, n.11, p. 6386-6392, 2003. Disponível em: <http://aem.asm.org/content/69/11/6386.full>. Acesso em 30 ago. 2014. doi: 0.1128/AEM.69.11.6386-6392.2003.

PALACIUS, T.; COULSON, S.; BUTT, H.; VITETTA, L. The gastrointestinal microbiota and multi-strain probiotic therapy: In children and adolescent obesity. Advances in Integrative Medicine, v. 1, n. 1, p. 2-8, 2014.

PARDO, R. B.; LANGONI, H.; MENDONÇA, L.J.P. Isolamento de Mycobacterium spp dp leite de vacas suspeitas e positivas para tuberculose. Brazilian Jornal of Veterinary Research and Animal Science. v. 38, n. 6, p. 284-287, 2001.

PARISH, M. E.; BEUCHAT, L. R.; SUSLOW, T. V.; HARRIS, L. J.; GARRET, E. H.; FARBER, J. N.; BUSTA, F. F. Methods to reduce/eliminate pathogens form fresh and 
fresh-cut produce. Comprehensive Reviews in Food Science and Food Safety, v. 2, n. 1, p. 161-173, (supplement), 2003.

PARIZZI; S. Q. F.; ANDRADE; N. J. de; SILVA; C. A. S.; SOARES; N. F. F.; SILVA; E. A. F. Bacterial adherence to different inert surfaces evaluated by epifluorescence microscopy and plate count method. Brazilian Archives of Biology Technology, v. 47, n. 1, p. 77-83, 2004.

PASCHOALATO, C. F. P. R.; TRIMAILOVAS, M. R.; BERNARDO, L. Formação de subprodutos orgânicos halogenados nas operações de pré-oxidação com cloro, ozônio e peroxônio e pós-cloração em água contendo substância húmica. Engenharia Sanitária e Ambiental, v. 13, n. 3, p. 313-22, 2008.

PASCUAL, A.; LLORCA, I.; CANUT, A. Use of ozone in food industries for reducing the environmental impact of cleaning and disinfection activities. Trends in Food Science \& Technology, v. 18, p. S29-S35, 2007.

PAVÓN, J. L. P.; MARTÍN, S. H.; PINTO, C. G.; CORDER, B. M. Determination of trihalomethanes in water samples: a review. Analytica Chimica Acta, v. 629, n. 1-2, p. 6-23, 2008.

PEHKONEN, A. The effect of dissolved ozone on the corrosion behavior of some stainless steels, (Dissertação) Mestrado - Helsinki University of Technology, Department of Materials Science and Rock Engineering, 2001.

PEREIRA, A. R.; ANGELOCCI, L. R.; SENTELHAS, P. C. Agrometeorologia: Fundamentos e aplicações práticas. Guaíba: Agropecuária, p. 478, 2002.

PEREIRA, M. T. C.; RIBEIRO, S. C. A.; CARVALHO, S. F. M. Revisão sobre o uso do ozônio no tratamento da mastite bovina e melhoria da qualidade do leite. Bioscience Journal, v. 19, n. 2, p. 109-114, 2003.

PEREIRA, D. A.; VIDOTTO, M. C.; NASCIMENTO, K. A.; SANTOS, A. C. R. D.; MECHLER, M. L.; OLIVEIRA, L. G. D. Virulence factors of Escherichia coli in relation to the importance of vaccination in pigs. Ciência Rural, v. 46, n. 8, p. 1430-1437, 2016.

PIETA, L.; CAMPOS, F. S.; MARIOT, R. F.; PRICHULA, J.; DE MOURA, T. M.; FRAZZON, A. P. G.; FRAZZON, J. Complete genome sequences of two Listeria monocytogenes serovars, $1 / 2 \mathrm{a}$ and $4 \mathrm{~b}$, isolated from dairy products in Brazil. Genome announcements, v. 3, n. 6, p. 01494-15, 2015.

PIRANI, S. Application of ozone in food industries. Doctoral Program in Animal Nutrition and Food Safety, Universita degli Studi di Milano, 2011. 
POHLMAN, F. W. Ozone in meat processing. In: O’DONNELL, C. P., et al. Ozone in Food Processing, $1^{\mathrm{a}}$ ed., Blackwell Publishing, 2012.

POMEROY, L. R. and WIEBE, W. J. Temperature and substrates as interactive limiting factors for marine heterotrophic bacteria. Aquatic Microbialogy Ecology, v. 23, n. 2, p. 187-2004, 2001.

POT, B.; DEVRIESE, L. A.; HOMMEZ, J.; MIRY, C.; VANDEMEULEBROECKE, K.; KERSTERS, K.; HAESEBROUK, F. Characterization and identification of Vagococcus fluvialis strains isolated from domestic animals. Journal of Applied Bacteriology, v. 77, n. 4, p. 362-369, 1994.

PRATA, L. F. Tratamentos térmicos aplicados ao leite. In: Fundamentos de ciência do leite. Jaboticabal, Unesp, p. 21-53, 2001.

PRESTES, E. B. Avaliação da eficiência do ozônio como sanitizante em hortaliças folhosas minimamente processadas. 2007. (Tese) - Doutorado em Tecnologia de Alimentos Universidade Estadual de Campinas, p. 135, Campinas.

QUINN, P. J.; MARKEY, B. K.; CARTER, M. E.; DONNELLY, W. J.; LEONARD, F. C. Microbiologia Veterinária e Doenças Infecciosas. Porto Alegre: Artmed, 2005.

RAHMAN, S. M. E.; JIN, Y-G.; OH, D. H. Combination treatment of alkaline electrolyzed water and citric acid with mild heat to ensure microbial safet, shelf life and sensory quality of shredded carrots. Food Microbiology, v. 28, n. 3, p. 484-491, 2011.

REID, G.; HEINEMANN, C.; VELRAEDS, M.; VAN DER MEI, H. C.; BUSSCHER, H. J. Biosurfactants produced by Lactobacillus. Methods in enzymology, v. 310, p. 426-433, 1999.

REIS; K. T. M.; GOLLNER, E. H. W. de S.; ROIG, S. M. Qualidade Microbiológica do Leite Cru e Pasteurizado Produzido no Brasil: Revisão. UNOPAR Científica Ciências Biológicas e da Saúde. Journal of Health Sciences, 2015.

RESTAINO, L.; FRAMPTON, E. W.; HEMPHILL, J. B.; PALNIKAR, P. Efficacy of ozonated water against various food-related microorganisms. Applied and Environmental Microbiology, v. 61, n. 9, p. 3471-3475, 1995.

RIBAS, L. C. M. Higienização de instalações e equipamentos em indústria de laticínios. Monografia (Especialização Lato Sensu em Higiene e Inspeção de Produtos de Origem Animal) - Universidade Castelo Branco, Goiânia, p.74, 2008.

RIBEIRO, M. E. R. et al. Ensaios preliminares sobre o efeito do leite instável não acido (LINA) na industrialização do iogurte batido. In: $9^{\circ}$ Congresso Brasileiro de Qualidade do Leite. Goiania - GO: Gráfica e Editora Talento, 2006. 
RICO, D.; MARTÍN-DIANA, A. B.; BARAT, J. M.; BARRY-RYAN, C. Extending and measuring the quality of fresh-cut fruit and vegetables: a review. Trends in Food Science and Technology, v. 18, n. 7, p. 373-386, 2007.

; BARRY-RYAN, C.; FRIAS, J. M.; HENEHAN, G. T. M.; BARAT, J. M.

Use of neutral electrolysed water (EW) for quality maintence and shelf life extension of minimally processed lettuce. Innovative Food Science and Emerging Technologies, v. 9, n. 1, p. 37-48, 2008.

RIETBERG, et al. SHORT REPORT Outbreak of Listeria monocytogenes infections linked to a pasteurized ice cream product served to hospitalized patients. Epidemiology and Infection. p. 1-4, 2015.

RIVERA-ESPINOZA, Y.; GALLARDO-NAVARRO, Y. Non-dairy probiotic products. Food Microbiology, v. 27, n. 1, p. 1-11, 2010.

RIYAZ-ULHASSAN, S.; VERMA, V.; QAZI. G. N. Rapid detection of Salmonella by polymerase chain reaction. Molecular and Cellular Probes, v. 18, p. 333-339, 2004.

RODRÍGUEZ, M. et al. Enzymatic hydrolyzed preparation of Saccharomyces cerevisiae: an additive with antibacterial potential for animal feeding. Cuban Journal of Agricultural Science, v. 49, n. 3, 2016.

ROJO-BEZARES, B.; SÁENZ, Y.; POETA, P.; ZARAZAGA, M.; RUIZ-LARREA, F.; TORRES, C. Assessment of antibiotic susceptibility within lactic acid bacteria strains isolated from wine. International Journal of Food Microbiology, v.111, n. 3, p. 234240, 2006.

RUÍZ-CRUZ, S.; FÉLIX, E. A.; CINCO, M. D. ; OSUNA, M. A. I.; AGUILAR, G. A. G. Efficacy of sanitizers in reducing Escherichia coli O157:H7, Salmonella spp. and Listeria monocytogenes populations on fresh-cut carrots. Food Control, v. 18, n. 11, p.13831390, 2007.

RYAN-BARRY, C.; MARTÍN-DIANA, A. B.; RICO, D. Grean tea extract as a natural antioxidant to extend the shelf-life of fresh-cut lettuce. Innovative Food Science and Emerging Technologies, v.9, n.4, p.593-603, 2008.

SAAD, N.; DELATTRE. C.; URDACI, M.; SCHMITTER, J.M.; BRESSOLLIER, P. An overview of the last advances in probiotic and prebiotic field. LWT - Food Science Technology, v. 50, n. 1, p. 1-16, 2013.

SABO, S. D. S.; VITOLO, M.; GONZÁLEZ, J. M. D.; OLIVEIRA, R. P. d. S. Overview of Lactobacillus plantarum as a promising bacteriocin producer among lactic acid bacteria.

Food Research International, v. 64, p. 527-536, 2014. 
SACCARO, D. M. Efeito da associação de culturas iniciadoras e probióticas na acidificação, textura e viabilidade em leite fermentado. 101 f. (Dissertação) - Mestrado em Tecnologia Bioquímico-Farmacêutica) - Faculdade de Ciências Farmacêuticas, Universidade de São Paulo, São Paulo, p. 101, 2008.

SALMINEN, S. et al. Demonstration of safety of probiotics - a review. International Journal of Food Microbiology, v. 44, n. 1, p. 93-106, 1998.

SANTANA, E. H. W. Determinação do perigo de consumo de leite cru relacionado à intoxicação estafilocócica. (Tese) Doutorado - Universidade Estadual de Londrina, Londrina, p. 74, 2006.

SANTO, M. L. P. E. Efeito da bacteriocinogenicidadedo Lactobacillus sakei 2a na qualidade microbiológica da sardinha-verdadeira (Sardinella brasiliensis) fermentada. (Tese) Doutorado em Ciências dos Alimentos - Programa de Pós-Graduação em Ciência dos Alimentos, Universidade Federal de Santa Catarina, p. 204, 2003.

SANTOS, A. J. P. Avaliação da utilização de ozônio como método de beneficiamento de leite. (Monografia) Universidade de Brasília, p.46, 2013.

SANTOS, M. V.; FONSECA, L. F. L. Estratégias para controle de mastite e melhoria da qualidade do leite. Barueri, SP: Ed. Manole, 2007.

SANTOS, R. L.; MARTINS, T. M.; BORGES, A.M.; PAIXÃO, T. A. Economic losses due to bovine brucellosis in Brazil. Pesquisa Veterinária Brasileira, v. 33, n. 6, p. 759-764, 2013.

SÃO JOSÉ, J. F. B.; VANETTI, M. C. D. Effect of ultrasound and commercial sanitizers on natural microbiota and Salmonella enterica Typhimurium on cherry tomatoes. Food Control, v. 24, n. 1-2, p. 95-99, 2012.

SCHELIN, J.; WALLIN-CARLQUIST, N.; COHN, M. T.; LINDQVIST, R.; BARKER, G. C.; RADSTROM, P. The formation of Staphylococcus aureus enterotoxin in food Environments and advances in risk assessment. Virulence, v. 2, n. 6, p. 580-592, 2011.

SCHLECH, W. F.; CHASE, D. P.; BADLEY, A. A model of food-borne Listeria monocytogenes infection in the Sprague-Dawley rat using gastric inoculation: development and effect of gastric acidity on infective dose. International Journal of Food Microbiology, v. 18, n. 1, p. 15-24, 1993.

SCHMID, B.; KLUMPP, J.; RAIMANN, E.; LOESSNER, M. J.; STEPHAN, R.; TASARA, T. Role of cold shock proteins in growth of Listeria monocytogenes under cold and osmotic stress conditions. Applied and Environmental Microbiology, v. 75, n. 6, p. 
1621-1627, 2009. Disponível em: <http://aem.asm.org/content/75/6/1621.full>. Acesso em 10 jan. 2013.

SCROLLAVEZZA, P.; FERRARI, F.; MARTINI, F. M. et al. Ozone treatment and blood lactate variation after thoroughbred racehorses. In: WORLD EQUINE VETERINARY ASSOCIATION MONDIAL CONGRESS, Padova. Proceedings, p. 466, 1997.

SELMA, M.V.; IBANEZA, A. M.; ALLENDE, A.; CANTWELLA, M.; SUSLOW, T. Effect of gaseous ozone and hot water on microbial and sensory quality of cantaloupe and potential transference of Escherichia coli O157:H7 during cutting. Food Microbiology, v. 25, n.1, p.162-168, 2008.

SERRA, R. et al. Use of ozone to reduce molds in a cheese ripening room. Journal of Food Protection, v. 66, n. 12, 2355-2358, 2003.

SETTANNI, L.; MOSCHETTI, G. Non-starter lactic acid bacteria used to improve cheese quality and provide health benefits. Food Microbiology, v. 27, n.6, p. 691-697, 2010.

SEYMOUR, I. J.; BURFOOT, D.; SMITH, R. L.; COX, L. A.; LOCKWOOD, A. Ultrasound decontamination of minimally processed fruits and vegetables. International Journal of Food science and Technology, v. 37, n.1, p. 547-557, 2002.

SHARMA, R. R.; DEMIRCI, A. Application of ozone for inactivation of Escherichia coli O157:H7 on inoculated alfalfa sprouts. Journal of Food Processing and Preservation, Malden, v.27, n.1, p. 51-64, 2003.

SHEELAMARY, M.; MUTHUKUMAR, M. Effectiveness of Ozone in Inactivating Listeria monocytogenes from Milk Samples. World Journal Young Researchers, v. 1, n. 3, 40, 2011.

SHEN, C; LUO, Y.; NAN, X.; BAUCHAN, G.; ZHOU, B.; WANG, Q.; MILNER, P. Enhanced inactivation of Salmonella and Pseudonomas biofilms on stainless steel by use of T-128, a fresh produce washing aid in chlorinated wash solution. Applied Environmental Microbiology, v. 78, n. 19, p. 6789-98, 2012.

SIAMANSOURI, M.; MOZAFFARI, S.; ALIKHANI, F. E. (2013). Bacteriocins and lactic acid bacteria. Journal of Biology, v. 2, n. 5, p. 227-234.

SILVA, P. H. C. Leite produzido e beneficiado no Distrito Federal e região entorno: adequação às normas estabelecidas pela Instrução Normativa $n^{\circ}$ 51. (Dissertação) Mestrado - Faculdade de Agronomia e Medicina Veterinária, Universidade de Brasília, Brasília, p. 80, 2010.

SILVA, R. M. Caracterização fenotípica e genotípica de Escherichia coli proveniente de lesões de celulite de frangos de corte. Dissertação (mestrado) - Departamento de 
Medicina Veterinária, Universidade Federal do Reconcavo Baiano, Cruz das Almas, p. 50, março de 2011.

SILVA, B.; LUVIELMO, S. M.; CURTINOVI, G. M.; IVANA, P. Potencialidades do uso do ozônio no processamento de alimentos. Semina: Ciências Agrárias, v. 32, n. 2, abriljunio, 2011, p. 659-682. Universidade Estadual de Londrina, Londrina, Brasil.

SILVA, V. A. M. et al. Avaliação da qualidade físico-química e microbiológica do leite cru, do leite pasteurizado tipo A e de pontos de contaminação de uma granja leiteira. Acta Scientiae Veterinariae, n. 38, v.1, p. 51-57, 2010.

SILVEIRA, I. C. T. Cloro e ozônio aplicados à desinfecção de efluente hospitalar tratado em contadores biológicos rotatórios, com avaliação de efeitos tóxicos em DAPHNIA SIMILIS. (Dissertação) - Doutorado em Recursos Hídricos e Saneamento Ambiental - Universidade do Rio Grande do Sul, Porto Alegre, p. 173, 2004.

SILVEIRA, N. F. A.; SILVA, N.; CONTRERAS, C.; MIYAGUSKU, L.; BACCIN, M. L. F.; KOONO, E.; BERAQUET, N. Occurrence of Escherichia coli O157:H7 in hamburgers produced in Brasil. Journal of Food Protection, v.62, n. 11, p.1333-1335, 1999.

SILVÉRIO, K.; PIERETTI, G.; ANTIGO, J.; TONON, L.; MIKCHA, J.; MADRONA, G. INCIDÊNCIA DE Listeria monocytogenes EM ALIMENTOS. Blucher Chemical Engineering Proceedings, v. 1, n. 2, p. 3156-3162, 2015.

SIMÕES, M.; SIMÕES, L. C.; E VIEIRA, M. J. A review of current and emergent biofilm control strategies. LWT-Food Science and Technology, v. 43, n. 4, p. 573-583, 2010.

SIQUEIRA, R. S.; DODD, C. E. R.; REES, C. E. D. Phage amplification assay as rapid method for Salmonelladetection. Brazilian Journal of Microbiology, v. 34 (Suppl. 1), p. 118-120, 2003.

SIQUEIRA, V. S. Regulação da Respiração e da eficiência do crescimento bacteriano em Lagoas Costeiras Tropicias. (Dissertação) Mestrado - Universidade Federal do Rio de janeiro, 2011.

SLONGO, A. P. Uso de alta pressão hidrostática em presunto fatiado: avaliação físicoquímica e sensorial e modelagem do crescimento microbiano. 2008. 143 f. Tese (Doutorado) - Engenharia de Alimentos - Universidade Federal de Santa Catarina, p. 143, Florianópolis, 2008.

SOUZA, J. B. Avaliação de métodos para desinfecção de água, empregando cloro, ácido peracético, ozônio e o processo de desinfecção combinado ozônio/cloro. 2006. (Tese) Doutorado em Hidráulica e Saneamento - Universidade de São Paulo, p.190, São Carlos. 
STEA, E. C.; PURDUE, L. M.; JAMIESON, R. C.; YOST, C. K.; TRUELSTRUP HANSEN, L. Comparasion of the prevalences and diversities of Listeria species and Listeria monocytogenes in an urban and a rural agricultural watershed. Applied and Environmental Microbiology, v. 81, n. 11, p. 3812- 3822, 2015.

STILES, M. E.; HOLZAPFEL, W. H. Lactic acid bacteria of foods and their current taxonomy. International journal of food microbiology, v. 36, n. 1, p. 1-29, 1997.

STUMER, E. S., CASASOLA, S. GALL, M. C., GALL, M. A importância dos probioticos na microbiota intestinal humana. Revista Brasileira de Nutrição Clínica. v. 27, n. 4, p. 264-72. 2012.

TIWARI, B. K.; MUTHUKUMARAPPAN, K.; O'DONNELL, C. P.; CULLEN, P. J.; Inactivation kinetics of pectin methylesterase and cloud retention in sonicated orange juice. Innovative Food Science \& Emerging Technologies, v. 10, n. 2, p. 166-171, 2009.

Ozone in fruit and vegetable processing. In: O'DONNELL, C. P., et al. Ozone in Food Processing, $1^{\mathrm{a}}$ ed., Blackwell Publishing, 2012.

TONG, S. Y.; DAVIS, J. S.; EICHENBERGER, E.; HOLLAND, T. L.; FOWLER, V. G. Staphylococcus aureus infections: epidemiology, pathophysiology, clinical manifestations, and management. Clinical microbiology reviews, v. 28, n. 3, p. 603-661, 2015.

TORNUK, F.; CANKURT, H.; OZTURK, I.; SAGDIC, O.; BAYRAM O.; YETIM, H. Efficacy of various plant hydrosols as natural food sanitizers in reducing Escherichia coli O157:H7 and Salmonella Typhimurium on fresh cut carrots and apples. International Journal of Food Microbiology, v. 148, n.1, p. 30-35, 2011.

TRABULSI, L.R. e cols. Microbiologia. $8^{\mathrm{a}}$ ed. Rio de Janeiro: Atheneu, 2008.

TREVISAN, Ana Paula. Influência de diferentes concentrações de enzima lactase e temperatura sobre a hidrólise de lactose em leite pasteurizado. (Dissertação) Mestrado Universidade Federal de Santa Maria, RS, p. 60, 2008.

TROIS, L. Uso de probióticos em crianças HIV positivas: um ensaio clínico randomizado duplo cego (controlado). (Dissertação) Mestrado - Universidade Federal do Rio Grande do Sul; RS, p. 111, 2005.

TYÖPPÖNEN, S.; PETÄJÄ, E.; MATTILA-SANDHOLM, T. Bioprotectives and probiotics for dry sausages. International Journal of Food Microbiology, v. 83, p. 233-244, 2003. USEPA - United States Environmental Protection Agency. Alternative disinfectants and oxidants guidance manual, 1999.

Disponível em: 
<http://www.epa.gov/OGWDW/mdbp/alternative_disinfectants_guidance.pdf>. Acesso em: 10 de outubro de 2015.

VALADARES FILHO, S. D. C.; PINA, D. S. Fermentação ruminal. Jaboticabal. 2. ed. Jaboticabal: Funep, p. 565-591, 2011.

VANDEKIDEREN, I.; CAMP, J.V.; DEVLIEGHERE, F.; VERAME, K.; DENON, Q.; RAGAERT, P.; DE MEULENAER, B. Effectof decontamination agents on the microbial population, sensorial quality, and nutrient content of grated carrots (Daucus carota L.). Journal of Agricultural and Food Chemistry, v. 56, n. 14, p. 5723-5731, 2008.

VASILJEVIC, T.; SHAH, N. P. Probiotics-from Metchnikoff to bioactives. International Dairy Journal, v. 18, n. 7, p. 714-728, 2008.

VÁSQUEZ-BOLAND, J.A. et al. Listeria pahogenesis and molecular virulence determinants. Clinical Microbiology Reviews, v. 14, n. 3, p. 584-640, 2001. Disponível em: <http://cmr.asm.org/content/14/3/584.full.pdf+html>. Acesso em 30 ago. 2014. doi: 10.1128/CMR.14.3.584-640.2001.

VEIGA, S. M. O. M. Sanificação de carcaças de frango: processos alternativos. (Tese) Doutorado em Ciência de Alimentos - Universidade Federal de Lavras, Lavras, p. 291, 2003.

VIDAL, F. J. R. Processo de potabilización del agua e influencia del tratamiento de ozonización. Madrid: Ediciones Díaz de Santos, 253 p, 2003.

VISVALINGAM, J.; HOLLEY, R. A. Adherenceof cold-adapted Eschecrichia coli O157:H7 to stainless steel and glass surfaces. Food Control, Guildford, v. 30, n. 2, p. 575-579, 2013.

WALSTRA, P.; WOUTERS, J. T. M.; GEURTS, T. J. Dairy science and technology. New York: CRC, p. 166 - 167. 2006.

WATERS, C.M.; and BASSLER, B. L. Quorum-sensing: cell-to-cell communication in bacteria. Annual Review of Cell and Developmental Biology, Palo Alto, v. 21, p. 31946, 2005.

WU, J.; DOAN, H.; CUENCA, M.A. Investigation of gaseous ozone as an anti-fungal fumigant for stored wheat. Journal of Chemical Technology \& Biotechnology, Oxford, v. 81, n. 7, p.1288-1293, 2006.

ZARDEN, C. F. O.; MARASSI, C. D.; FIGUEIREDO, E. E. E. S.; Lilenbaum, W. Mycobacterium bovis detection from milk of negative skin test cows. Veterinary Record, vetrec, 2013. 
ZHU, L.; FENG, X.; ZHANG, L.; ZHU, R.; LUO, X. Prevalence and Serotype of Listeria monocytogenes contamination in chinese beef processing plants. Foodborne Pathogens and Disease, v.9, n.6, p.556-560 2012. Disponível em: <http://online.liebertpub.com/doi/pdfplus/10.1089/fpd.2011.1088>. Acesso em: 24 jan. 2015.

ZOCCHE, F. et al. Qualidade microbiológica e físico-química do leite pasteurizado produzido na região oeste do Paraná. Archives of Veterinary Science, v. 7, n. 2, p. 59-67, 2002. 


\section{CAPÍtULO II}

AÇÃO DO OZÔNIO SOBRE ESCHERICHIA COLI E LACTOBACILLUS SAKEI E INTERFERÊNCIA DA MATÉRIA ORGANICA 


\title{
AÇÃO DO OZÔNIO SOBRE ESCHERICHIA COLI E LACTOBACILLUS SAKEI E INTERFERÊNCIA DA MATÉRIA ORGANICA
}

\begin{abstract}
RESUMO
O ozônio tem sido utilizado na indústria de alimentos por sua ação no controle de microrganismos indesejáveis através de seu elevado potencial oxidativo tornando-o um importante agente antimicrobiano. São escassos os dados sobre a ação do ozônio sobre microrganismos benéficos como as bactérias ácido láticas e a interferência de matéria orgânica na sua ação sanitizante. Essa pesquisa objetivou avaliar a ação do ozônio sobre o desenvolvimento de Escherichia coli (ATCC® 11229тМ) e Lactobacillus sakei subsp. sakei (ATCC ${ }^{\circledR} 15524^{\mathrm{TM}}$ ) com e sem associação de substratos orgânicos. Como substratos orgânicos foram utilizados leites de vaca com diferentes composições: integral homogeneizado com lactose, integral homogeneizado sem lactose, desnatado homogeneizado com lactose, desnatado homogeneizado sem lactose e integral sem homogeneização; também, avaliou-se a água como o substrato parâmetro de comparação. $O$ gás ozônio foi utilizado nas concentrações de 21 e $31 \mathrm{mg} / \mathrm{L}$ por $0,5,15$ e $25 \mathrm{~min}$. Para as contagens de E. coli foi utilizado o sistema Petrifilm ${ }^{\mathrm{TM}}$ EC e, para Lb. sakei o meio De Man Rogosa Sharpe. Adotouse delineamento inteiramente casualizado, em esquema em fatorial $2 \times 6 \times 4$, sendo duas concentrações, seis substratos e quatro períodos de exposição ao gás com três repetições. Os resultados obtidos demonstraram para ambas as espécies avaliadas que a composição dos substratos orgânicos interfere na ação do ozônio. As maiores reduções foram obtidas quando se utilizaram água e leite desnatado homogeneizado sem lactose. Observou-se que a E. coli é mais sensível a ação do ozônio em substratos orgânicos que Lb. sakei. Quando se avaliou a ação do ozônio sobre E. coli no substrato orgânico leite desnatado homogeneizado com lactose, independentemente do tempo, as reduções na contagem foram de 1,16 e 2,22 ciclos $\log$, para concentrações do ozônio equivalentes a 21 e $31 \mathrm{mg} / \mathrm{L}$, respectivamente. Por outro lado, para $L b$. sakei a máxima redução na contagem permaneceu em torno de 0,3 ciclo log, quando se ozonizou o substrato leite desnatado homogeneizado com lactose. Destaca-se que em água, obteve-se a máxima redução possível, levando-se em consideração o inóculo inicial e a técnica de quantificação adotada. Os resultados permitem concluir que substratos orgânicos, como os principais componentes do leite, interferem na ação do ozônio sobre $E$. coli diminuindo a sua eficácia como sanitizante e reforçando a necessidade de remoção adequada de matéria orgânica nos processos de limpeza, porém independentemente da presença desses substratos, o ozônio não altera significativamente, o desenvolvimento de bactérias ácido láticas. E por fim, a aplicação de ozônio, nas concentrações avaliadas, não produz alterações na composição do leite de vaca.
\end{abstract}

Palavras-chave: ozonização, leite, bactérias ácido láticas, sanitização de equipamentos. 


\title{
ORGANIC MATTER INTERFERENCE IN THE OZONE'S ACTION ON ESCHERICHIA COLI AND LACTOBACILLUS SAKEI
}

\begin{abstract}
The ozone has been used in the food industry due to its controlling action upon undesirable microorganisms. Its great oxidative potential makes it an important antimicrobial agent. There are a few data reporting the ozone's action upon benefic microorganisms such as lactic acid bacteria and the organic matter interference upon the ozone's sanitizing action. This research aimed to evaluate the ozone's action upon Escherichia coli (ATCC $\AA$ 11229 ${ }^{\mathrm{TM}}$ ) and Lactobacillus sakei subsp. sakei (ATCC ${ }^{\circ} 15524^{\mathrm{TM}}$ ), combined or not with organic matter. As organic matter, cow milks with different compositions were used, such as: lactose homogenized whole milk, lactose-free homogenized whole milk, lactose homogenized skimmed milk, lactose-free homogenized skimmed milk and non-homogenized whole milk; also, water added with organic matter was used as a comparative measure. The ozone gas was used under concentrations of 21 and $31 \mathrm{mg} / \mathrm{L}$, for $0,5,15$ and $25 \mathrm{~min}$. For E. coli countings, the Petrifilm ${ }^{\mathrm{TM}}$ EC was used and for the $L b$. sakei, the De Man Rogossa Sharpe was used. A Completely Randomized Design, with a $2 \times 6 \times 4$ fatorial pattern, under two concentrations, six substrates and four exposure periods of gas, with three repetitions. The results obtained shown for both evaluated species that the composition of the organic substrates interferes in the ozone action. The greatest reductions were obtained when lactose-free water and homogenized skim milk were used. It was observed that $E$. coli is more sensitive to the action of ozone on organic substrates than Lb. Sakei When evaluating the action of ozone on E. coli on organic substrate skim milk homogenized with lactose, regardless of the time, the reductions in the count were 1.16 and $2.22 \mathrm{log}$ cycles, for ozone concentrations equivalent to 21 and $31 \mathrm{mg} / \mathrm{L}$, respectively. On the other hand, for Lb. Sakei the maximum reduction in count remained around $0.3 \log$ cycle, when the substrate was skimmed milk homogenized with lactose. It is highlighted that in water, the maximum possible reduction was obtained, taking into account the initial inoculum and the technique of quantification adopted. The results allow to conclude that organic substrates, such as the main components of the milk, interfere in the action of ozone on E. coli, reducing its effectiveness as a sanitizer and reinforcing the need for adequate organic matter removal in the cleaning processes, however regardless of the presence of these Substrates, ozone does not significantly alter the development of lactic acid bacteria. Finally, the application of ozone in the evaluated concentrations does not produce changes in the composition of cow's milk.
\end{abstract}

Key words: ozonization, milk, lactic acid bacteria, equipment sanitation. 


\section{INTRODUÇÃO}

Entre os microrganismos causadores de doenças de origem alimentar, destacase E. coli, responsável por surtos alimentares (ASAO, 2003; SCHIMD, 2009; SCALLAN et al., 2011; SECRETARIA DE VIGILÂNCIA EM SAÚDE, 2011; EUROPEAN CENTRE FOR DISEASE PREVENTION AND CONTROL, 2011). Esse microrganismo é de interesse em sanidade animal e saúde pública visto que pode causar doenças tanto em animais quanto em seres humanos. Diversas pesquisas descrevem a presença desses agentes em alimentos de origem animal e vegetal, como produtos cárneos, lácteos, frutas e grãos no país e no mundo (FEITOSA et al., 2003; SANTANAM et al., 2006; TSEGMED et al., 2007; NEDER et al., 2011; OLIVEIRA et al., 2012; CALIL, 2014).

Pertencente à família Enterobacteriaceae, o gênero Escherichia compreende as espécies E. coli, E. blattae, E. fergusonii, E. hermanii, E. vulneris. No entanto, a principal espécie de importância é E. coli (CAMPOS e TRABULSI, 2002). É um bastonete curto, Gram negativo, não esporulado, medindo entre 1,1 a $1,5 \mu \mathrm{m}$ por 2 a $6 \mu \mathrm{m}$, a maioria é móvel, devido a existência de flagelos peritríqueos. A temperatura ótima de crescimento é por volta dos $37^{\circ} \mathrm{C}$ (BARNES et al., 2003; OLIVEIRA et al., 2004; QUINN et al., 2005). E. coli faz parte do grupo de coliformes fecais (coliformes a $45^{\circ} \mathrm{C}$ ) sendo considerada o mais específico indicador de contaminação fecal e eventual presença de bactérias patogênicas (OLIVEIRA et al., 2004). Vários fatores contribuem para sua disseminação no meio ambiente, pois é excretada nas fezes podendo sobreviver nas partículas fecais, poeira e água por semanas ou meses, porém seu ambiente normal é o trato intestinal (ANDRADE, 2005; SAVIOLLI, 2010).

Os isolados de E. coli, tanto de animais quanto de humanos, foram associados à patogenicidade ou mecanismo de virulência específico, que podem ser componentes do próprio microrganismo ou genes adquiridos por plasmídios, por meio dos quais as bactérias foram classificadas em patótipos. Estes patótipos podem ser classificados de acordo com suas características de virulência em EPEC (E. coli enteropatogênica), ETEC (E. coli enterotoxigênica), EIEC (E. coli enteroinvasora), EHEC (E. coli enterohemorágica), EaggEC 
(E. coli enteroagregativa), UPEC (E. coli uropatogênica), NMEC (E. coli meningite neo natal), REDEC (E. coli enteropatogênica) e APEC (E. coli patogênica aviária) (CROXEN e FINLAY, 2010; SAVIOLLI, 2010).

Bactérias ácido-láticas (BAL) são um grupo de microrganismos Gram positivos, catalase negativos, não formadores de esporos e que geralmente crescem sob condições microaerófilas ou estritamente anaeróbicas (AXELSSON, 2004; KONDYLI et al., 2012).

Os mais importantes gêneros são Lactobacillus, Lactococcus, Enterococcus, Streptococcus, Pediococcus, Leuconostoc, Weissela, Carnobacterium, Tetragenococcus e Bifidobacterium. O modo de fermentação em combinação com características fisiológicas, faixas de temperatura para o crescimento e utilização de açúcar foram utilizados como critérios de classificação para alocar gêneros e espécies de BAL (LIU et al., 2014). São classificadas devido à sua capacidade de fermentação da lactose através de seu metabolismo homo ou heterofermentativo, sendo amplamente utilizados como culturas iniciadoras em alimentos fermentados (AXELSSON, 2004). BAL homofermentativas produzem apenas ácido lático, como produto final, enquanto as heterofermentativas produzem, além de ácido lático, substâncias como dióxido de carbono, ácido acético, etanol, aldeído e diacetil (BRUNO e CARVALHO, 2009).

Além disso, essas bactérias são conhecidas pela produção de várias substâncias antimicrobianas, potencialmente utilizadas como agentes de conservação de alimentos, geradores de aromas e formação da textura nos produtos lácteos fermentados (DELAVENNE et al., 2012; WIDYASTUTI et al., 2014).

O gênero Lactobacillus spp. está amplamente distribuído no meio ambiente, especialmente em alimentos vegetais, no trato gastrintestinal e genital. A sua ocorrência é influenciada por diversos fatores ambientais, tais como $\mathrm{pH}$, presença de oxigênio, presença de fatores específicos e interações com outras bactérias (HOLT e KRIEG, 1994; GILLILAND et al., 2002). São bactérias Gram positivas, não formadores de esporos, não flagelados, geralmente anaeróbicos facultativos. São estritamente fermentativos, acumulando ácido lático no meio como produto do metabolismo primário e raramente, apresentam patogenicidade. $\mathrm{O}$ seu pH ótimo de crescimento situa-se na faixa de 5,5 e 6,3 e possuem faixa ótima de temperatura entre $30-40^{\circ} \mathrm{C}$ (HOLT e KRIEG, 1994; GOMES e MALCATA, 1999).

Lactobacillus sakei é capaz de produzir uma bacteriocina denominada sakacin $P$ que inibe o crescimento de diversas bactérias patogênicas e deteriorantes presentes em produtos cárneos e pescado, sendo amplamente utilizado na fermentação desses produtos, apresentando importante potencial tecnológico. Lb. sakei resiste às condições adversas dos 
processos de fermentação, tais como a concentração elevada do sal, a baixa atividade da água, a baixa temperatura e o pH (MCLEOD et al., 2010).

A busca de novas técnicas ou substâncias que sejam eficientes na conservação de alimentos, que apresentem baixa toxicidade e que mantenham as características de cor, textura, sabor e aroma o mais próximo ao natural do produto, ainda é um desafio para os países desenvolvidos e em desenvolvimento, apesar dos avanços na ciência e na tecnologia, Nesse sentido, as indústrias alimentícias utilizam técnicas de biopreservação e incentivam pesquisas na busca de alternativas de tratamentos sanitizantes aplicados aos alimentos, que apresentem características bioconservadoras, de forma a atender às exigências do mercado (FRANCO et al., 2008)

Os tratamentos aplicados aos alimentos devem garantir a permanência de microrganismos benéficos e eliminar os patogênicos e deteriorantes do produto final, além de preservar suas qualidades nutricionais. O processo de sanitização dos alimentos e plantas de processamento constitui uma etapa crucial na eliminação ou redução dos contaminantes microbiológicos presentes e, de certa maneira, contribuem para extensão do período de validade dos produtos (FRANCO et al., 2008; TRONCO, 2010; SCHITTLER, 2012).

A utilização de produtos a base de cloro é a mais frequente em decorrência do amplo espectro de ação. Contudo, é comprovadamente verificado que produtos clorados, sob condições de $\mathrm{pH}$, temperatura e de alguns tipos de ácidos resultantes da decomposição de matéria orgânica podem formar substâncias tóxicas indesejáveis como os organoclorados, tricloro metanos e ácidos cloro acéticos (RICO et al., 2007; ÖLMEZ e KRETZSCHMAR, 2009). Além disso, há a desvantagem de poder alterar o sabor pela presença de resíduos no alimento (MAISTRO, 2001; OLIVEIRA e VALLE, 2000).

A utilização de outros produtos em substituição ao cloro e seus derivados, que confiram segurança e qualidade microbiológica é pertinente. Diversos estudos têm comprovado a eficácia de agentes sanitizantes em substituição ao cloro, como ultrassom, ácidos orgânicos, ozônio, peróxido de hidrogênio irradiação, entre outros (GONZÁLEZAGUILAR et al., 2010; PRESTES, 2007; HOLTZ, 2006).

O ozônio tem sido utilizado em indústrias alimentícias para limpeza de superfícies e no tratamento de alimentos, a partir de sua validação como um químico Generally Recognized as Safe (GRAS) pela Food and Drug Administration (FDA). Este gás tem se mostrado um eficiente bactericida por apresentar alto poder de oxidação $(2,07 \mathrm{mV})$, sendo menor somente, que o flúor $(3,06 \mathrm{mV})$. Resultados relevantes foram encontrados na aplicação do ozônio em frutas, sucos, grãos em geral, carne e derivados, pescado e derivados 
e vegetais. Porém apesar de sua forte ação oxidante, a eficácia do processo de ozonização pode ser influenciada por diversos fatores como $\mathrm{pH}$, temperatura e composição da matéria orgânica (KELLS et al., 2001; CASTILLO, 2003; TIWARI e MUTHUKUMARAPPAN, 2012; LULLIEN-PELLERIN, 2012; POHLMAN, 2012).

O ozônio é empregado como tecnologia moderna, reconhecida por ser eficaz na redução ou mesmo eliminação de microrganismos patogênicos, além de melhorar as condições de processamento de muitos produtos, atendendo às novas tendências de mercado. Contudo, há a necessidade de estudo sobre a influência dos substratos na ação sanitizante do gás e melhores padronizações e quantificação de níveis seguros de aplicação (COELHO et al., 2015). Apesar de sua eficácia comprovada sobre microrganismos patogênicos, há uma carência de pesquisas que demonstrem sua ação sobre microrganismos benéficos, incluindo os probióticos, como os lactobacilos. Pesquisas sobre a melhor dosagem e tempo de aplicação do gás devem ser realizadas, pois agentes sanitizantes podem afetar aspectos sensoriais e nutritivos de maneira indesejável (ARTÉS et al., 2009).

Da mesma forma, é fundamental a realização de estudos que busquem elucidar a influência da composição do meio no que se refere à presença de matéria orgânica, sobre a ação e efeitos do gás, para que seja possível estabelecer condições mais efetivas e seguras da sua aplicação. O leite é uma combinação complexa de diversos elementos sólidos em água, que representam, aproximadamente, 12 a $13 \%$ do leite e a água, aproximadamente, $87 \%$. Os principais elementos sólidos do leite são lipídios (gordura), carboidratos, proteínas, sais minerais e vitaminas, representando um substrato orgânico interessante devido à possibilidade de alteração desses componentes.

O objetivo do trabalho foi avaliar a ação do ozônio sobre o desenvolvimento de E. coli e L. sakei utilizando o leite com diferentes composições como substrato orgânico, a fim de verificar a sua eficiência como sanitizante, a sua ação sobre microrganismos com potencial tecnológico na produção de alimentos e, os efeitos sobre os principais componentes do leite. 


\section{MATERIAIS E MÉTODOS}

\subsection{Local da pesquisa, origem das cepas e tratamento dos substratos}

O trabalho foi realizado nos Laboratórios de Análises de Leite e Derivados e de Pré-Processamento e Armazenamento de Produtos Agrícolas, localizados na Faculdade de Agronomia e Medicina Veterinária, da Universidade de Brasília.

Foram utilizadas as cepas Escherichia coli (ATCC® 11229 ${ }^{\mathrm{TM}}$ ) e Lactobacillu sakei subsp. sakei (ATCC® $15521^{\mathrm{TM}}$ ) cedidas pelo Laboratório de Inspeção de Produtos de Origem Animal, da Universidade Federal de Viçosa, MG, e que foram mantidas em Ágar Tripticase de Soja, enriquecido com Extrato de Levedura (TSA-YE) (Kasvi®). Antes de cada inoculação, foram recuperadas em Caldo Tripticase de Soja (TSB) $\left(\right.$ Bacto $^{\mathrm{TM}}$ ) e semeadas em TSA-YE em superfície incubadas a $35^{\circ} \mathrm{C}$ por 24 horas.

Como substratos orgânicos foram utilizados: Leite Integral Não Homogeneizado (LINH); Leite Integral Homogeneizado (LIH); Leite Desnatado (LD); Leite Desnatado Zero Lactose (LDZL); Leite Integral Zero Lactose (LIZL), obtidos de estabelecimentos comerciais. De acordo com a Instrução Normativa 62/2011 (BRASIL, 2011), a classificação do leite, em relação ao teor de gordura é: integral $(\geq 3,0 \%)$; semidesnatado $(2,9 \%$ a $0,6 \%)$ e desnatado $(\leq 0,5 \%)$. Os leites foram esterilizados laboratorialmente por fervura, como forma de garantir a eliminação de qualquer outro microrganismo e resfriados antes das inoculações. Todos os procedimentos também foram conduzidos em água destilada utilizada como parâmetro de comparação.

\subsection{Preparo dos inóculos}

Colônias desenvolvidas no TSA-YE foram inoculadas em solução salina $0,85 \%$ de forma a obter-se grau de turvação correspondente ao tubo 1 da escala nefelométrica de McFarland (Nefelobac $®$, Probac do Brasil), contendo aproximadamente 3,0 x $10^{8} \mathrm{UFC} / \mathrm{mL}$ (inóculo mãe). A partir desse inóculo, $9,0 \mathrm{~mL}$ eram transferidos para balão volumétrico 
contendo $91 \mathrm{~mL}$ de cada substrato, como forma de se obter contagens aproximadas de $10^{6}$ UFC/mL; após, 3,0 mL eram inoculados em $297 \mathrm{~mL}$ do substrato obtendo-se contagens correspondentes a cerca de $10^{4} \mathrm{UFC} / \mathrm{mL}$.

\subsection{Aplicação do ozônio}

O gás ozônio foi obtido por meio de um gerador de ozônio (Modelo O\&L 3.0O2 RM, da Ozone \& Life®) baseado no método de Descarga por Barreira Dielétrica que é produzido ao aplicar uma alta tensão entre dois eletrodos paralelos, tendo entre eles um dielétrico (vidro) e um espaço livre por onde flui o ar seco. Neste espaço é produzida uma descarga em forma de filamentos, que gera elétrons com energia suficiente para produzir a quebra das moléculas de oxigênio $\left(\mathrm{O}_{2}\right)$, formando o ozônio $\left(\mathrm{O}_{3}\right)$. $\mathrm{O}$ insumo de oxigênio é obtido por concentrador de oxigênio acoplado ao gerador de ozônio.

A concentração de ozônio foi determinada pelo método iodométrico, descrito por Clesceri et al. (2000) e Couto et al., 2016, onde o borbulhamento de massa gasosa contendo ozônio em $50 \mathrm{~mL}$ de solução de iodeto de potássio $(\mathrm{KI}) 1 \mathrm{~N}$, produz iodo $\left(\mathrm{I}_{2}\right)$. Para isso é necessário acidificar o meio com $2,5 \mathrm{~mL}$ de ácido sulfúrico $\left(\mathrm{H}_{2} \mathrm{SO}_{4}\right) 1 \mathrm{~N}$, depois do borbulhamento. A solução foi titulada com tiossulfato de sódio $\left(\mathrm{Na}_{2} \mathrm{~S}_{2} \mathrm{O}_{3}\right)$ 0,01 N, com uso de solução de amido $1 \%$ como indicador.

Cada amostra de substrato foi transferida para uma coluna de vidro, com capacidade de $500 \mathrm{~mL}$, tendo $19 \mathrm{~cm}$ de altura e $6,0 \mathrm{~cm}$ de diâmetro. Antes da ozonização de cada amostra, a coluna de vidro foi sanitizada, com borbulhamento do próprio gás ozônio em água, por cinco minutos. Foi instalado o destruidor térmico catalítico depois da coluna de ozonização, necessária para decomposição do ozônio residual.

\subsection{Binômios concentração de ozônio $x$ tempo de exposição}

A partir de resultados obtidos em estudos anteriores desenvolvidos pelo grupo de pesquisa dos laboratórios envolvidos (SANTOS, 2013; COUTO et al., 2016) e por Sheelamary e Muthukumar, 2011, foram aplicadas as concentrações de $21 \mathrm{mg} / \mathrm{L}$ e de 31 $\mathrm{mg} / \mathrm{L}$, nos tempos de $0,5,15$ e 25 minutos para os dois micorganismos testados. Cada tratamento foi conduzido em triplicata. 


\subsection{Contagens microbiológicas dos substratos inoculados}

As contagens de E. coli antes e após o processo de ozonização, foram realizadas por meio de semeaduras em sistema Petrifilm ${ }^{\mathrm{TM}}$ EC (3M do Brasil) conforme recomendações do fabricante; para $L b$. sakei as contagens foram realizadas a partir de semeadura de 0,1 mL em meio De Man Rogosa and Sharpe (MRS) (Acumedia®), em superficie e com incubação a $35^{\circ} \mathrm{C}$ por 24 horas. Os resultados das contagens dos microrganismos testados foram convertidos em $\log _{10}$.

\subsection{Análises físico-químicas}

As amostras foram analisadas quanto aos teores de proteína, lactose, gordura, sólidos não gordurosos e por meio de equipamento ultrassônico EKOMILK realizadas conforme o fabricante (Ekomilk Total®).

\subsection{Delineamento Experimental}

Adotou-se Delineamento Inteiramente Casualizado, em esquema em fatorial 2 x 6 x 4, sendo duas concentrações (21 e $31 \mathrm{mg} / \mathrm{L}$ ), seis substratos (LINH, LIH, LD, LDZL, LIZL e água destilada) e quatro períodos de exposição ao gás $(0,5,15$ e 25 min) com três repetições. Foi realizada análise de variância a 5\% de probabilidade, utilizando-se o software ASSISTAT 7.7 BET. Realizou-se teste de média, utilizando-se o Teste de Tukey a 5\% de probabilidade ou análise de regressão. Análise de regressão foi adotada quando se avaliou o efeito do período de ozonização. Utilizou-se o software SigmaPlot na obtenção das equações de regressão e na plotagem dos gráficos. 


\section{RESULTADOS}

De acordo com a Análise de Variância, não houve variação significativa (p>0,05) na redução da contagem de E. coli em decorrência da interação tripla entre concentração do ozônio, substrato e período de exposição ao gás (Tabela 1). Entretanto, as interações entre concentração do ozônio e substrato e entre substrato e período de exposição ao gás foram significativas $(\mathrm{p}<0,01)$. Com relação à redução na contagem de $L b$. sakei, verificou-se variação significativa $(\mathrm{p}<0,01)$ devido à interação tripla entre concentração do ozônio, substrato e período de exposição ao gás.

Tabela 1. Resumo da análise de variância referente à redução nas contagens de Escherichia coli e de Lactobacillus sakei $\left(\log \mathrm{N}_{0} / \mathrm{N}\right)$ inoculadas em leite com diferentes composições ozonizados em diferentes combinações de concentração do ozônio e período de exposição ao gás.

\begin{tabular}{c|c|c|c}
\hline \multirow{2}{*}{ Fonte de variação } & \multirow{2}{*}{$\begin{array}{c}\text { Grau de } \\
\text { Liberdade }\end{array}$} & Quadrado Médio & Quadrado Médio \\
\cline { 3 - 4 } & 1 & Escherichia coli & Lactobacillus sakei \\
\hline Concentração (C) & 5 & $0,9209^{*}$ & $0,1333^{* *}$ \\
\hline Substrato (S) & 5 & $24,2078^{* *}$ & $25,2286^{* *}$ \\
\hline Período (P) & 3 & $31,2420^{* *}$ & $7,5229^{* *}$ \\
\hline C x S & 5 & $1,0045^{* *}$ & $0,0199^{\mathrm{ns}}$ \\
\hline C x P & 3 & $0,2564^{\mathrm{ns}}$ & $0,0154^{\mathrm{ns}}$ \\
\hline S x P & 15 & $3,2660^{* *}$ & $2,8527^{* *}$ \\
\hline C x S x P & 15 & $0,2374^{\mathrm{ns}}$ & $0,0284^{* *}$ \\
\hline Tratamentos & 47 & $5,8304^{* *}$ & $4,0895^{* *}$ \\
\hline Resíduo & 96 & 0,2260 & 0,0106 \\
\hline CV (\%) & & 36,55 & 15,29 \\
\hline
\end{tabular}

Legenda: ** significativo ao nível de $1 \%$ de probabilidade $(\mathrm{p}<0,01)$.

* significativo ao nível de $5 \%$ de probabilidade $(\mathrm{p}<0,05)$.

${ }^{\text {ns }}$ não significativo ao nível de $5 \%$ de probabilidade $(\mathrm{p}<0,05)$.

cv- coeficiente de variação 
Na Tabela 2 estão contidos os valores médios relativos à redução $\left(\log \mathrm{N}_{0} / \mathrm{N}\right)$ na contagem de E. coli devido à interação entre concentração do ozônio e os leites com diferentes composições, independentemente do período de exposição ao gás. Quando se analisou a variação na redução da contagem de E. coli em cada uma das concentrações do gás, os maiores valores médios $(\mathrm{p}<0,05)$ foram obtidos quando os substratos foram água destilada e LDZL, com valores médios entre 3,44 e 3,38 ciclos log e entre 3,10 e 3,36 ciclos log, respectivamente. Somente no substrato LIZL houve variação siginificativa $(\mathrm{p}<0,05)$ na contagem de E. coli com o aumento da concentração do gás, sendo equivalente a 1,16 e 2,44 ciclos log, nas concentrações do ozônio de 21 e $31 \mathrm{mg} / \mathrm{L}$, respectivamente. Ressalta-se a inexpressiva redução na contagem de $E$. coli em decorrência da ozonização nos substratos LINH e LIH. No substrato LIH, os valores médios obtidos foram inferiores a 0,4 ciclo log.

Tabela 2. Valores médios referentes à redução na contagem de Escherichia coli $\left(\log \mathrm{N}_{0} / \mathrm{N}\right)$ em leite com diferentes composições ozonizados nas concentrações de 21 e $31 \mathrm{mg} / \mathrm{L}$ independente do período de exposição ao gás

\begin{tabular}{|c|c|c|c|c|c|c|}
\hline \multirow{2}{*}{$\begin{array}{c}\mathrm{C} \\
(\mathrm{mg} / \mathrm{L})\end{array}$} & \multicolumn{6}{|c|}{ Substrato } \\
\hline & LINH & & $\mathrm{LIH}$ & $\mathrm{LD}^{\prime}$ & & IZL \\
\hline 21 & $0,37 \pm 0,22 \mathrm{aCD}$ & $0,33 \pm 0,24 \mathrm{aD}$ & $1,10 \pm 0,42 \mathrm{aBC}$ & $3,36 \pm 0,38 \mathrm{aA}$ & $1,16 \pm 1,01 \mathrm{bB}$ & $3,44 \pm 0,07 \mathrm{aA}$ \\
\hline 31 & $0,52 \pm 0,31 \mathrm{aCD}$ & $0,37 \pm 0,23 \mathrm{Ad}$ & $1,23 \pm 0,92 \mathrm{aC}$ & $3,10 \pm 0,88 \mathrm{aAB}$ & $2,44 \pm 0,77 \mathrm{aB}$ & $3,38 \pm 0,04 \mathrm{aA}$ \\
\hline
\end{tabular}

Legenda: Médias seguidas de mesma letra minúscula na coluna e de mesma letra maiúscula na linha não diferem estatisticamente pelo Teste de Tukey a 5\% de probabilidade.

LINH - Leite Integral Não Homogeneizado; LIH - Leite Integral Homogeneizado; LD - Leite Desnatado; LDZL - Leite Desnatado Zero Lactose; LIZL - Leite Integral Zero Lactose; AD - Água destilada.

Na Figura 3 são apresentadas as curvas de regressão referentes à redução na contagem de E. coli em leite com diferentes composições ozonizados, com períodos de exposição de até $25 \mathrm{mim}$, independentemente da concentração do gás. Observou-se que, à medida que se eleva o período de exposição ao ozônio, há incremento na redução da contagem de $E$. coli para todos os substratos. O incremento na redução da contagem de $E$. coli durante o período de ozonização foi mais acentuado quando se utilizaram água destilada e LDZL como substratos, atingindo-se valores superiores a 3,0 ciclos log. Por outro lado, o incremento na redução da contagem de E. coli em decorrência da ozonização foi menos acentuado nos substratos LINH e LIH, com reduções inferiores a 0,8 e 0,6 ciclo log, respectivamente, depois de 25 min de ozonização. 


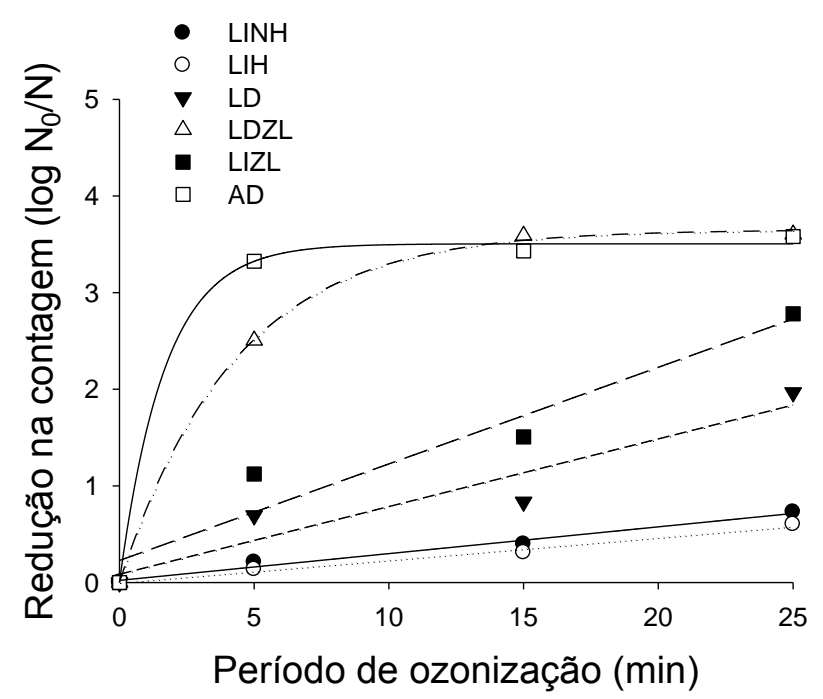

Figura 3. Redução na contagem de Escherichia coli $\left(\log \mathrm{N}_{0} / \mathrm{N}\right)$ em leite com diferentes composições em função do período de ozonização.

Legenda: LINH - Leite Integral Não Homogeneizado; LIH - Leite Integral Homogeneizado; LD Leite Desnatado; LDZL - Leite Desnatado Zero Lactose; LIZL - Leite Integral Zero Lactose; AD Água destilada.

Na Tabela 3 encontram-se as equações de regressão ajustadas para redução na contagem de E. coli em leite com diferentes composições em função do período de ozonização e seus respectivos coeficientes de determinação.

Tabela 3. Equações de regressão ajustadas em função do tempo para redução na contagem de Escherichia coli $\left(\log \mathrm{N}_{0} / \mathrm{N}\right)$ em leite com diferentes composições em função do período de ozonização e seus respectivos coeficientes de determinação (R2).

\begin{tabular}{ccc}
\hline Substrato & Equações ajustadas & $\mathrm{R}^{2}$ \\
\hline LINH & $\hat{\mathrm{y}}=0,022+0,028 \mathrm{x}$ & 0,98 \\
LIH & $\widehat{\mathrm{y}}=0,023 \mathrm{x}$ & 0,99 \\
LD & $\widehat{\mathrm{y}}=0,086+0,070 \mathrm{x}$ & 0,91 \\
LDZL & $\hat{\mathrm{y}}=3,652\left(1-e^{(-0,233 \mathrm{x})}\right)$ & 0,99 \\
LIZL & $\hat{\mathrm{y}}=0,228\left(1-e^{(-0,100 \mathrm{x})}\right)$ & 0,93 \\
AD & $\hat{\mathrm{y}}=3,505\left(1-e^{(-0,593 \mathrm{x})}\right)$ & 0,99
\end{tabular}

Legenda: LINH - Leite Integral Não Homogeneizado; LIH - Leite Integral Homogeneizado; LD Leite Desnatado; LDZL - Leite Desnatado Zero Lactose; LIZL - Leite Integral Zero Lactose; AD Água destilada.

Os valores médios relativos à redução na contagem de Lb. sakei em ciclos log, quando se avaliaram diferentes combinações de substratos e períodos de exposição ao ozônio 
em função da concentração do gás são apresentados na Tabela 4. Em geral, não houve aumento significativo $(\mathrm{p}<0,05)$ na redução da contagem de $L b$. sakei com o aumento da concentração do ozônio, exceto no substrato $\mathrm{LD}$, em períodos de exposição de 5 e 15 min, e no substrato LDZL combinado com período de ozonização de 25 min.

Tabela 4. Valores médios referentes à redução na contagem de Lactobacillus sakei (log N0/N) em diferentes combinações de substrato $(\mathrm{S})$ e período de exposição $(\mathrm{P})$ nas concentrações $(\mathrm{C})$ de ozônio de 21 e $31 \mathrm{mg} / \mathrm{L}$

\begin{tabular}{|c|c|c|c|c|c|}
\hline \multirow{2}{*}{$\mathrm{S} \times \mathrm{P}(\min )$} & \multicolumn{2}{|c|}{$\mathrm{C}(\mathrm{mg} / \mathrm{L})$} & \multirow{2}{*}{$\mathrm{S} \times \mathrm{P}(\min )$} & \multicolumn{2}{|c|}{$\mathrm{C}(\mathrm{mg} / \mathrm{L})$} \\
\hline & 21 & 31 & & 21 & 31 \\
\hline$\overline{\mathrm{LINH} / 5}$ & $0,04 \pm 0,03 a$ & $0,07 \pm 0,01 \mathrm{a}$ & LDZL/5 & $0,790,10 \pm a$ & $0,71 \pm 0,13 \mathrm{a}$ \\
\hline LINH/15 & $0,11 \pm 0,04 \mathrm{a}$ & $0,01 \pm 0,05 \mathrm{a}$ & LDZL/15 & $0,80 \pm 0,14 a$ & $0,85 \pm 0,36 \mathrm{a}$ \\
\hline LINH/25 & $0,40 \pm 0,09 \mathrm{a}$ & $0,39 \pm 0,16 \mathrm{a}$ & LDZL/25 & $1,03 \pm 0,08 b$ & $1,49 \pm 0,32 \mathrm{a}$ \\
\hline $\mathrm{LIH} / 5$ & $0,01 \pm 0,02 \mathrm{a}$ & $0,02 \pm 0,01 \mathrm{a}$ & LIZL/5 & $0,32 \pm 0,03 \mathrm{a}$ & $0,40 \pm 0,07 \mathrm{a}$ \\
\hline $\mathrm{LIH} / 15$ & $0,03 \pm 0,01 \mathrm{a}$ & $0,04 \pm 0,02 \mathrm{a}$ & LIZL/15 & $0,40 \pm 0,15 \mathrm{a}$ & $0,39 \pm 0,08 \mathrm{a}$ \\
\hline $\mathrm{LIH} / 25$ & $0,03 \pm 0,03 a$ & $0,06 \pm 0,03 \mathrm{a}$ & LIZL/25 & $0,40 \pm 0,18 \mathrm{a}$ & $0,37 \pm 0,11 \mathrm{a}$ \\
\hline $\mathrm{LD} / 5$ & $0,07 \pm 0,10 \mathrm{~b}$ & $0,29 \pm 0,09 a$ & $\mathrm{AD} / 5$ & $3,31 \pm 0,10 \mathrm{a}$ & $3,59 \pm 0,07 \mathrm{a}$ \\
\hline $\mathrm{LD} / 15$ & $0,08 \pm 0,05 b$ & $0,30 \pm 0,08 \mathrm{a}$ & $\mathrm{AD} / 15$ & $3,53 \pm 0,07 a$ & $3,79 \pm 0,08 \mathrm{a}$ \\
\hline $\mathrm{LD} / 25$ & $0,31 \pm 0,14 \mathrm{a}$ & $0,31 \pm 0,04 a$ & $\mathrm{AD} / 25$ & $3,73 \pm 0,03 \mathrm{a}$ & $3,70 \pm 0,07 \mathrm{a}$ \\
\hline
\end{tabular}

Legenda: Médias seguidas de mesma letra minúscula na linha não diferem estatisticamente pelo Teste de Tukey a $5 \%$ de probabilidade.

LINH - Leite Integral Não Homogeneizado; LIH - Leite Integral Homogeneizado; LD - Leite Desnatado; LDZL - Leite Desnatado Zero Lactose; LIZL - Leite Integral Zero Lactose; AD - Água destilada.

Na Tabela 5 podem ser observados os valores médios de reduções em ciclos log na contagem de $L b$. sakei, quando se avaliaram diferentes combinações de concentração do ozônio e períodos de exposição ao gás em leite com diferentes composições. Verificou-se diferença significativa $(\mathrm{p}<0,05)$ em todas as combinações de concentração do ozônio e período de exposição ao gás em função do substrato utilizado. As maiores reduções na contagem de $L b$. sakei foram observadas quando foram ozonizados na água e no substrato LDZL, com valores médios entre 3,32 e 3,79 ciclos log e entre 0,79 e 1,49 ciclos $\log$, respectivamente. Por outro lado, verificou-se inexpressiva redução na contagem de Lb. sakei quando utilizado o substrato LIH. Na avaliação do efeito do ozônio na contagem de Lb. sakei no substrato $\mathrm{LIH}$, os valores médios de redução permaneceram inferiores a 0,1 ciclo log, em todas as combinações de concentração do ozônio e período de exposição ao gás. 
Tabela 5. Valores médios referentes à redução na contagem de Lactobacillus sakei $\left(\log \mathrm{N}_{0} / \mathrm{N}\right)$ em diferentes combinações de concentração de gás $(\mathrm{C})$ e período de exposição $(\mathrm{P})$ em leite com diferentes composições

\begin{tabular}{c|cccccc}
\hline \multirow{2}{*}{$\begin{array}{c}\text { C } \\
(\mathrm{mg} / \mathrm{L}) \times \mathrm{P}(\mathrm{min})\end{array}$} & LINH & LIH & LD & LDZL & LIZL & AD \\
\cline { 2 - 7 } & $0,04 \pm 0,03 \mathrm{~d}$ & $0,01 \pm 0,02 \mathrm{~d}$ & $0,07 \pm 0,10 \mathrm{~d}$ & $0,79 \pm 0,10 \mathrm{~b}$ & $0,32 \pm 0,03 \mathrm{c}$ & $3,32 \pm 0,10 \mathrm{a}$ \\
$21 / 5$ & $0,11 \pm 0,04 \mathrm{~d}$ & $0,03 \pm 0,01 \mathrm{~d}$ & $0,08 \pm 0,05 \mathrm{~d}$ & $0,80 \pm 0,14 \mathrm{~b}$ & $0,40 \pm 0,15 \mathrm{c}$ & $3,53 \pm 0,07 \mathrm{a}$ \\
$21 / 15$ & $0,40 \pm 0,09 \mathrm{c}$ & $0,03 \pm 0,03 \mathrm{~d}$ & $0,31 \pm 0,14 \mathrm{c}$ & $1,03 \pm 0,08 \mathrm{~b}$ & $0,41 \pm 0,18 \mathrm{c}$ & $3,73 \pm 0,03 \mathrm{a}$ \\
$31 / 25$ & $0,07 \pm 0,01 \mathrm{de}$ & $0,02 \pm 0,01 \mathrm{e}$ & $0,29 \pm 0,09 \mathrm{~cd}$ & $0,71 \pm 0,13 \mathrm{~b}$ & $0,40 \pm 0,07 \mathrm{c}$ & $3,59 \pm 0,07 \mathrm{a}$ \\
$31 / 15$ & $0,01 \pm 0,05 \mathrm{de}$ & $0,04 \pm 0,02 \mathrm{e}$ & $0,30 \pm 0,08 \mathrm{~cd}$ & $0,85 \pm 0,36 \mathrm{~b}$ & $0,39 \pm 0,08 \mathrm{c}$ & $3,79 \pm 0,08 \mathrm{a}$ \\
$31 / 25$ & $0,39 \pm 0,16 \mathrm{c}$ & $0,06 \pm 0,03 \mathrm{~d}$ & $0,31 \pm 0,04 \mathrm{c}$ & $1,49 \pm 0,32 \mathrm{~b}$ & $0,37 \pm 0,11 \mathrm{c}$ & $3,70 \pm 0,07 \mathrm{a}$ \\
\hline
\end{tabular}

Legenda: Médias seguidas de mesma letra minúscula na linha não diferem estatisticamente pelo Teste de Tukey a $5 \%$ de probabilidade.

LINH - Leite Integral Não Homogeneizado; LIH - Leite Integral Homogeneizado; LD - Leite Desnatado; LDZL - Leite Desnatado Zero Lactose; LIZL - Leite Integral Zero Lactose; AD - Água destilada.

Na Tabela 6 estão contidas as equações de regressão ajustadas para redução na contagem de $L b$. sakei em leite com diferentes composições, nas concentrações de 21 e 31 $\mathrm{mg} / \mathrm{L}$, em função do período de ozonização e seus respectivos coeficientes de determinação. Verificou-se redução mais acentuada quando o substrato foi água. Nos substratos que continham matéria orgânica, esse comportamento foi mais acentuado no LDZL. Nesse substrato, observou-se aumento na redução da contagem de Lb. sakei com o aumento da concentração do gás. Quando se adotou concentração do ozônio de $21 \mathrm{mg} / \mathrm{L}$, obteve-se redução de aproximadamente 1,0 ciclo log, depois de 25 min de ozonização. Na concentração de $31 \mathrm{mg} / \mathrm{L}$ por período de exposição de $25 \mathrm{~min}$, a redução na contagem de $L b$. sakei foi de aproximadamente 1,5 ciclo $\log$. 
Tabela 6. Equações de regressão ajustados em função do período de ozonização ao ozônio para redução na contagem de Lactobacillus sakei $\left(\log \mathrm{N}_{0} / \mathrm{N}\right)$ em leite com diferentes composições e nas concentrações de 21 e $31 \mathrm{mg} / \mathrm{L}$ e seus respevtivos coeficientes de determinação

\begin{tabular}{|c|c|c|c|}
\hline $\begin{array}{c}\text { Concentração do } \\
\text { ozônio (mg/L) }\end{array}$ & Substrato & Equações ajustadas & $\mathbf{R}^{2}$ \\
\hline \multirow{6}{*}{21} & $\overline{\mathrm{LINH}}$ & $\widehat{\mathrm{y}}=-0,035+0,015 \mathrm{x}$ & 0,89 \\
\hline & LIH & $\widehat{y}=0,001+0,001 x$ & 0,85 \\
\hline & LD & $\widehat{y}=0,010+0,011 x$ & 0,84 \\
\hline & LDZL & $\hat{y}=0,918\left(1-e^{(-0,388 x)}\right)$ & 0,96 \\
\hline & LIZL & $\hat{\mathrm{y}}=0,407\left(1-e^{(-0,319 \mathrm{x})}\right)$ & 0,99 \\
\hline & $\mathrm{AD}$ & $\hat{y}=3,634\left(1-e^{(-0,489 x)}\right)$ & 0,99 \\
\hline \multirow{6}{*}{31} & LINH & $\widehat{\mathrm{y}}=-0,023+0,014 \mathrm{x}$ & 0,85 \\
\hline & LIH & $\widehat{\mathrm{y}}=0,001+0,002 \mathrm{x}$ & 0,95 \\
\hline & $\mathrm{LD}$ & $\widehat{\mathrm{y}}=0,302+0,648 \mathrm{x}$ & 0,99 \\
\hline & LDZL & $\hat{y}=1,723\left(1-e^{(-0,065 x)}\right)$ & 0,89 \\
\hline & LIZL & $\hat{y}=0,378\left(1-e^{(-0,555 x)}\right)$ & 0,99 \\
\hline & $\mathrm{AD}$ & $\hat{y}=3,747\left(1-e^{(-0,632 x)}\right)$ & 0,99 \\
\hline
\end{tabular}

Legenda: LINH - Leite Integral Não Homogeneizado; LIH - Leite Integral Homogeneizado; LD Leite Desnatado; LDZL - Leite Desnatado Zero Lactose; LIZL - Leite Integral Zero Lactose; AD Água destilada.

As curvas de regressão referentes à redução na contagem de Lb. sakei em decorrência da ozonização, em leite com diferentes composições e nas concentrações de 21 e $31 \mathrm{mg} / \mathrm{L}$ são apresentadas na Figura 4. 

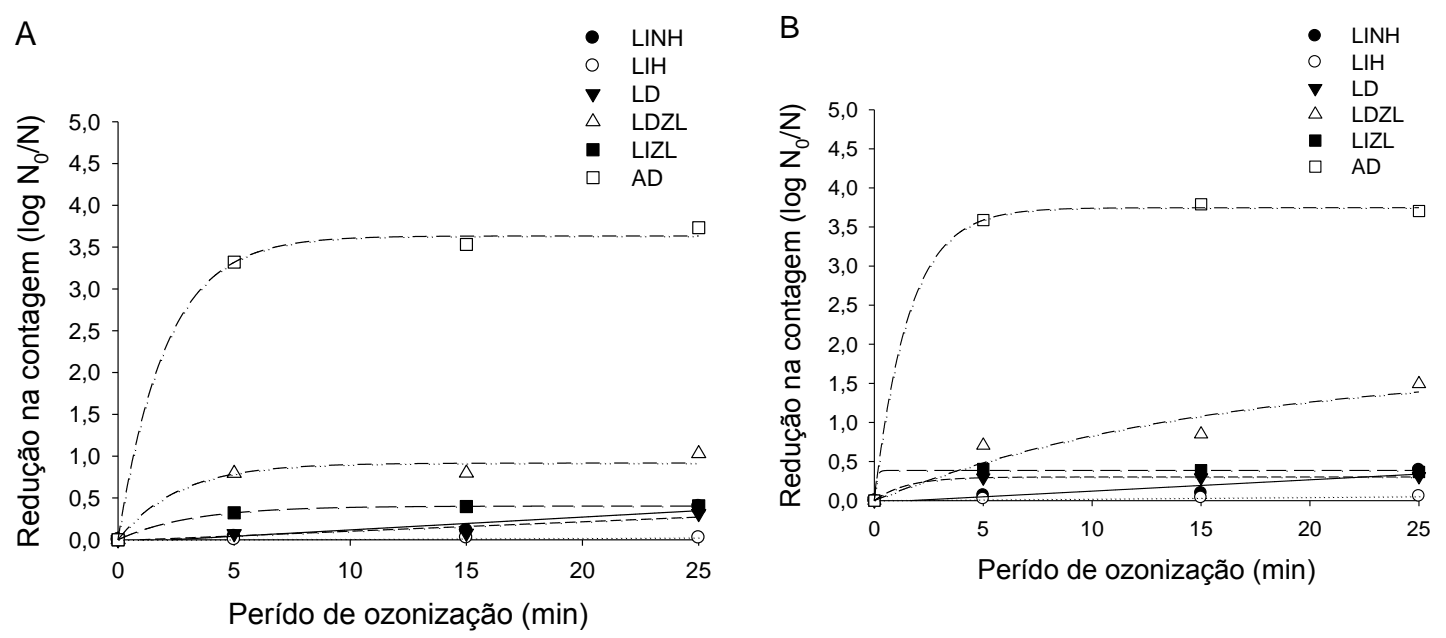

Figura 4. Redução na contagem de Lactobacillus sakei $\left(\log \mathrm{N}_{0} / \mathrm{N}\right)$ em leite com diferentes composições nas concentrações de $21 \mathrm{mg} / \mathrm{L}$ (A) e $31 \mathrm{mg} / \mathrm{L}$ ( B) em função do tempo.

Legenda: LINH - Leite Integral Não Homogeneizado; LIH - Leite Integral Homogeneizado; LD Leite Desnatado; LDZL - Leite Desnatado Zero Lactose; LIZL - Leite Integral Zero Lactose; AD Água destilada.

É importante ressaltar que, tanto para E. coli quanto para Lb. sakei, quando o substrato ozonizado foi água destilada, independentemente da concentração do ozônio, obteve-se máxima redução detectável com cinco minutos de exposição ao gás, tendo em vista o inóculo inicial e a técnica de quantificação adotada.

No que se refere ao efeito do ozônio na qualidade físico-química nos substratos orgânicos, em geral não foi verificada variação significativa ( $p>0,05)$ em decorrências das diferentes combinações de concentração do gás e período de exposição, conforme apresentado nas Tabelas 1A e 1B (Anexo A). Somente foram verificadas variações significativas $(p<0,05)$ no substrato LINH, na concentração de $31 \mathrm{mg} / \mathrm{L}$ e períodos de exposição de 15 e 25 min. Nesses binômios foram observadas reduções nos teores de lactose, de proteínas, de gordura e de sólidos não gordurosos. 


\section{DISCUSSÃO}

Os resultados obtidos demonstraram que o ozônio é capaz de reduzir a contagem de E. coli e de Lb. sakei. Entretanto, Lb. sakei se mostrou mais resistente à ação do ozônio nos substratos orgânicos do que E. coli. Além disso, verificou-se que a composição dos substratos afeta a eficácia do ozônio como agente antimicrobiano. Diversos trabalhos comprovam a eficácia do ozônio na inativação de microrganismos, tais como fungos, bactérias, vírus, além de esporos de fungos e de bactérias (NASCIMENTO et al., 2006; GUZEL-SEYDIM et al., 2004 a e b; JYOTI e PANDIT, 2003 e 2004; GEHR et al., 2003; VEIGA, 2003; VELANO et al., 2001; XU et al., 2002; RESTAINO et al., 1995). Dentre as espécies de bactérias já estudadas e que apresentaram sensibilidade ao ozônio, podem ser destacadas Bacillus subtilis, Escherichia coli, Listeria monocytogenes, Pseudomonas aeruginosa, Salmonella spp, Streptococcus faecalis e Staphylococcus aureus (RESTAINO et al., 1995; LEZCANO et al., 2000; TALBOT et al., 2012; SUNG et al., 2014).

A inativação dos microrganismos é diretamente relacionada à ação do gás sobre suas estruturas. O ozônio atua inicialmente na membrana celular, sendo a superfície da célula microbiana o primeiro alvo a ser atingido. Sua ação antimicrobiana é decorrente da oxidação de glicolipídeos, glicoproteínas e aminoácidos da parede celular, alterando a permeabilidade e causando sua rápida lise. O gás tem efeito também, sobre enzimas ocasionando o colapso da atividade enzimática celular. Além disso, sua ação sobre o material nuclear dos microrganismos altera as bases púricas e pirimídicas dos ácidos nucléicos, o que destrói o material genético das células (HUNT e MARIÑAS, 1999; SILVEIRA, 2004). A inativação dos microrganismos devido à ozonização depende da concentração de ozônio, do tempo de aplicação e do microrganismo envolvido (da SILVA et al., 2011). De acordo com PASCUAL et al. (2007), cada microrganismo apresenta sensibilidade inerente ao ozônio, de tal forma que as bactérias são mais sensíveis que fungos e leveduras; bactérias Gram negativas são mais sensíveis que as Gram positivas e os esporos são mais resistentes que as células vegetativas. 
A pesquisa confirmou essa maior sensibilidade de bactérias Gram negativas ao ozônio em comparação à Gram positiva, inoculadas em diferentes substratos orgânicos. $E$. coli foi significativamente mais sensível ao ozônio do que $L b$. sakei, que é uma bactéria ácido lática Gram positiva. No substrato LDZL, as reduções nas contagens de E. coli, independentemente do tempo, permaneceram entre 3,10 e 3,36 ciclos log, enquanto que para Lb. sakei, a maior redução foi obtida foi de 1,49 ciclos log, quando adotada a concentração de $31 \mathrm{mg} / \mathrm{L}$ e período de ozonização de 25 min. Quando se avaliou a ação do ozônio sobre $E$. coli no substrato LD, independentemente do tempo, as reduções na contagem foram de 1,16 e 2,22 ciclos log, para concentrações do ozônio equivalente a 21 e $31 \mathrm{mg} / \mathrm{L}$, respectivamente. Para $L b$. sakei a máxima redução na contagem permaneceu em torno de 0,3 ciclo log, quando se ozonizou o substrato LD. RESTAINO et al. (1995) também verificaram maior sensibilidade ao ozônio de bactérias Gram negativas em comparação com bactérias Gram positivas na presença ou não de matérias orgânica.

É possível que a maior sensibilidade das bactérias Gram negativas esteja associada à diferença na estrutura da parede celular. As bactérias Gram negativas apresentam uma parede celular formada por uma ou poucas camadas de peptideoglicano e uma membrana externa que não constitui uma barreira para todas as substâncias no ambiente, sendo mais permeável devido à presença de porinas que formam canais que, por sua vez, permitem a passagem de determinadas moléculas, sendo inclusive, mais suscetíveis ao rompimento mecânico. Já as bactérias Gram positivas apresentam parede celular constituída por várias camadas de peptideoglicano que formam uma estrutura espessa e rígida (TORTORA, 2012; JAY, 2005).

Outro fator que afetou a eficácia do ozônio no controle de E. coli e Lb. sakei foi a composição dos substratos. As maiores reduções foram obtidas em água destilada para ambas as espécies. Todavia, observou-se menor redução na contagem dos microrganismos nos substratos orgânicos. Quanto mais rica a composição do substrato, menor foi a eficácia do ozônio na redução de microrganismos. As maiores reduções nas contagens dos microrganismos nos substratos contendo matéria orgânica foram obtidas para LDZL, substrato caracterizado por possuir no máximo $0,5 \%$ de gordura e no máximo $0,5 \%$ de lactose. Não há regulamento específico para leite com baixo teor de lactose, porém segundo a legislação aplicada para esse tipo de produto, a Portaria no 29 de 1998 do Ministério da Saúde, alimentos especialmente formulados para atender portadores de intolerância à ingestão de lactose podem conter no máximo $0,5 \mathrm{~g}$ do nutriente por $100 \mathrm{~g}$ ou $100 \mathrm{~mL}$ do produto final (BRASIL, 1998). 
Por outro lado, as menores reduções foram observadas quando se utilizaram os meios LIH e LINH. Nesses substratos são esperados teores de gordura de no mínimo 3,0\% e teores de lactose em torno de 5,0\%, já que, de acordo com Longo, 2006, do ponto de vista físico-químico, a lactose está presente no leite em média 5,0\% no estado molecular em solução verdadeira, com partículas de diâmetros inferiores a $1 \mathrm{~nm}$.

De maneira semelhante, COUTO et al. (2016), avaliaram a eficácia do ozônio sobre $S$. aureus que é uma bactéria Gram positiva, em leite integral homogeneizado e em leite desnatado, nas concentrações de 34,7 e 44,8 $\mathrm{mg} / \mathrm{L}$ por até $25 \mathrm{~min}$. Os resultados indicaram baixa eficiência do ozônio sobre o desenvolvimento de $S$. aureus inoculado e interferência da a gordura do leite.

Quando se comparou a eficácia do ozônio na inativação de Lb. sakei no substrato LIH, verificou-se reduções inferiores a 0,1 ciclo log em todas as combinações de concentração do gás e período de exposição. No substrato LINH, foi possível a obtenção de redução equivalente a 0,30 ciclo $\log$, quando se adotou a concentração de $31 \mathrm{mg} / \mathrm{L}$, por período de exposição de 25 min. Tal comportamento pode estar relacionado ao diâmetro do glóbulo de gordura.

O substrato LIH é caracterizado por passar pelo processo de homogeneização, durante o qual ocorre redução do tamanho dos glóbulos de gordura e consequente aumento da área superficial, conforme apresentado por Berton et al., (2012). A redução no tamanho dos glóbulos de gordura e aumento da área superficial pode ter influenciado no processo de decomposição do ozônio e consequentemente na inativação dos microrganismos. A estabilidade do ozônio em meio aquoso é variável e influenciada pelo $\mathrm{pH}$, pela temperatura e pela presença de matéria orgânica. O gás pode oxidar os compostos ou espontaneamente decompor-se em oxigênio e radicais livres. Os mecanismos de decomposição do ozônio são processos complexos, que dependem de fatores como os tipos de radicais formados em solução e o tipo de matéria orgânica presente (LANGLAIS et al., 1991).

No processo de ozonização, a natureza dos compostos orgânicos presentes no meio determinará a reatividade com o gás. Compostos com grupos funcionais específicos, como anéis aromáticos e hidrocarbonetos insaturados, são propensos ao ataque do ozônio, já outros como hidrocarbonetos saturados, álcoois e aldeídos, são considerados resistentes.

Nesse sentido, a composição química do meio determina a reatividade potencial do ozônio. Em meio aquoso, o ozônio dissolvido se destaca por ser instável (BELTRAN, 2005). Ainda, de acordo com esse autor, existem dois períodos distintos na decomposição do ozônio. No primeiro, denominado de demanda rápida de ozônio, que varia 
apenas de alguns segundos até 2 min, ocorre consumo muito rápido do gás; durante o segundo período, a decomposição do ozônio ocorre lentamente, iniciando quando as substâncias orgânicas são degradadas ou suas concentrações diminuem.

Assim, a inexpressiva redução na contagem de Lb. sakei nos substratos orgânicos LINH e LIH também pode estar relacionada à rápida decomposição do ozônio. Nesse contexto, provavelmente ocorreu rápida decomposição do ozônio nos substratos, o que implicou na inexpressiva redução na contagem do microrganismo. Esse resultado deve ser considerado interessante, pois esse microrganismo é amplamente utilizado em processos fermentativos de diversos alimentos (ESPÍRITO SANTO et al., 2003; SOUZA et al., 2006; AFONSO, 2014).

As características físico-químicas dos substratos avaliados não foram alteradas em decorrência do processo de ozonização nas concentrações de 21 e $31 \mathrm{mg} / \mathrm{L}$ por até $25 \mathrm{~min}$, exceto no substrato LINH. Resultados semelhantes foram obtidos em pesquisa realizada por Santos (2013), uma vez que análises físico-químicas não apresentaram alterações significativas nos parâmetros do leite cru que foi submetido à ozonização a uma concentração de $3 \mathrm{mg} / \mathrm{L}$ por 0,75 min, 1,5 min. Entretanto houve significativa redução de gordura, extrato seco desengordurado, lactose, densidade e proteína apenas no binômio $18 \mathrm{mg} / \mathrm{L}$ por 10 minutos. 


\section{CONCLUSÃO}

A eficiência do ozônio no controle de microrganismos indicadores da qualidade higiênica e sanitária como E. coli está diretamente relacionada à composição e à quantidade de matéria orgânica presente no substrato, sendo necessária prévia remoção.

A maior resistência ao ozônio demonstrada por Lactobacillus sakei subsp. sakei indica que a atividade de bactérias ácido láticas inoculadas em substrato orgânico, não é significativamente afetada pelo gás, nas condições avaliadas.

A aplicação do gás ozônio em concentrações de até $31 \mathrm{mg} / \mathrm{L}$ por 25 min, não causa alterações nos principais componentes do leite. 


\section{REFERÊNCIAS}

AFONSO, A. F. P. Efeito da fermentação com Lactobacillus sakei produtores de antagonismo no controle de Listeria monocytogenes e Salmonella spp. em chouriço de vinho (Dissertação) - Mestrado em Biotecnologia e Qualidade Alimentar, p.85, 2014.

ANDRADE, C. L. Histopatologia e identificação da Escherichia coli como agente causal da celulite aviária em frangos de corte. (Tese) - Dissertação de Mestrado (Mestrado em Med. Veterinária) - Universidade Federal Fluminense, Rio de Janeiro, p.62, 2005.

ARGOV, N.; LEMAY, D. G.; GERMAM, J. G. Milf fat globule structure and function: nanoscienc comes to milk production. Trends in Food Science \& Technology, v. 19, n. 12, p. 617-623, 2008.

ARTÉS, F.; GÓMEZ, P.; AGUAYO, E.; ESCALONA, V.; FRANCISCO ARTÉSHERNÁNDEZ, F. Sustainable sanitation techniques for keeping quality and safety of fresh-cut plant commodities. Postharvest Biology and Technology, v. 51, n. 3, p. 287296, march, 2009.

ASAO, T., et al. An extensive outbreak of staphylococcal food poisoning due to low-fat milk in Japan: estimation of enterotoxin A in the incriminated milk and powdered skim milk. Epidemiology \& Infection, v. 130, n. 1, p. 33-40, 2003.

AXELSSON, L. Lactic acid bacteria: classification and physiology. FOOD SCIENCE AND TECHNOLOGY-NEW YORK-MARCEL DEKKER-, v. 139, p. 1-66, 2004.

BARNES, H. J.; VAILlANCOURT, J. P.; GROSS, W. B. Colibacillosis In: SAIF W. M. Diseases of poultry. (11 a ed.). Iowa, p. 138-144, 2003.

BATRINON, A. and LABITTE, T. The use of lactic acid bacteria in probiotic products, p.17-27, 2010.

BAUMAN, D. E. and LOCK, A. L. Concepts in lipid digestion and metabolism in dairy cows. In: TRI-STATE DAIRY NUTRITION CONFERENCE, 2007, Ohio. Proceedings... Ohio: Ohio State University, p. 1-14, 2006. 
BELTRÁN, F.J. Ozone reaction kinetics for water and wastewater systems. Boca Raton: CRC Press, p. 358, 2005.

BERTON, A.; ROUVELLAC, S.; ROBERT, B.; ROUSSEAU, F.; LOPEZ, C.; CREMON, I.

Effect of the size and interface composition of milk fat globules on their in vitro digestion by the human pancreatic lipase: native versus homogenized milk fat globules. Food Hydrocolloids, v. 29, n.1, p. 123-134, 2012.

BERNADEAU, M.; VERNOUX, J. P.; HENRI-DUBERNT, S.; e GUEGUEN, M. Safety assessment of dairy microorganisms: the Lactobacillus genus. International Journal of Food Microbiology, v. 126, n.3, p. 278-285, 2008.

BRASIL. Agência Nacional de Vigilância Sanitária. Portaria nº 29, de 13 de janeiro de 1998 (Versão Republicada -30.03.1998) ementa não oficial: Aprova o Regulamento Técnico referente a Alimentos para Fins Especiais. D.O.U. - Diário Oficial da União; Poder Executivo, de 30 de março de 1998.

BRASIL. Ministério da Agricultura, Pecuária e Abastecimento - MAPA. Instrução Normativa $n^{\circ}$ 62, de 29 de dezembro de 2011. Regulamento Técnico de Produção, Identidade e Qualidade do Leite tipo A, Identidade e Qualidade de Leite Cru Refrigerado, Identidade e Qualidade de Leite Pasteurizado e Coleta de Leite Cru Refrigerado e seu Transporte a Granel. D.O.U. - Diário Oficial da União; de 29 de Dezembro de 2011.

BRUNO, L. M.; CARVALHO, J. D. G. Microbiota Lática de Queijos Artesanais. Embrapa Agroindústria Tropical, Fortaleza, CE, 2009.

CALIL, E. M. B.; FERREIRA, A. L. F.; BRAZÃO, S. C.; SOVENHI, C. C. Qualidade microbiológica de saladas oferecidas em restaurantes tipo self-service. Atas de Saúde Ambiental-ASA, v. 1, n. 1, p. 36-42, 2014.

CAMPOS, L. C. e TRABULSI, L. R. Escherichia. In.: TRABULSI, L.R. et al. Microbiologia. 3 ed. São Paulo : Atheneu, p. 215-228, 2002.

CARDOSO, C. C.; VEIGA, S. M. O. M.; NASCIMENTO, L. C.; FIORINI, J. E.; AMARAL, L. A. Avaliação microbiológica de um processo de sanificação de galões de água com a utilização do ozônio. Ciência e Tecnologia dos Alimentos, Campinas, v. 23, n. 1, p. 5961, jan./abr. 2003.

CASTILLO, A. Ozone treatment for reduction of Escherichia coli O157:H7 and Salmonella serotype typhimurium on beef carcass surfaces, Journal of Food Protection, v. 66, n. 5, p. $775-779,2003$. 
CAVAlCANTE, D. A., LeITE JUNIOR B. R. C., TRIBST A. A. L., CRISTIANINI M. Sanitização de alface americana com água ozonizada para inativação de Escherichia coli O157:H7. Segurança Alimentar e Nutricional, v. 21, n.1, p. 373-378, 2014.

CLESCERI, L. S.; GREENBERG, A.E. EATON, A.D. Standard methods for the examination of water and wastewater. Denver: American Water Works Association, p. $1220,2000$.

COELHO, C. S. C.; SILVA, O. F.; CAMPOS, R. S.; BEZERRA, V. S.; CABRAL, L. M. C. Ozonização como tecnologia pos-colheita na conservação de frutas e hortaliças: uma revisão. Revista Brasileira de Engenharia Agrícola e Ambiental, v.19 n4. P. 369-375, 2015.

COUTO, E. P.; AlEnCAR, E. R.; GONÇAlVES, V. S. P., dos SANTOS, A. J. P., RIBEIRO, J. L.; FERREIRA, M.A. Efeito da ozonização sobre a contagem da Staphylococcus Aureus inoculado em leite. Semina: Ciências Agrárias, v. 37, n. 4, p. 1911-1918, 2016.

CROXEN, M. A.; FINLAY, B. B. Molecular mechanisms of Escherichia coli pathogenicity. Nature, v. 8, n, 1, p. 20-38, 2010.

DEVALENNE, E.; MOUNIER, J.; DÉNIEL, F.; BARBIER, G.; LE BLAY, G. Biodiversity of antifungal lactic acid bacteria isolated from raw milk samples from cow, ewe and goat over one-year period. International Journal of Food Microbiology, v. 155, p. 185-190, 2012.

EUROPEAN CENTRE FOR DISEASE PREVENTION AND CONTROL (ECDC). Outbreak of Shiga toxin-producing E. coli in Germany (14 June 2011, 11:00). Available from:http://ecdc.europa.eu/en/activities/sciadvice/Lists/ECDC\%20Reviews/ECDC_Disp Form.aspx?List=512ff74f\%2D77d4\%2D4ad8\%2Db6d6\%2Dbf0f23083f30\&ID=1112\&R ootFolder=\%2Fen\%2Factivities\%2Fsciadvice\%2FLists\%2FECDC\%20Review.

FEITOSA, T.; BORGES, M. F.; NASSU, R. T.; AZEVEDO, E. H. F.; MUNIZ, C. R. Pesquisa de Salmonella sp., Listeria sp. e microrganismos indicadores higiênico-sanitário em queijo de coalho produzido no Estado do Rio Grande do Norte. Ciência e Tecnologia de Alimentos, v. 23, p.162-165, 2003. Suplemento.

FRANCO, B. D. G. M. e LANDGRAF, M. et al. Microbiologia dos Alimentos. São Paulo: Ed. Atheneu, p. 196, 2008.

GEHR, R.; WAGNER, M.; VEERASUBRAMANIAN, P.; PAYMENT, P. Disinfection efficiency of peracetic acid, UV and ozone after enhanced primary treatment of municipal wastewater. Water Research, v. 37, n. 19, p. 4573-4586, 2003. 
GEROSA, S.; SKOET, J. Milk Availability: Trends in Production and Demand and MediumTerm Outlook ESA Working Paper No. 12-01. February 2012. Available online: http://www.fao.org/docrep/015/an450e/an450e00.pdf.

GILLILAND, S. E.; REILLY, S. S.; KIM, G. B.; KIM, H. S. Viability during storage of selected probiotic lactobacilli and bifidobacteria in a yogurt-like product. Journal of Food Science, v. 67, n. 8, p. 3091-3095, 2002.

GOMES, A. M. P.; MALCATA, F. X. Bifidobacterium spp. and Lactobacillus acidophilus: biological, biochemical, technological and therapeutical properties relevant for use as probiotics. Trends in Food Science \& Technology, v. 10, n. 4, p. 139-157, 1999.

GONZALEZ-AGUILAR, G. A.; VILLA-RODRIGUEZ, J. A.; AYALA-ZAVALA, J. F.; YAHIA, E. M. Improvement of the antioxidant status of tropical fruits as a secondary response to some postharvest treatments. Trends in Food Science \& Technology, v. 21, n. 10, p. 475-482, 2010.

GHODDUSI, H. B. Biotechnology of Lactic Acid Bacteria: Novel Applications, 2011.

GRAVES, T.; NARENDRANATH, V. N.; DAWSON, K.; POWER, R. Interaction effects of lactic acid and acetic acid at different temperatures on ethanol production by Saccharomyces cerevisiae in corn mash. Applied Microbiology and Biotechnology, v. 73, n. 5, p. 1190-6, (2007).

GUZEL-SEYDIM, Z. B.; BEVER JUNIOR, P. I.; GREENE, A. K. Efficacy of ozone to reduce bacterial populations in the presence of food components. Food Microbiology, London, v. 21, n. 4, p. 475-479, 2004 b.

GUZEL-SEYDIM, Z. B.; GREENE, A. K.; SEYDIM, A. C. Use of ozone in the food industry. Swiss Society of Food Science and Technology. Published by Elsevier Ltd. Lebensmittel -Wissenschaft und -Technologie. v. 37, n. 4, p. 453-460. 2004a.

HOLTZ, S. G. Aplicação de ozônio e de revestimentos comestíveis em morangos (Frangaria ananassa Duch.) minimamente processados. 2006. (Dissertação) Mestrado em Microbiologia Agrícola, p. 93, Universidade Federal de Viçosa - Viçosa, Minas Gerais.

HOLT, J. G.; KRIEG, P. H. A. Bergey's manual of determinative bacteriology. $9^{\text {th }}$ ed. Philadelphia: Lippincott Williams \& Wilkins, 1994. p.787, HUNT, N. K.; MARIÑAS, B. J. Inactivation of Escherichia coli with ozone: chemical and inactivation kinetics. Water Research, Kidlington, v. 33, n. 11, p. 2633-2641, 1999.

JAY, J. M. Microbiologia de alimentos. 6 ${ }^{\mathrm{a}}$ Ed. Porto Alegre: Artmed, 2005.

JYOTI, K. K. and PANDIT, A. B. Hybrid cavitation methods for water disinfection.

Biochemical Engineering Journal, v. 14, n. 1, p. 9-17, 2003. 
JYOTI, K. K. and PANDIT, A. B. Ozone and cavitation for water disinfection. Biochemical Engineering Journal, v. 18, n. 1, p. 9-19, 2004.

KELLS, S. A.; MASON, L. J.; MAIER, D. E.; WOLOSHUK, C. P. Efficacy and fumigation characteristics of ozone in stored maize. Journal of Stored Products Research, v. 37, n. 4, p. 371-383, 2001.

KONDYLI, E.; SVARNAS, C.; SAMELIS, J.; KATSIARI, M. C. Chemical composition and microbiological quality of ewe and goat milk of native Greek breeds. Small Ruminant Research, v. 103, n. 2, p. 194-199, 2012.

LANGLAIS, B.; RECKHOW, D. A.; BRINK, D. R. Ozone in water treatment: application and engineering. Chelsea: AWWARF and Lewis Publishers, p. 568, 1991.

LEZCANO, I.; PÉREZ REY, R.; GUTIÉRREZ, M. S.; BALUJA, C.; SÁNCHEZ, E. Ozone inactivation of microorganisms in water: Gram positive Bacteria and yeast. Ozone: science \& engineering, v. 23, n.2, p. 183-187, 2001.

LIU, S. N.; HAN, Y.; ZHOU, Z. J. Lactic acid bacteria in traditional fermented chinese foods. Food Research International, v.44, p.643-651, 2011.

LONGO, G. Influência da adição de lactase na produção de iogurtes. Curitiba, (Dissertação)Mestrado em Tecnologia de Alimentos - Universidade Federal do Paraná, p.89, 2006.

LOPÉZ-DIAZ, T. M.; ALONSO, C.; ROMAN, C.; GARIA-LOPEZ, M. L.; MORENO, B. Lactic acid bacteria isolated from a hand-made blue cheese. Food Microbiology, v. 17, n.1, 23-32, 2000.

LÓPEZ-GÁlVEZ, F.; GIL, M. I.; TRUCHADO, P.; SELMA, M. V.; ALLENDE, A. Crosscontamination of fresh-cut lettuce after a short-term exposure during pre-washing cannot be controlled after subsequent washing with chlorine dioxide or sodium hypochlorite. Food Microbiology, v. 7, n. 2, p. 199 - 204, 2010.

LULLIEN-PELLERIN, V. Ozone in grain processing. In: O’DONNELL, C. P., et al. Ozone in Food Processing, $1^{\text {a }}$ ed., Blackwell Publishing, 2012.

MAISTRO, L. C. Alface minimamente processada: uma revisão. Revista de Nutrição, São Paulo, v.14, n. 3, p. 119-224, set./dez. 2001.

MCLEOD, A.; ZAGOREC, M.; CHAMPONIER-VERGÈS, M. C.; NATERSTAD, K.; AXELSSON, L. Primary metabolism in Lactobacillus sakei food isolates by proteomic analysis. BMC microbiology, v. 10, n. 1, p. 120, 2010.

NASCIMENTO, D.; Substitutos para o enxofre. Revista IDEANEWS, a.05, n. 56, p. 06-18, marc, 2006. 
NASCIMENTO, L. C. et al. Uso de derivados clorados, ozônio e ultra-som na sanificação de água e alimentos - revisão. Higiene Alimentar, São Paulo, v. 19, n. 136, p. 48-57, out. 2005.

OLIVEIRA, W. F. et al. Utilização de diferentes meios de cultura para o isolamento de enterobactérias em amostras fecais de frangos de corte procedentes de explorações industriais do Estado do Ceará, Brasil. RPCV, v. 99, n. 552, p. 211-214, 2004.

OLIVEIRA, L. P.; BARROS, L. S. S.; SILVA, V. C. Avaliação fisico-química de leite cru e pasteurizado consumido no Recôncavo da Bahia. Enciclopédia Biosfera, v. 8, p. 335$343,2012$.

OlIVEIRA, E. C. M.; VAlLE, R. H. P.do. Aspectos Microbiológicos dos Produtos Hortícolas Minimamente Processados. Higiene Alimentar, v. 11, n. 78/79, p. 50-54, 2000.

ÖLMEZ, H.; KRETZSCHMAR, U. Potential alternative disinfection methods for organic fresh-cut industry for minimizing water consumption and environmental impact. Food Science and Technology, v. 42, n. 3, p. 686-693, 2009.

PASCUAL, A., LLORCA, I.; CANUT, A. Use of ozone in food industries for reducing the environmental impact of cleaning and disinfection activities. Trends in Food Science $\&$ Technology, v. 18, p. S29-S35, 2007.

POHLMAN, F., W. Ozone in meat processing. In: O’DONNELL, C. P., et al. Ozone in Food Processing, $1^{\mathrm{a}}$ ed., Blackwell Publishing, 2012.

PRESTES, E. Avaliação da eficiência do ozônio como sanitizante em hortaliças folhosas minimamente processadas. Tese (Doutorado em Tecnologia de Alimentos) Universidade Estadual de Campinas Campinas, p.135, 2007.

QUINN, P. J.; MARKEY, B. K.; CARTER, M. E.; DONNELLY, W. J.; LEONARD, F. C. Microbiologia Veterinária e Doenças Infecciosas. $1^{\text {a }}$ ed. Porto Alegre: editora Artmed, p. 512, 2005.

RESTAINO, L., et al. Efficacy of ozonated water against various food-related microorganisms. Applied Environmental Microbiology, v. 61, n. 9, p. 3471-3475, 1995.

RICO, D.; MARTÍN-DIANA, A. B.; BARAT, J. M.; BARRY-RYAN, C. Extending and measuring the quality of fresh-cut fruit and vegetables: a review. Trends in Food Science and Technology, v. 18, n. 7, p. 373-386, 2007.

RUSSEL, A. D.; HUGO, W. B.; AVLIFFE, G. A. J. Principles and practice of disinfection, preservation and sterilization. 3. ed. Oxford: Blackwell Science, p. 826, 1999. 
SANTANA, E. H. W.; BELOTI, V.; OLIVEIRA, T. C. R. M.; MORAES, L. B.; TAMANINI, R.; SILVA, W. P. Estafilococos: morfologia das colônias, produção de coagulase e enterotoxina a, em amostras isoladas de leite cru refrigerado, Semina: Ciências Agrárias, Londrina, v. 27, n. 4, p. 639-646, out./dez. 2006.

SANTOS, A. J. P. Avaliação da utilização de ozônio como método de beneficiamento de leite. (Monografia)- Universidade de Brasília, p. 46, 2013.

SANTO, M. L. P. E.; BEIRÃO, L. H., SANT'ANNA, E. R. N. A. N. I.; DAMIAN, C.; FRANCO, B. M. Avaliação da atividade bacteriocinogênica do Lactobacillus sakei na fermentação da sardinha-verdadeira (Sardinella brasiliensis) utilizando glicose como carboidrato fermentecível Boletim do Centro de Pesquisa de Processamento de Alimentos, v. 21, n.1, 2003.

SAVIOLLI, J.Y. Pesquisa e caracterização de Escherichia coli patogênica (E. coli produtora de toxina Shiga - STEC; E. coli aviária patogênica - APEC) de fragatas (Fregata magnificens) da Costa do Estado de São Paulo. (Dissertação) - Mestrado. Universidade de São Paulo, p. 84, 2010.

SCALLAN, E., HOEKSTRA, R.M., ANGULO, F.J., TAUXE, R.V., WIDDOSON, M.A., RO Y, S.L., Foodborne illness acquired in the United States-major pathogens. Emerging Infectious Diseases, v. 17, n. 1, 2011.

SCHITTLER, L. Isolamento e caraterização fenotípica e molecular de bactérias ácido láticas bacteriocinogênicas em leite in natura da região oeste de Santa Catarina. (Tese) Doutorado em Ciências e Tecnologia Agroindustrial, p. 92, Pelotas, 2012.

SHEELAMARY, M. and MUTHUKUMAR, M. Effectiveness of Ozone in Inactivating Listeria monocytogenes from Milk Samples. World Journal Young Researchers, v. 1, n. 3, p. 40-44, 2011.

SILVA, J.; CARVALHO A.S.; TEIXEIRA, P.; GIBBS, P.A Bacteriocin production by spraydried lactic acid bacteria. Letters in Applied Microbiology, v. 34, p. 77-81, 2002.

SILVA, B.; LUVIELMO, S. M.; CURTINOVI; G. M.; IVANA; P. Potencialidades do uso do ozônio no processamento de alimentos. Semina: Ciências Agrárias, v. 32, n. 2, p. 659$682,2011$.

SOUZA, J.; RODRIGUES, L. G. G.; GONZALEZ, P. N. M.; TORTATO, R.; CARBONEA, N.; ESPÍRITO SANTO, M. L. P. Atividade antimicrobiana do Lactobacillus sakei na fermentação do bonito-de-barriga-listrada (Euthynnus pelamis), v. 16, p. 25-36, 2006.

SUNG, H. J; SONG, W. J.; KIM, K. P.; RYU, S.; KANG, D. H. Combination effect of ozone and heat treatments for the inactivation of Escherichia coli O157: H7, Salmonella 
Typhimurium, and Listeria monocytogenes in apple juice. International journal of food microbiology, v.171, p. 147-153, 2014.

TALBOT, P.; MARTINELli, L.; TALVY, S.; CHAUVEHEID, E.; HAUT, B. Ozone inactivation of resistant microorganisms: Laboratory analysis and evaluation of the efficiency of plants. Water Research, v. 46, n. 18, p. 5893-5903, 2012.

TIWARI, B. K. and MUTHUKUMARAPPAN, K.Ozone in fruit and vegetable processing. In: O’DONNELL, C. P., et al. Ozone in Food Processing, $1^{\text {a }}$ ed., Blackwell Publishing, 2012.

TORO, C.R. Uso de bactérias láticas probióticas na alimentação de camarões Litopenaeus vannamei como inibidoras de microrganismos patogênicos e estimulantes do sistema imune. (Tese) Doutorado em Processos Biotecnológicos - Universidade Federal do Paraná, Curitiba, p. 153, 2005.

TORTORA, G. J.; FUNKE, B. R.; CASE, L. C. Microbiologia - 10. Edição - Porto Alegre: Artmed, 2012.

TRONCO, V. M. Manual para Inspeção de Qualidade do Leite. Santa Maria: Ed. Universidade Federal de Santa Maria, p. 203, 2010.

VAEREWIJCK, M. J. M.; DE VOS, P.; LEBBE, L.; SCHELDEMAN, P.; HOTE, B.; HEYNDRICKX, M. Ocurrence of Bacillus sporothermodurans and other aerobic sporeforming species in feed concentrate for dairy cattle. Journal of Applied Microbiology, v. 91, p. 1074-1084, 2001.

VEIGA, S. M. O. M. Sanificação de carcaças de frango: processos alternativos. Lavras, (Tese) Doutorado em Ciência dos Alimentos - Universidade Federal de Lavras, p. 291, 2003.

VELANO, H. E.; NASCIMENTO, L. C.; BARROS, L. M.; PANZERI, H. Avaliação in vitro da atividade antibacteriana da água ozonizada frente ao Staphylococcus aureus. Pesquisa Odontológica Brasileira, v. 15, n. 1, p. 18-22, 2001.

WERLANG, G. O. Eficácia da aplicação de ozônio gasoso em carcaças suínas na etapa de resfriamento para o controle de bactérias indicadoras e causadoras de doenças transmitidas por alimentos. (Dissertação) - Mestrado - Universidade Federal do Rio Grande do Sul. Faculdade de Veterinária. Programa de Pós-Graduação em Ciências Veterinárias, p. 63, 2015.

WIDYASTUTI, Y.; ROHMATUSSOLIHAT, FEBRISIANTOSA, A. The role of lactic Acid Bacteria in Milk Fermentation. Food and Nutrition Sciences, v. 5, n. 4, p. 435-442, 2014. 
XU, P.; JANEX, M.L.; SAVOYE, P.; COCKX, A.; LAZAROVA, V. Wastewater disinfection by ozone: main parameters for process design. Water Research, v. 36, n. 4, p. 10431055, 2002. 


\section{CAPÍTULO III}

EFEITOS DA APLICAÇÃO DIRETA E INDIRETA DE OZÔNIO SOBRE ESCHERICHIA COLI O157:H7 INOCULADA EM DIFERENTES SUBSTRATOS. 


\title{
EFEITOS DA APLICAÇÃO DIRETA E INDIRETA DE OZÔNIO SOBRE ESCHERICHIA COLI O157:H7 INOCULADA EM DIFERENTES SUBSTRATOS.
}

\begin{abstract}
RESUMO
O ozônio é utilizado em função de sua comprovada capacidade de inativar diversos microrganismos. Entretanto, ainda são poucos os trabalhos que avaliem a interferência de substratos orgânicos na ação do ozônio sobre patógenos, assim como a eficácia da aplicação direta do gás e indireta, por meio de contato com a água ozonizada. As infecções pela bactéria patogênica Escherichia coli O157:H7 podem evoluir para quadros graves, pelo desenvolvimento da síndrome hemolítica urêmica e serem responsáveis pela alta taxa de mortalidade nos indivíduos acometidos. O objetivo da pesquisa foi avaliar a interferência da composição de substratos orgânicos na eficiência do ozônio gasoso sobre Escherichia coli O157:H7 e a eficácia da água ozonizada armazenada refrigerada sobre essa espécie. As cepas de $E$. coli $\mathrm{O} 157: \mathrm{H} 7\left(\mathrm{ATCC}{ }^{\circledR}\right.$ 43890 ${ }^{\mathrm{TM}}$ ) foram inoculadas em leites de diferentes composições: integral homogeneizado com lactose, integral homogeneizado sem lactose, desnatado homogeneizado com lactose, desnatado homogeneizado sem lactose e, integral sem homogeneização. Como parâmetro de comparação, foram avaliados os mesmos tratamentos em água. O ozônio gasoso foi utilizado nas concentrações de 21 e $31 \mathrm{mg} / \mathrm{L}$ por $0,5,15$ e 25 min. Para a obtenção da água ozonizada, a concentração do gás foi de $31 \mathrm{mg} / \mathrm{L}$ e o período de exposição de $15 \mathrm{~min}$. Adotou-se período de contato de $5 \mathrm{~min}$, na avaliação da eficácia da água ozonizada e estocada sob refrigeração $\left(7^{\circ} \mathrm{C} \pm 1^{\circ} \mathrm{C}\right)$ por $0 ; 0,5 ; 1,0 ; 1,5 ; 3,0$ e $24 \mathrm{~h}$, no controle de E. coli O157:H7. Para as contagens foi utilizado o meio Violet Red Bile (VRB). Adotou-se o Delineamento Inteiramente Casualizado, com três repetições. Verificou-se, a partir dos resultados obtidos, que a composição dos substratos orgânicos interfere na ação do ozônio sobre E. coli $\mathrm{O} 157: \mathrm{H7}$, nas diferentes combinações de concentração do gás e período de exposição. Quando se avaliou a ação do ozônio sobre E. coli O157:H7 em substrato orgânicos, as maiores reduções foram no leite desnatado homogeneizado sem lactose onde obtidas reduções em torno de 1,5 ciclos log, para períodos de exposição de $25 \mathrm{~min}$, nas concentrações do ozônio testadas. Por outro lado, nos substratos leite integral homogeneizado com lactose e leite desnatado homogeneizado com lactose, as reduções na contagem de $E$. coli O157:H7 permaneceram inferiores a 0,40 ciclo log, em todas as combinações de concentração do ozônio e períodos de exposição ao gás. Obteve-se a máxima redução possível, levando-se em consideração o inóculo inicial e a técnica de quantificação adotada, quando utilizada a água como substrato. No que se refere à eficácia da água ozonizada na inativação de $E$. coli O157:H7 por período de contato de 5 min, obteve-se redução de aproximadamente 4,5 ciclos log para todos os períodos de armazenamento refrigerado. Concluiu-se que a ação do ozônio sobre E. coli O157:H7 é influenciada pela composição dos substratos orgânicos diminuindo a sua eficácia como sanitizante e reforçando a necessidade de remoção adequada de matéria orgânica nos processos de limpeza e que, a água ozonizada refrigerada por até 24 h é eficaz no controle de $E$. coli $\mathrm{O} 157: \mathrm{H7}$, podendo representar uma alternativa a outros sanitizantes.
\end{abstract}

Palavras-chave: leite, ozonização, sanitização, higienização de equipamentos, biofilmes. 


\title{
EFFECTS OF THE DIRECT AND INDIRECT APPLICATION OF OZONE ON ESCHERICHIA COLI O157: H7 INOCULATED IN DIFFERENT SUBSTRATES.
}

\begin{abstract}
Ozone is used because of its proven ability to inactivate various microorganisms. However, there are still few studies that evaluate the interference of organic substrates in the action of ozone on pathogens, as well as the effectiveness of direct and indirect gas application through ozonated water. Escherichia coli O157: H7 infections can progress to severe conditions by the development of hemolytic uremic syndrome and be responsible for the high mortality rate in the affected individuals. The objective of this research was to evaluate the interference of organic substrate composition on the efficiency of ozone gas over Escherichia coli O157: H7 (ATCC® $43890^{\mathrm{TM}}$ ) and the efficacy of refrigerated stored ozonated water on this species. The strains of E. coli O157: H7 were inoculated in different types of milk: homogenized integral with lactose, homogenized integral without lactose, skimmed homogenized with lactose, skimmed homogenized without lactose and, integral without homogenization. As a parameter of comparison, the same treatments in water were evaluated. Gaseous ozone was used at concentrations of 21 and $31 \mathrm{mg} / \mathrm{L}$ for $0,5,15$ and 25 minutes. To obtain ozonated water, the gas concentration was $31 \mathrm{mg} / \mathrm{L}$ and the exposure period was $15 \mathrm{~min}$. A 5-minute contact period was used to evaluate the efficacy of ozonated water stored under refrigeration $(7 \mathrm{oC} \pm 1 \mathrm{oC}$ ) by $0 ; 0.5 ; 1.0 ; 1.5 ; 3.0$ and $24 \mathrm{~h}$ in the control of E. coli O157: H7. Violet Red Bile medium (VRB) was used for the counts. We adopted a completely randomized design with three replicates. It was verified from the obtained results that the composition of the organic substrates interferes in the action of the ozone on E. coli O157: H7, in the different combinations of gas concentration and exposure period. When the action of ozone on E. coli O157: H7 on organic substrates was evaluated, the greatest reductions were in non-lactose homogenized skim milk. In non-lactose homogenized skim milk, reductions of 1.5 log cycles were obtained for $25 \mathrm{~min}$ exposure periods at the tested ozone concentrations. On the other hand, on the substrates homogenized milk with lactose and skim milk homogenized with lactose, the reductions in the E. coli O157: H7 count remained below 0,40 log cycles, in all combinations of ozone concentrations and exposure periods to gas. The maximum possible reduction was obtained, taking into account the initial inoculum and the technique of quantification adopted, when water was used as substrate. Regarding the efficacy of ozonated water in the inactivation of $E$. coli $\mathrm{O} 157$ : $\mathrm{H} 7$ per contact period of 5 minutes, a reduction of approximately $4.5 \mathrm{log}$ cycles was obtained for all periods of refrigerated storage. It was concluded that the action of ozone on E. coli O157: $\mathrm{H} 7$ is influenced by the composition of the organic substrates reducing their effectiveness as sanitizing agent and reinforcing the need for adequate removal of organic matter in the cleaning processes and that ozonated water cooled by up to 24 hours is effective in the control of E. coli O157: H7, and may represent an alternative to other sanitizers.
\end{abstract}

Keywords: milk, ozonization, sanitization, equipment hygiene, biofilms. 


\section{INTRODUÇÃO}

Pertencente à família Enterobacteriaceae, o gênero Escherichia compreende as espécies E. coli, E. blattae, E. fergusonii, E. hermanii, E. vulneris. No entanto, a espécie de importância é E. coli (CAMPOS e TRABULSI, 2002). E. coli é uma bactéria Gram negativa e uma das principais constituintes da microbiota intestinal de humanos e de animais. Acreditase que a maioria dos sorotipos de E. coli seja desprovida de qualquer fator de virulência, entretanto algumas cepas adquiriram, durante o processo evolutivo, diferentes conjuntos de genes que lhes conferiram a capacidade de ocasionar doença, fato que determina a grande versatilidade patogênica da espécie (CHERNAKI-LEFFER et al., 2002).

As EHEC ou E. coli produtoras de toxina Shiga (STEC) são também chamadas de E. coli verotoxigênicas ou, produtoras de verotoxinas (VTEC) e compõem um importante grupo de patógenos emergentes transmitidos por alimentos (BEUTIN et al., 2002; BLANCO et al., 2003; BOSILEVAC e KOOHMARAIE, 2011; PIANCIOLA et al., 2014).

De acordo com o Centers for Disease Control and Prevention (CDC) A maioria dos surtos causados por E. coli $\mathrm{O} 157: \mathrm{H} 7$ tem sido relacionada, principalmente, ao consumo de carne moída mal cozida (CDC, 2014). No entanto, atualmente, surtos envolvendo alimentos não cárneos como leite e seus derivados não pasteurizados; sucos de frutas não pasteurizados; alface; espinafre; legumes crus e brotos de semente também tem sido relatados (LUND e O'BRIEN, 2009; FENG et al., 2011; LIU et al., 2015).

Dentre os sanitizantes empregados na indústria de alimentos, predominam os à base de cloro e compostos clorados (NASCIMENTO et al., 2003; CHEN e ZHU, 2011; CHEN et al., 2013). A facilidade do uso, o baixo custo, a atividade antimicrobiana e a completa dissolução em água, fazem com que os agentes clorados sejam frequentemente utilizados como sanitizantes na indústria alimentícia (SELMA et al., 2008; NASCIMENTO et al., 2003; SHEN et al., 2012). 
Considerando a importância da etapa de sanitização, o estudo de métodos e/ou agentes alternativos devem receber atenção especial. O ozônio apresenta-se como uma opção que pode ser utilizada com diferentes objetivos, dentre eles, a remoção de partículas aderidas a superfícies e a inativação de microrganismos. Essa tecnologia associada à sanitizantes permite maior redução da contaminação microbiana de alimentos (CHEMAT et al., 2011; CAVALCANTE et al., 2014; CAVALCANTE et al., 2015).

Como sanitizante, o ozônio atua primeiramente na membrana celular reagindo com glicoproteínas ou glicolipídeos. Além disso, promove a oxidação das organelas citoplasmáticas e do DNA no núcleo, degradando purinas e pirimidinas do DNA que resulta na morte celular (MACEDO, 2004). É efetivo em baixas concentrações e necessita de pequeno tempo de contato para inativar bactérias, fungos, leveduras, parasitas e vírus (KIM et al, 1999).

Embora o ozônio produza a inativação de vários microrganismos, ainda são necessários estudos que elucidem a sua eficácia na eliminação de E. coli O157:H7, além da determinação da concentração e da forma de aplicação, mais adequadas. Diante do exposto objetivou-se conhecer os efeitos da aplicação direta do ozônio sobre E. coli O157:H7 inoculada em diferentes substratos e a ação indireta a partir da água ozonizada de forma a avaliar o seu potencial como sanitizante, para possíveis uso em plantas de processamento de alimentos. 


\section{MATERIAIS E MÉTODOS}

A presente pesquisa foi realizada nos Laboratórios de Análises de Leite e Derivados e de Pré-Processamento e Armazenamento de Produtos Agrícolas, localizados na Faculdade de Agronomia e Medicina Veterinária, da Universidade de Brasília, no período de janeiro de 2014 a agosto de 2016. Nos dois estudos foi utilizada a cepa E. coli O157:H7 (ATCC $® 43890^{\mathrm{TM}}$ ) cedida pelo Laboratório de Inspeção de Produtos de Origem Animal, da Universidade Federal de Viçosa, $\mathrm{MG}$, e mantida a $-80^{\circ} \mathrm{C}$. As análises foram realizadas na capela de fluxo laminar, utilizando-se de todos os equipamentos de proteção. Antes de cada inoculação a cepa foi recuperada em Caldo Tripticase de Soja (TSB) (Bacto ${ }^{\text {TM}}$ ) com incubação a $35^{\circ} \mathrm{C}$ por 24 horas e após, semeada em Ágar Tripticase de Soja enriquecido com extrato de levedura (TSA-YE) (Kasvi®) e também, incubada a $35^{\circ} \mathrm{C}$ por 24 horas.

\subsection{EXPERIMENTO I}

Este estudo teve como objetivo avaliar o efeito da aplicação direta de ozônio no desenvolvimento de E. coli O157:H7 inoculada em substratos orgânicos e em água.

\subsubsection{Substratos orgânicos}

Como substratos orgânicos foram utilizados: Leite Integral Não Homogeneizado (LINH); Leite Integral Homogeneizado (LIH); Leite Desnatado (LD); Leite Desnatado Zero Lactose (LDZL); Leite Integral Zero Lactose (LIZL), obtidos de estabelecimentos comerciais, que foram esterilizados laboratorialmente, como forma de garantir a eliminação de qualquer outro microrganismo e resfriados antes das inoculações. Todos os procedimentos também foram conduzidos em água destilada utilizada como parâmetro de comparação. 


\subsubsection{Preparo dos inóculos}

Colônias desenvolvidas no TSA-YE foram inoculadas em solução salina $0,85 \%$ de forma a obter-se grau de turvação correspondente ao tubo 1 da escala nefelométrica de McFarland (Nefelobac $\AA$, Probac do Brasil), contendo aproximadamente 3,0 x $10^{8} \mathrm{UFC} / \mathrm{mL}$. A partir desse inóculo, 9,0 mL eram transferidos para balão volumétrico contendo $91 \mathrm{~mL}$ de cada substrato, como forma de se obter contagens aproximadas de $10^{6} \mathrm{UFC} / \mathrm{mL}$; após, 3,0 mL eram inoculados em $297 \mathrm{~mL}$ do substrato de forma a se obter aproximadamente $10^{4} \mathrm{UFC} / \mathrm{mL}$ (inóculo mãe).

\subsubsection{Aplicação do ozônio}

O gás ozônio foi obtido por meio de um gerador de ozônio (Modelo O\&L 3.0O2 RM, da Ozone \& Life®) baseado no método de Descarga por Barreira Dielétrica que é produzido ao aplicar uma alta tensão entre dois eletrodos paralelos, tendo entre eles um dielétrico (vidro) e um espaço livre por onde flui o ar seco. Neste espaço é produzida uma descarga em forma de filamentos, que gera elétrons com energia suficiente para produzir a quebra das moléculas de oxigênio $\left(\mathrm{O}_{2}\right)$, formando o ozônio $\left(\mathrm{O}_{3}\right)$. $\mathrm{O}$ insumo de oxigênio é obtido por concentrador de oxigênio acoplado ao gerador de ozônio.

A concentração de ozônio foi determinada pelo método iodométrico, descrito por Clesceri et al. (2000), onde o borbulhamento de massa gasosa contendo ozônio em $50 \mathrm{~mL}$ de solução de iodeto de potássio $(\mathrm{KI}) 1 \mathrm{~N}$, produz iodo $\left(\mathrm{I}_{2}\right)$. Para isso é necessário acidificar o meio com 2,5 mL de ácido sulfúrico $\left(\mathrm{H}_{2} \mathrm{SO}_{4}\right) 1 \mathrm{~N}$, depois do borbulhamento. A solução foi titulada com tiossulfato de sódio $\left(\mathrm{Na}_{2} \mathrm{~S}_{2} \mathrm{O}_{3}\right) 0,01 \mathrm{~N}$, com uso de solução de amido $1 \%$ como indicador.

Cada amostra de substrato foi transferida para uma coluna de vidro, com capacidade de $500 \mathrm{~mL}$, tendo $19 \mathrm{~cm}$ de altura e $6,0 \mathrm{~cm}$ de diâmetro. Antes da ozonização de cada amostra, a coluna de vidro foi sanitizada, com borbulhamento do próprio gás ozônio em água, por cinco minutos. Foi instalado o destruidor térmico catalítico depois da coluna de ozonização, necessária para decomposição do ozônio residual. 


\subsubsection{Binômios de concentração de ozônio $x$ tempo de exposição}

A partir de resultados obtidos em estudos anteriores desenvolvidos pelo grupo de pesquisa dos laboratórios envolvidos (SANTOS, 2013; COUTO et al., 2016) e por Sheelamary e Muthukumar, 2011, foram aplicadas as concentrações de $21 \mathrm{mg} / \mathrm{L}$ e de 31 $\mathrm{mg} / \mathrm{L}$, nos tempos de zero, cinco, quinze e vinte e cinco minutos para o microrganismo testado. Cada tratamento foi conduzido em triplicata.

\subsubsection{Análises microbiológicas dos substratos inoculados}

Para as semeaduras, foram realizadas diluições decimais seriadas, a partir do inóculo mãe (aproximadamente $10^{4} \mathrm{UFC} / \mathrm{mL}$ ). As contagens de E. coli O157:H7 (ATCC® $43890^{\mathrm{TM}}$ ), antes e após o processo de ozonização, foram realizadas por meio da semeadura de 0,1 mL em superfície, em ágar Violet Red Bile (VRB) (Acumedia®) com incubação a $35^{\circ} \mathrm{C}$ por 24 horas. Os resultados das contagens foram convertidos em $\log _{10}$.

\subsubsection{Análises físico-químicas}

As amostras foram analisadas quanto aos teores de proteína, lactose, gordura, sólidos não gordurosos e densidade por meio de equipamento ultrassonico EKOMILK (Ekomilk Total®).

\subsubsection{Delineamento Experimental}

Nessa etapa, que trata da avaliação da eficácia do ozônio gasoso no controle de Escherichia coli O157:H7, adotou-se o Delineamento Inteiramente Casualizado, em esquema em fatorial $2 \times 6 \times 4$, sendo duas concentrações do ozônio (21 e $31 \mathrm{mg} / \mathrm{L}$ ), seis substratos (LINH, LIH, LD, LDZL, LIZL e água) e quatro períodos de exposição ao gás $(0,5,15$ e 25 minutos), sendo cada ensaio conduzido em três repetições.

Foi realizada análise de variância a $5 \%$ de probabilidade, utilizando-se o software ASSISTAT 7.7 BET. Posteriormente realizou-se teste de média, utilizando-se o Teste de Tukey a 5\% de probabilidade ou análise de regressão. Análise de regressão foi adotada quando se avaliou o efeito do período de ozonização. Utilizou-se o software SigmaPlot na obtenção das equações de regressão e na plotagem dos gráficos. 


\subsection{EXPERIMENTO II}

Esse estudo objetivou avaliar o efeito da aplicação indireta de ozônio, a partir da água destilada ozonizada refrigerada e estocada por até 24 horas, sobre o desenvolvimento de E. coli $\mathrm{O} 157: \mathrm{H} 7$ (ATCC ${ }^{\circledR} 43890^{\mathrm{TM}}$ ), de forma a estabelecer seu potencial como solução sanitizante de circulação, para uso em plantas de processamento de alimentos.

\subsubsection{Preparo dos inóculos}

Colônias de E. coli O157:H7 desenvolvidas no TSA-YE foram inoculadas em solução salina $0,85 \%$ de forma a obter-se grau de turvação correspondente ao tubo 1 da escala nefelométrica de McFarland (Nefelobac $®$, Probac do Brasil), contendo aproximadamente 3,0 x $10^{8} \mathrm{UFC} / \mathrm{mL}$. A partir desse inóculo foi retirado $1,0 \mathrm{~mL}$ e realizadas diluições decimais seriadas em solução salina a $0,85 \%$ até a obtenção do inóculo de aproximadamente, $10^{4}$ UFC/mL (inóculo mãe).

\subsubsection{Obtenção do ozônio, tratamento da água destilada ozonizada e inóculos}

O gás ozônio foi obtido conforme descrito em 2.1.3. Para obtenção da água ozonizada, foram autoclavados $2000 \mathrm{~mL}$ de água destilada, por 30 minutos a $121^{\circ} \mathrm{C}$; após, a água foi transferida para coluna de vidro e ozonizada na concentração de $31 \mathrm{mg} / \mathrm{L}$ por 15 e mantidos sob refrigeração a $8^{\circ} \mathrm{C} \pm 1$. Em seguida, $9,0 \mathrm{~mL}$ de água ozonizada foram pipetados em tubos de ensaio esterilizados para a realização das inoculações que corresponderam tratamentos abaixo descritos. O tempo de contato dos inóculos com a água destilada ozonizada foi de cinco minutos.

- T0 = 1,0 mL de inóculo + 9,0 mL de água destilada imediatamente após a ozonização;

- $\mathbf{T 1}$ = 1,0 $\mathrm{mL}$ de inóculo + 9,0 mL de água destilada ozonizada e refrigerada por $30 \mathrm{~min}$;

- T2 = 1,0 mL de inóculo + 9,0 mL de água destilada ozonizada e refrigerada por $60 \mathrm{~min}$;

- T3 = 1,0 mL de inóculo + 9,0 mL de água destilada ozonizada e refrigerada por $90 \mathrm{~min}$;

- T4 = 1,0 $\mathrm{mL}$ de inóculo + 9,0 $\mathrm{mL}$ de água destilada ozonizada e refrigerada por $180 \mathrm{~min}$;

- T5 = 1,0 mL de inóculo + 9,0 mL de água destilada ozonizada e refrigerada por $24 \mathrm{~h}$; 


\subsubsection{Mensuração do ozônio residual na água}

A quantificação do ozônio dissolvido na água foi realizada em fotômetro SAM Chemetrics, Modelo I-2019, com faixa de medição de 0,2 a 5,0 mg/L.

\subsubsection{Contagens microbiológicas}

Para as contagens de E. coli $\mathrm{O} 157: \mathrm{H} 7$ inoculada em água destilada ozonizada, as semeaduras foram realizadas em superfície $(0,1 \mathrm{~mL})$ em ágar VRB com incubação a $35^{\circ} \mathrm{C}$ por 24 horas. Os resultados das contagens foram convertidos em $\log _{10}$.

\subsubsection{Delineamento Experimental}

Na segunda etapa, na qual se avaliou a eficácia da água ozonizada no controle de E. coli $\mathrm{O} 157: \mathrm{H} 7$, variou-se somente o período de armazenamento da água ozonizada (0; 0,$5 ; 1,0 ; 1,5 ; 3,0$ e 24 h). Utilizou-se estatística descritiva na apresentação e análise dos dados. 


\section{RESULTADOS}

De acordo com a Análise de Variância, houve variação significativa $(\mathrm{p}<0,01)$ na redução da contagem de E. coli $\mathrm{O} 157: \mathrm{H} 7$ em decorrência da interação tripla entre concentração do ozônio, leite com diferentes composições e período de exposição ao gás (Tabela 7).

Tabela 7. Resumo da análise de variância referente à redução na contagem de Escherichia coli $\mathrm{O} 157: \mathrm{H} 7\left(\log \mathrm{N}_{0} / \mathrm{N}\right)$ em leite com diferentes composições ozonizados nas concentrações de 21 e $31 \mathrm{mg} \mathrm{L}-1$, por períodos de $0,5,15$ e $25 \mathrm{~min}$

\begin{tabular}{lcc}
\hline Fonte de variação & Grau de Liberdade & Quadrado Médio \\
\hline Concentração (C) & 1 & $0,0379^{\mathrm{ns}}$ \\
Substrato (S) & 5 & $28,5922^{* *}$ \\
Tempo (T) & 3 & $10,8131^{* *}$ \\
C x S & 5 & $0,0133^{\mathrm{ns}}$ \\
C x T & 3 & $0,0053^{\mathrm{ns}}$ \\
S x T & 15 & $3,3148^{* *}$ \\
C x S x T & 15 & $0,0029^{* *}$ \\
\hline Tratamentos & 47 & 4,7933 \\
\hline Resíduo & 96 & 0,0099 \\
\hline CV(\%) & & 12,57 \\
\hline
\end{tabular}

Legenda: ** significativo ao nível de $1 \%$ de probabilidade $(\mathrm{p}<0,01)$.

${ }^{\text {ns }}$ não significativo ao nível de $5 \%$ de probabilidade $(\mathrm{p}<0,05)$.

Encontram-se, na Tabela 8 , os valores médios relativos à redução na contagem de $E$. coli $\mathrm{O} 157: \mathrm{H} 7$ em ciclos log, quando se avaliaram diferentes combinações de substratos e períodos de exposição ao ozônio em função da concentração do gás. Não houve aumento significativo $(\mathrm{p}<0,05)$ na redução da contagem de E. coli $\mathrm{O} 157: \mathrm{H} 7$ com o aumento da concentração do ozônio, exceto no substrato LIZL combinado com período de ozonização de 5 min. 
Tabela 8. Valores médios referentes à redução na contagem Escherichia coli O157:H7 (log $\mathrm{N}_{0} / \mathrm{N}$ ) em diferentes combinações de substrato e Período de exposição (P) nas concentrações (C) do ozônio de 21 e $31 \mathrm{mg} / \mathrm{L}$.

\begin{tabular}{ccccccc}
\hline \multirow{2}{*}{ S x P (min) } & \multicolumn{2}{c}{$\mathrm{C}(\mathrm{mg} / \mathrm{L})$} & \multirow{2}{*}{$\mathrm{S} \times \mathrm{P}(\mathrm{min})$} & \multicolumn{2}{c}{$\mathrm{C}(\mathrm{mg} / \mathrm{L})$} \\
\cline { 2 - 3 } \cline { 5 - 6 } & 21 & \multicolumn{2}{c}{31} & & 21 & 31 \\
\hline LINH/5 & $0,24 \pm 0,04 \mathrm{a}$ & $0,26 \pm 0,06 \mathrm{a}$ & $\mathrm{LDZL} / 5$ & $0,66 \pm 0,12 \mathrm{a}$ & $0,78 \pm 0,09 \mathrm{a}$ \\
LINH/15 & $0,38 \pm 0,10 \mathrm{a}$ & $0,41 \pm 0,11 \mathrm{a}$ & LDZL/15 & $0,82 \pm 0,23 \mathrm{a}$ & $0,86 \pm 0,07 \mathrm{a}$ \\
LINH/25 & $0,89 \pm 0,17 \mathrm{a}$ & $0,96 \pm 0,31 \mathrm{a}$ & LDZL/25 & $1,53 \pm 0,34 \mathrm{a}$ & $1,54 \pm 0,23 \mathrm{a}$ \\
LIH/5 & $0,23 \pm 0,02 \mathrm{a}$ & $0,23 \pm 0,04 \mathrm{a}$ & LIZL/5 & $0,27 \pm 0,02 \mathrm{~b}$ & $0,46 \pm 0,09 \mathrm{a}$ \\
LIH/15 & $0,20 \pm 0,04 \mathrm{a}$ & $0,30 \pm 0,05 \mathrm{a}$ & LIZL/15 & $0,44 \pm 0,07 \mathrm{a}$ & $0,56 \pm 0,02 \mathrm{a}$ \\
LIH/25 & $0,29 \pm 0,06 \mathrm{a}$ & $0,38 \pm 0,09 \mathrm{a}$ & LIZL/25 & $0,65 \pm 0,17 \mathrm{a}$ & $0,73 \pm 0,06 \mathrm{a}$ \\
LD/5 & $0,02 \pm 0,07 \mathrm{a}$ & $0,01 \pm 0,01 \mathrm{a}$ & AD/5 & $3,98 \pm 0,01 \mathrm{a}$ & $3,95 \pm 0,04 \mathrm{a}$ \\
LD/15 & $0,03 \pm 0,04 \mathrm{a}$ & $0,03 \pm 0,02 \mathrm{a}$ & AD/15 & $3,98 \pm 0,01 \mathrm{a}$ & $3,94 \pm 0,04 \mathrm{a}$ \\
LD/25 & $0,10 \pm 0,04 \mathrm{a}$ & $0,11 \pm 0,05 \mathrm{a}$ & AD/25 & $3,97 \pm 0,02 \mathrm{a}$ & $3,90 \pm 0,02 \mathrm{a}$ \\
\hline
\end{tabular}

Legenda: Médias seguidas de mesma letra minúscula na linha não diferem estatisticamente pelo Teste de Tukey a 5\% de probabilidade.

LINH - Leite Integral Não Homogeneizado; LIH - Leite Integral Homogeneizado; LD - Leite Desnatado; LDZL - Leite Desnatado Zero Lactose; LIZL - Leite Integral Zero Lactose; AD - Água destilada.

São apresentados, na Tabela 9, os valores médios de reduções em ciclos log na contagem de E. coli O157:H7 para diferentes combinações de concentração do ozônio e períodos de exposição ao gás em leite com diferentes composições. Verificou-se diferença significativa $(\mathrm{p}<0,05)$ em todas as combinações de concentração do ozônio e período de exposição ao gás em função do substrato utilizado. Obtiveram-se maiores reduções na contagem de E. coli O157:H7 quando se utilizaram como substratos água destilada e LDZL, com valores médios entre 3,90 e 3,98 ciclos log e entre 0,66 e 1,54 ciclos log, respectivamente. Nos substratos LIH e LD, as reduções na contagem de E. coli O157:H7 permaneceram inferiores a 0,40 ciclo log em todas as combinações de concentração do ozônio e períodos de exposição ao gás. 
Tabela 9. Valores médios referentes à redução na contagem Escherichia coli O157:H7 (log $\left.\mathrm{N}_{0} / \mathrm{N}\right)$ em diferentes combinações de concentração do gás $(\mathrm{C})$ e Período de exposição $(\mathrm{P})$ em leite com diferentes composições

\begin{tabular}{c|rccccc}
\hline C & \multicolumn{5}{|c}{ Substrato } \\
\cline { 2 - 7 }$(\mathrm{mg} / \mathrm{L}) \times \mathrm{P}(\mathrm{min})$ & LINH & LIH & LD & LDZL & LIZL & AD \\
\hline $21 / 5$ & $0,24 \pm 0,04 \mathrm{~cd}$ & $0,23 \pm 0,02 \mathrm{~cd}$ & $0,02 \pm 0,07 \mathrm{~d}$ & $0,66 \pm 0,12 \mathrm{~b}$ & $0,27 \pm 0,02 \mathrm{c}$ & $3,98 \pm 0,01 \mathrm{a}$ \\
$21 / 15$ & $0,38 \pm 0,10 \mathrm{~cd}$ & $0,20 \pm 0,04 \mathrm{de}$ & $0,03 \pm 0,04 \mathrm{e}$ & $0,82 \pm 0,23 \mathrm{~b}$ & $0,44 \pm 0,07 \mathrm{c}$ & $3,98 \pm 0,01 \mathrm{a}$ \\
$21 / 25$ & $0,89 \pm 0,17 \mathrm{c}$ & $0,29 \pm 0,06 \mathrm{~d}$ & $0,10 \pm 0,04 \mathrm{~d}$ & $1,53 \pm 0,34 \mathrm{~b}$ & $0,65 \pm 0,17 \mathrm{c}$ & $3,97 \pm 0,02 \mathrm{a}$ \\
$31 / 5$ & $0,26 \pm 0,06 \mathrm{c}$ & $0,28 \pm 0,04 \mathrm{c}$ & $0,01 \pm 0,01 \mathrm{~d}$ & $0,78 \pm 0,07 \mathrm{~b}$ & $0,46 \pm 0,09 \mathrm{c}$ & $3,95 \pm 0,04 \mathrm{a}$ \\
$31 / 15$ & $0,41 \pm 0,11 \mathrm{~cd}$ & $0,30 \pm 0,05 \mathrm{~d}$ & $0,03 \pm 0,02 \mathrm{e}$ & $0,86 \pm 0,23 \mathrm{~b}$ & $0,56 \pm 0,02 \mathrm{c}$ & $3,94 \pm 0,04 \mathrm{a}$ \\
$31 / 25$ & $0,96 \pm 0,31 \mathrm{c}$ & $0,38 \pm 0,09 \mathrm{~d}$ & $0,11 \pm 0,05 \mathrm{e}$ & $1,54 \pm 0,09 \mathrm{~b}$ & $0,73 \pm 0,06 \mathrm{c}$ & $3,90 \pm 0,02 \mathrm{a}$ \\
\hline
\end{tabular}

Legenda: Médias seguidas de mesma letra minúscula linha não diferem estatisticamente pelo Teste de Tukey a $5 \%$ de probabilidade.

LINH - Leite Integral Não Homogeneizado; LIH - Leite Integral Homogeneizado; LD - Leite Desnatado; LDZL - Leite Desnatado Zero Lactose; LIZL - Leite Integral Zero Lactose; AD - Água destilada.

Na Figura 5 são apresentadas as curvas de regressão referentes à redução na contagem de E. coli O157:H7 em decorrência da ozonização, em leite com diferentes composições e nas concentrações de 21 e $31 \mathrm{mg} / \mathrm{L}$, em função do período de ozonização. A redução foi mais acentuada à medida que se elevou o período de exposição ao ozônio quando foi utilizada água como substrato. Nos substratos que continham matéria orgânica, esse comportamento foi mais acentuado no substrato LDZL. Apresentam-se na Tabela 10 as equações de regressão ajustadas referentes à redução na contagem de E. coli O157:H7 (log $\mathrm{N}_{0} / \mathrm{N}$ ) em função do período de exposição ao ozônio, em leite com diferentes composições e nas concentrações de 21 e $31 \mathrm{mg} / \mathrm{L}$, e seus respectivos coeficientes de determinação.
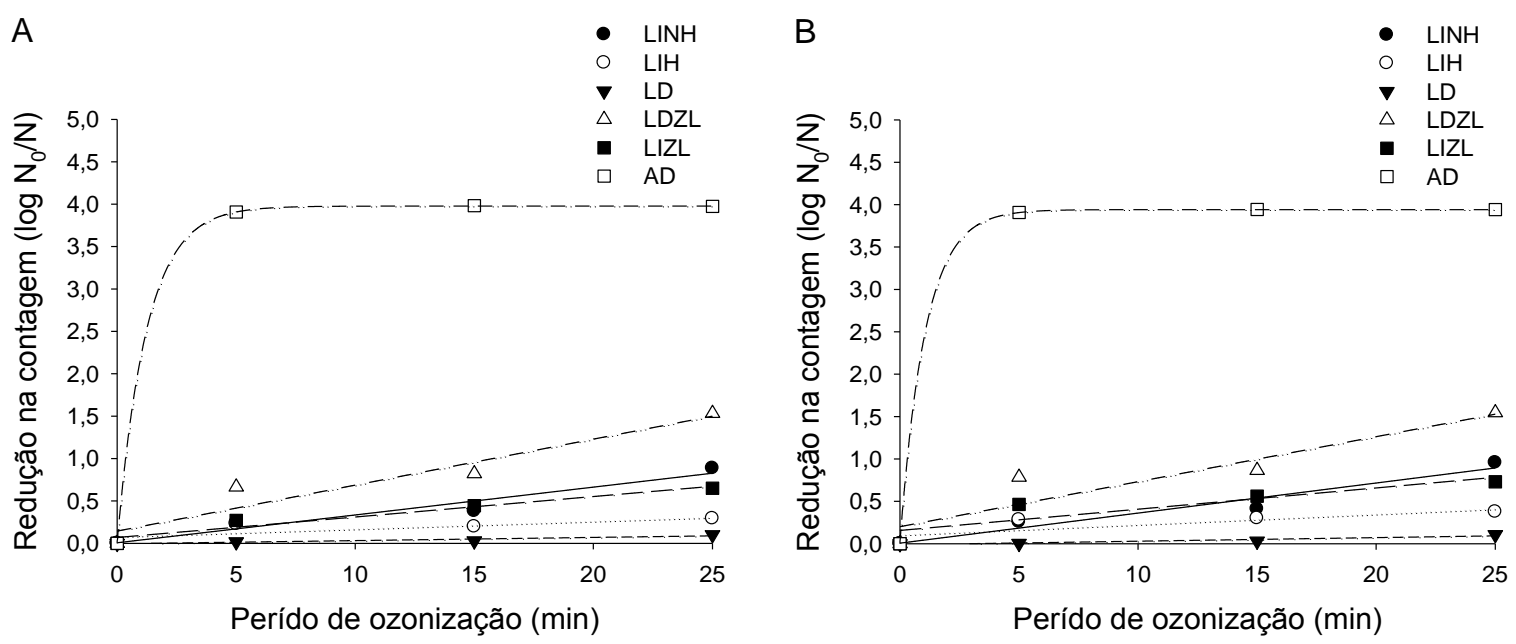
Figura 5. Redução na contagem de Escherichia coli O157:H7 $\left(\log \mathrm{N}_{0} / \mathrm{N}\right)$ em diferentes substratos nas concentrações de $21 \mathrm{mg} / \mathrm{L}$ (A) e $31 \mathrm{mg} / \mathrm{L}$ (B) em função do período de exposição ao ozônio.

Legenda: LINH - Leite Integral Não Homogeneizado; LIH - Leite Integral Homogeneizado; LD Leite Desnatado; LDZL - Leite Desnatado Zero Lactose; LIZL - Leite Integral Zero Lactose; AD Água destilada.

Tabela 10. Equações de regressão ajustadas da redução na contagem de Escherichia coli O157:H7 $\left(\log \mathrm{N}_{0} / \mathrm{N}\right)$ em função do período de exposição ao ozônio, em leite com diferentes composições nas concentrações de 21 e $31 \mathrm{mg} / \mathrm{L}$, e seus respectivos coeficientes de determinação

\begin{tabular}{|c|c|c|c|}
\hline $\begin{array}{c}\text { Concentração do } \\
\text { ozônio (mg/L) }\end{array}$ & Substrato & Equações ajustadas & $\mathbf{R}^{2}$ \\
\hline \multirow{6}{*}{21} & LINH & $\widehat{\mathrm{y}}=0,007+0,03 \mathrm{z}$ & 0,95 \\
\hline & LIH & $\widehat{y}=0,077+0,009 x$ & 0,64 \\
\hline & $\mathrm{LD}$ & $\widehat{y}=0,005+0,004 x$ & 0,88 \\
\hline & LDZL & $\widehat{y}=0,144+0,054 x$ & 0,91 \\
\hline & LIZL & $\widehat{y}=0,069+0,024 x$ & 0,95 \\
\hline & $\mathrm{AD}$ & $\hat{y}=3,978\left(1-e^{(-0,808 x)}\right)$ & 0,99 \\
\hline \multirow{6}{*}{31} & LINH & $\widehat{y}=0,007+0,036 x$ & 0,95 \\
\hline & LIH & $\widehat{y}=0,102+0,012 x$ & 0,68 \\
\hline & $\mathrm{LD}$ & $\widehat{y}=-0,012+0,004 x$ & 0,89 \\
\hline & LDZL & $\widehat{y}=0,201+0,053 x$ & 0,87 \\
\hline & LIZL & $\widehat{y}=0,157+0,025 x$ & 0,79 \\
\hline & $\mathrm{AD}$ & $\hat{y}=3,941\left(1-e^{(-0,945 x)}\right)$ & 0,99 \\
\hline
\end{tabular}

Legenda: LINH - Leite Integral Não Homogeneizado; LIH - Leite Integral Homogeneizado; LD Leite Desnatado; LDZL - Leite Desnatado Zero Lactose; LIZL - Leite Integral Zero Lactose; AD Água destilada.

É importante ressaltar que quando o substrato ozonizado foi água, independentemente da concentração do ozônio, obteve-se máxima redução detectável na contagem de E. coli $\mathrm{O} 157: \mathrm{H} 7$, com 5 min de exposição gás, tendo em vista o inóculo inicial. 
Na Tabela 11, encontram-se os valores relativos à concentração do ozônio dissolvido na água armazenada na temperatura de $8^{\circ} \mathrm{C}$ por até 24 h. São apresentados também a temperatura da água no momento de cada medição da concentração do ozônio. A concentração do ozônio residual permaneceu na faixa entre 1,97 e 0,82 mg/L durante o período de armazenamento da água ozonizada na temperatura de $8^{\circ} \mathrm{C}$. Ressalta-se que houve variação da temperatura da água ozonizada durante o armazenamento. Tal variação pode ser justificada pelo fato de que a ozonização da água foi realizada em ambiente com temperatura em torno de $20^{\circ} \mathrm{C}$. Dessa forma, durante esse processo ocorreu aumento da temperatura da água para $14^{\circ} \mathrm{C}$. Salienta-se que a temperatura da água antes da ozonização era de $8^{\circ} \mathrm{C}$.

Tabela 11. Valores médios de concentração do ozônio dissolvido e da temperatura em água armazenada a $8^{\circ} \mathrm{C}$, por 24 horas.

\begin{tabular}{ccccccc}
\hline \multirow{2}{*}{ Variáveis } & \multicolumn{6}{c}{ Período de armazenamento da água ozonizada (h) } \\
\cline { 2 - 7 } & 0 & 0,5 & 1,0 & 1,5 & 3,0 & 24 \\
\hline Concentração $(\mathrm{mg} / \mathrm{L})$ & 1,45 & 1,97 & 1,71 & 1,78 & 1,67 & 0,82 \\
Temperatura $\left({ }^{\circ} \mathrm{C}\right)$ & 14 & 12,0 & 11,0 & 11,0 & 9,5 & 8,0 \\
\hline
\end{tabular}

No que se refere à eficácia da água ozonizada na inativação de $E$. coli O157:H7, por período de exposição de 5 min, verificou-se redução de aproximadamente 4,50 ciclos log. Esse resultado foi obtido para todos os períodos de armazenamento da água ozonizada na temperatura de $8^{\circ} \mathrm{C} \pm 1$, com concentrações de ozônio dissolvido na faixa entre 0,82 e 1,97 mg/L (Tabela 11). Ressalta-se que a redução na contagem de E. coli O157:H7 de 4,50 ciclos log foi a máxima possível de ser obtida, levando-se em consideração o inóculo inicial. 


\section{DISCUSSÃO}

O ozônio gasoso foi capaz de reduzir a contagem de E. coli O157:H7. Todavia a redução na contagem dos microrganismos foi menor nos substratos que continham matéria orgânica, nas diferentes combinações de concentração do gás e período de exposição. Enquanto que em água destilada (AD), foi possível obter reduções superiores a 3,9 ciclos log, em todas as combinações de concentração do gás e período de exposição, nos substratos LIH e $\mathrm{LD}$, as reduções permaneceram inferiores a 0,4 ciclo log.

Podem ser encontrados na literatura diversos trabalhos nos quais se avalia a eficácia do ozônio gasoso como agente para controle de microrganismos. O ozônio possui amplo espectro antimicrobiano (KHADRE et al., 2001) e cada espécie de microrganismo possui sensibilidade inerente ao gás (CULLEN et al., 2009). A ozonização tem sido testada no controle de fungos, bactérias Gram negativas e Gram positivas e vírus (RESTAINO et al., 1995; TANAKA et al., 2009; ZOTTI et al., 2009; SUNG et al., 2014; SANCHEZ et al., 2016).

A inativação de microrganismos pelo ozônio é um processo complexo que ocorre devido à ruptura do envoltório celular e posterior dispersão dos constituintes citoplasmáticos, uma vez que esse gás apresenta elevado potencial oxidativo (CULLEN et al., 2009). O ozônio é capaz de reagir com diversos constituintes celulares, tais como proteínas, ácidos graxos insaturados, peptideoglicanos da parede celular, enzimas e ácidos nucléicos (KHADRE et al., 2001). Em meio aquoso, a inativação dos microrganismos é atribuída ao ozônio molecular e aos radicais hidroxila, hidroperoxila e superóxido, gerados a partir da sua decomposição, segundo MANOUSARIDIS (et al., 2005). Todavia, ainda não foi elucidado qual mecanismo é o mais determinante (CULLEN et al., 2009).

Dentre os fatores que afetam a ação do ozônio sobre os microrganismos, destacam-se o pH, temperatura e a composição do meio. Em se tratando de meio rico em compostos orgânicos, têm-se que essas substâncias podem competir com os microrganismos pelo ozônio (KHADRE et al., 2001). Isso justifica a maior eficácia na inativação dos 
microrganismos pelo ozônio nos substratos menos ricos em matéria orgânica. Nos substratos orgânicos, a maior eficácia na inativação de E. coli O157:H7 foi obtida no substrato LDZL, caracterizado por possuir reduzidos teores de gordura e lactose. Nesse substrato, as máximas reduções na contagem de E. coli O157:H7 foram de 1,53 e 1,54 ciclos log, quando se adotaram as concentrações de 21 e $31 \mathrm{mg} / \mathrm{L}$, por $25 \mathrm{~min}$. Esses resultados estão de acordo com os obtidos por RESTAINO et al. (1995), que avaliaram a eficácia do ozônio na inativação de bactérias Gram positivas e Gram negativas, leveduras e fungos em água contendo ou não amido e albumina do soro bovino. Os autores observaram efeito significativo da presença de matéria orgânica na inativação dos microrganismos. GUZEL-SEYDIM et al. (2004), estudaram o efeito da presença de gordura, proteínas e carboidratos na inativação de Bacillus stearothermophilus, E. coli e S. aureus pelo ozônio. Os constituintes que promoveram maior efeito de proteção nos microrganismos forma creme de leite e caseínato.

Resultados semelhantes foram obtidos por CHOI et al. (2012), em suco de maçã com diferentes teores de sólidos solúveis. O ozônio foi capaz de inativar E. coli O157:H7, Salmonella typhimurium e Listeria monocytogenes, mas a eficácia da ozonização foi dependente do teor de sólidos solúveis no suco de maçã.

Outro fator que deve ser mencionado e que afeta a eficácia do ozônio sobre microrganismos é o efeito da presença de compostos orgânicos na decomposição do gás. O ozônio se destaca por ser instável tanto na fase gasosa quanto dissolvido em água (MANOUSARIDIS et al., 2005). Em água destilada, a meia vida do ozônio a $20^{\circ} \mathrm{C}$ permanece na faixa entre 20 e 30 min (KHADRE et al., 2001). Em meios mais ricos em matéria orgânica, é esperada decomposição mais rápida do ozônio e consequentemente menor eficácia na inativação dos microrganismos. BELTRÁN (2005), afirma que em meio aquoso contendo matéria orgânica, incialmente há rápido consumo do ozônio. À medida que ocorre degradação dos compostos orgânicos, a decomposição do ozônio se torna mais lenta. Nesse contexto, no presente trabalho, a rápida decomposição do ozônio nos substratos mais ricos em matéria orgânica justifica a menor eficácia do gás na inativação dos microrganismos.

É importante destacar a diferença significativa observada na inativação de $E$. coli O157:H7 quando se comparou o efeito do ozônio nos substratos LINH e LIH, nas concentrações de 21 e $31 \mathrm{mg} / \mathrm{L}$ e $25 \mathrm{~min}$ de período de exposição. No substrato LINH, obtiveram-se reduções equivalentes a 0,86 e 0,96 ciclo log, para concentrações de 21 e 31 $\mathrm{mg} / \mathrm{L}$, respectivamente, enquanto que no substrato $\mathrm{LIH}$, as reduções foram de 0,29 e 0,39 ciclo log, para concentrações de 21 e $31 \mathrm{mg} / \mathrm{L}$, respectivamente. Tais diferenças podem ser atribuídas à diferença no tamanho dos glóbulos de gordura nos substratos. O substrato LIH 
equivale a leite que passou previamente por processo de homogeneização, o que acarreta na redução do tamanho dos glóbulos de gordura e consequentemente aumento da área superficial (BERTON et al., 2012). O substrato LINH não passou por processo de homogeneização, apresentando dessa forma maiores glóbulos de gordura. A gordura de leite é sintetizada como glóbulos de 0,1 a $15 \mu \mathrm{m}$ por células da glândula mamária (GRAVES et al., 2007). Então, é possível inferir que maior área superficial dos glóbulos de gordura no substrato LIH ocasionou degradação mais acelerada do ozônio, o que justifica a menor eficácia do gás na inativação de E. coli O157:H7.

Ressalta-se que a ozonização não afetou as características físico-químicas dos substratos avaliados nas concentrações de 21 e $31 \mathrm{mg} / \mathrm{L}$ por até $25 \mathrm{~min}$. Esses resultados estão de acordo com os obtidos por SANTOS (2013), que não observou alterações significativas nos parâmetros do leite cru ozonizado na concentração de $3 \mathrm{mg} / \mathrm{L}$ por até $1,5 \mathrm{~min}$.

Com relação à ação da água destilada ozonizada no controle de E. coli O157:H7, ressalta-se a elevada eficácia na inativação do microrganismo, mesmo depois de estocagem por $24 \mathrm{~h}$, na temperatura de $8^{\circ} \mathrm{C} \pm 1$. Resultados semelhantes foram obtidos no presente trabalho quando se aplicou diretamente o ozônio em água destilada, nas concentrações de 21 e $31 \mathrm{mg} / \mathrm{L}$, e período de exposição de 5,0 min.

Diversos autores avaliaram a eficácia da água ozonizada de microrganismos importantes deteriorantes e patogênicos de importância na indústria de alimentos, sendo obtidos resultados semelhantes ao do presente trabalho. MARI et al. (2003) observaram em seu estudo com peras, que a germinação de esporos dos fungos deteriorantes Penicillium expansum, Botrytis cinérea e Mucor piriformis foi inibido pelo tratamento com água ozonizada na concentração de 0,99 a $0,4 \mathrm{mg} / \mathrm{L}$ (ozônio dissolvido na água) durante $5 \mathrm{~min}$, na temperatura de $20^{\circ} \mathrm{C}$. BELTRAN et al. (2005), avaliaram o efeito da água ozonizada na manutenção da qualidade de alface e indicaram que o ozônio pode ser uma alternativa ao cloro para conservação do produto. INATSU et al., (2011) testaram água ozonizada como agente antimicrobiano no controle in vitro de várias espécies de bactérias, dentre as quais $E$. coli O157:H7, S. aureus, L. monocytogenes e Pseudomonas aeruginosa. Os autores obtiveram redução de 7,4 ciclos log na contagem de E. coli $\mathrm{O} 157: \mathrm{H} 7$, para tempo de exposição de 3,0 min e concentração do ozônio dissolvido na água de $5,44 \mathrm{mg} / \mathrm{L}$, na temperatura de $25^{\circ} \mathrm{C}$. CAVALCANTE et al. (2014), testaram água ozonizada no controle de E. coli O157:H7 e B. subtilis e observaram reduções de 6,6 e 5,3 ciclos log, respectivamente, quando se adotou a concentração de ozônio de 1,0 mg/L e 1,0 min de contato. Pesquisa na qual se testou a água ozonizada, com concentração de ozônio dissolvido entre 0,9 e 3,2 mg/L e tempo de contato 
entre 1 e 20 min, para a desinfecção e remoção de biofilme de $P$. fluorescence e $P$. aeruginosa foi realizada por TACHIKAWA et al. (2009). A taxa de sobrevivência de biofilmes de $P$. fluorescence foi de 1,0\%, para concentração de ozônio na água entre 0,9 e 1,4 mg/L e período de exposição de 5 min. Quando se elevou a concentração de ozônio dissolvido na água para $3,2 \mathrm{mg} / \mathrm{L}$, a taxa de sobrevivência foi de 0,01 e $0,00002 \%$, para período de exposição de 5 e 20 min. 


\section{CONCLUSÃO}

A aplicação do gás ozônio não altera os principais componentes do leite.

A aplicação direta e indireta de ozônio reduz as contagens de Escherichia coli O157:H7 (ATCC® 43890M) comprovando a sua eficiência.

A eficácia da água ozonizada foi confirmada com obtenção de máxima redução.

O ozônio representa uma alternativa eficaz aos sanitizantes tradicionais. 


\section{REFERÊNCIAS}

BELTRÁN, F.J. Ozone reaction kinetics for water and wastewater systems. Boca Raton: CRC Press, 358p, 2005.

BELTRÁN, D.; SELMA, M. V.; MARÍN, A.; GIL, M. I. Ozonated water extends the shelf life of fresh-cut lettuce. Journal of Agricultural and Food Chemistry, v. 53, n. 14, p. 5654-5663, 2005.

BERTON, A.; ROUVELlAC, S.; ROBERT, B.; ROUSSEAU, F.; LOPEZ, C.; CRENON, I. Effect of the size and interface composition of milk fat globules on their in vitro digestion by the human pancreatic lipase: native versus homogenized milk fat globules. Food Hydrocolloids, v. 29, n.1, p. 123-134, 2012.

BEUTIN, L.; KRAUSE, G.; ZIMMERMANN, S.; KAULFUSS, S.; GLEIER, K. Characterization of Shiga toxin-producing Escherichia coli strains isolated from human patients in Germany over a 3-year period. Journal of Clinical Microbiology, v. 42, n. 3, p. $1099-1108,2004$.

BLANCO, M.; BLANCO, J. E.; MORA, A.; REY, J.; ALONSO, J. M.; HERMOSO, M.; HERMOSO, J.; ALONSO, M. P.; DAHBI, G.; GONZÁLEZ, E. A.; BERNADÉZ, M. I.; and BLANCO, J. Serotypes, virulence genes, and intimin types of Shiga toxin (verotoxin)-producing Escherichia coli isolates from healthy sheep in Spain. Journal of Clinical Microbiology, v. 41, n. 4, p. 1351-1356, 2003.

BOSILEVAC, J. M. and KOOHMARAIE, M. Prevalence and characterization of non-O157 Shiga toxin-producing Escherichia coli isolates from commercial ground beef in the United States. Applied and Environment Microbiology, v. 77, n. 6, p. 2103-2112, 2011.

BRENNER, D. J.; FRAMER III, J. J. Enterobacteriacea. In: BRENENER, D. J.; KRIEG, N. R.; STALEY, J. T. (Eds.) Bergey's Manual of Sistematic Bacteriology. 2 ed. v. 2 New York: Spring Scienc+Business Media Inc, p. 587-607, 2005. 
BROWN, C. Emerging zoonoses and pathogens of public health significance: an overview. Revue scientifique et technique-office international des epizooties, v.23, n.2, p. 43542, 2004.

CAMPOS, L.C.; TRABULSI, L.R. Escherichia. In.: TRABULSI, L.R. et al. Microbiologia. 3 ed. São Paulo : Atheneu, 2002, p. 215-228, 2002.

CAPALONGA, R., RAMOS, R. C., BOTH, J.M.C., SOEIRO, M. L. T., LONGARAY, S. M.; HAAS, S. et al. Salmonella serotypes, resistance patterns, and food vehicles of salmonellosis in southern Brazil between 2007 and 2012. The Journal of Infection in Developing Countries, v. 8, n. 7,p. 811-7, 2014.

CAVAlCANTE, M. A.; LEITE JUNIOR, B. R. C.; TRIBST, A. A. L.; CRISTIANINI. Sanitização de alface americana com água ozonizada para inativação de Escherichia coli O157:H7. Segurança Alimentar e Nutricional. v. 21, n.1, p. 373-38, 2014a. Uso de ozônio gasoso na sanitização de câmaras frigoríficas. Revista do Instituto de Laticínios Cândido Tostes, v. 69, n. 2, p. 121-18. 2014 b. Inactivation of Escherichia Coli O157: H7 and Bacillus Subtilis by Ozonated Water. Centro de Perquisa e Processamento de Alimentos, 2014, v. 32, n.1, p. $105-112,2014 \mathrm{c}$.

CAVALCANTE, D. A. et al. Shelf life evaluation of the iceberg lettuce sanitized with ozone water. Ciência Rural, v. 45, n. 11, p. 2089-2096, 2015.

CENTERS FOR DISEASE CONTROL AND PREVENTION. Multistate outbreak of Shiga toxin-producing Escherichia coli $\mathrm{O} 157: \mathrm{H} 7$ infections linked to ground beef (final update). 2014 [acesso em: 20 dezembro de 2015]. Disponível em: http://www.cdc.gov/ecoli/2014/O157H7-05-14/index.html.

CHERNAKI-LEFFER, A. M.; BIESDORF, S. M.; ALMEIDA, L. M.; LEFFER, E. V. B; VIGNE, F. Isolamento de enterobactérias em Alphitobius diaperinus e na cama de aviários no oeste do estado do Paraná, Revista Brasileira de Ciência Avícola, vol. 4, n. 3, p. 243-247, 2002.

CHEMAT, F., and KHAN, M. K. Applications of ultrasound in food technology: Processing, preservation and extraction. Ultrasonic Sonochemistry, v. 18, n. 4, p. 813-835, 2011.

CHEN, Z; ZHU, C. Combined effects of aqueous chlorine dioxide and ultrasonic treatments on postharvest storage quality of plum fruit (Prunus salicinaL.). Postharvest Biology and Technology, v. 61, n. 2-3, p. 117-123, 2011. 
CHEN, Y.; WANG, H.; XU, Y.; WU, J.; XIAO, G. Effect of treatment with dimethyl dicarbonate on microorganisms and quality of Chinese cabbage.Postharvest Biology and Technology, v. 76, p. 139-144, 2013.

CHOI, M. R.; LIU, Q.; LEE, S. Y.; JIN, J. H.; RYU, S.; KANG, D. H. Inactivation of Escherichia coli O157: H7, Salmonella typhimurium and Listeria monocytogenes in apple juice with gaseous ozone. Food microbiology, v. 32, n. 1, p. 191-195, 2012.

CLESCERI, L.S.; GREENBERG, A.E. EATON, A.D. Standard methods for the examination of water and wastewater. Denver: American Water Works Association, p. 1220, 2000.

CONRAD, C. C.; STANFORD, K.; MCALliSTER, T. A.; THOMAS, J.; REUTER, T. Further development of sample preparation and detection methods for $\mathrm{O} 157$ and the top 6 non-O157 STEC serogroups in cattle feces. Journal Microbiology Methods. 2014;105:22-30. http://dx.doi.org/10.1016/j.mimet.2014.06.020;

COUTO, E. P.; ALENCAR, E. R.; GONÇALVES, V. S. P., dos SANTOS, A. J. P., RIBEIRO, J. L., FERREIRA, M. Efeito da ozonização sobre a contagem da Staphylococcus aureus inoculado em leite. Semina: Ciências Agrárias, v. 37, n. 4, p. 1911-1918, 2016.

CULlEN, P. J.; TIWARI, B. K; O’DONNELL, C. P.; MUTHUKUMARAPPAN, K. Modelling approaches to ozone processing of liquid foods. Trends in Food Science \& Technology, Amsterdam, v. 20, p. 125-136, 2009.

EUROPEAN FOOD SAFETY AUTHORITY. The European Union summary report on trends and sources of zoonoses, zoonotic agents and food-borne outbreaks in the European Union in 2010. EFSA JOURNAL; 2012; 10:2597. http://dx.doi.org/10.2903/j.efsa.2012.2597.

FENG, P.; WEAGANT, S. D.; JINNEMAN, K. Diarrheagenic Escherichia coli. 2011 [Acesso em: jun 2014]. Disponível em: http://www.fda.gov/Food/FoodScienceResearch/ aboratoryMethods/ucm070080.htm.

FORSYTHE, S. J. Microbiologia da Segurança dos Alimentos United Kingdon, WileyBlackwell, $2^{\circ}$ ed., p.496, 2013.

GUZEL-SEYDIM, Z.; BEVER, P. I.; GREENE, A. K. Efficacy of ozone to reduce bacterial populations in the presence of food components. Food Microbiology, Clemson, v. 21, n. 4, p. 475-479, 2004.

GRAVES, E. L. F.; BEAUlIEU, A. D.; DRACKLEY, J. K. Factors affecting the concentration of sphingomyelin in bovine milk. Journal of Dairy Science, v. 90, p. 706715, 2007. 
INATSU, Y.; KITAGAWA, T.; NAKAMURA, N.; KAWASAKI, S.; NEI, D.; BARI, M. L.; KAWAMOTO, S. Effectiveness of stable ozone microbubble water on reducing bacteria on the surface of selected leafy vegetables. Food Science and Technology Research, v. 17, n. 6, p. 479-485, 2011.

JAY, J. M. Microbiologia de alimentos. 6. Ed. Porto Alegre: Artmed, 711p, 2005.

KHADRE, M.A.; YOUSEF, A.E.; KIM, J.G. Microbiological Aspects of Ozone Applications in Food: A Review. Journal of Food Science, v. 66, n. 9, p. 1242-1252, 2001.

KUHNERT, P.; BOERLIN, P.; FREY, J. Target genes for virulence assessment of Escherichia coli isolates from water, food and the environment. FEMS Microbiology reviews, v. 24, n. 1, p. 107-117, 2000.

KIM, J. G.; YOUSEF, A. E.; CHISM, G. W. Use of ozone to inactivate microorganisms on lettuce. Journal of Food Safety, v.19, p.17-37, 1999.

KIM, J. G.; YOUSEF, A. E.; DAVE, S. Application of ozone for enhancing the microbiological safety and quality of foods: a review. Journal of Food Protection, v. 62, n. 9, p.1071-1087, 1999.

LIU, Y.; GILL, A.; MCMULLEN, L.; GANZLE, M. G. Variation in heat and pressure resistance of verotoxigenic and nontoxigenic Escherichia coli. Journal of Food Protection, v. 78, n. 1, p. 111-120, 2015.

LUND, B. M.; O'BRIEN, S. J. Microbiological safety of food in hospitals and other healthcare settings. Journal of Hospital Infection, v. 73, n. 2, p. 109-20, 2009.

MACEDO, J. A. B. Águas e águas. Belo Horizonte: Conselho Regional de Química, p. 977, 2004.

MACHADO, T. F. Patógenos emergentes em alimentos. Fortaleza: Embrapa Agroindústria Tropical; 2013.

MANOUSARIDIS, G.; NERANTZAKI, A.; PALEOLOGOS, E. K.; TSIOTSIAS, A.; SAVVAIDIS, I. N.; KONTOMINAS, M. G. Effect of ozone on microbial, chemical and sensory attributes of shucked mussels. Food Microbiology, v. 22, n.1, p. 1-9, 2005.

MARI, M.; BRETOLLINI, P.; PRATELLA, G. C.; Conventional methods for the controlo of post-harvest pear diseases. Journal of Applied Microbiology, New York, v. 94, p. 761$766,2003$.

MENG, J.; DOYLE, M. P. Microbiology of shiga toxin-producing Escherichia coli in foods. In: KAPER, J. B., O'BRIEN, A. D. (Eds). Escherichia coli O157:H7 and other Shiga toxin-producing E. coli strains. Washington DC: ASM Press, p. 98, 1998. 
NASCIMENTO, M. S.; SILVA, N.; CATANOZI, M. P. L. M.; SILVA, K. C. Effect of different disinfection treatments on the natural microbiota of lettuce. Journal of Food Protection, Des Moines, v. 66, p. 1697-1700, 2003.

NATARO, J. P.; KARPER, J. B. Diarrheagenic Escherichia coli. Clinical Microbiology Reviews, v. 11, n. 1, p. 142-201, 1998.

PAULA, C. M. D.; LOIKO, M. R.; TONDO, E. C. Escherichia coli O157:H7 local epidemiology and disease spectrum in Brazil. Clinical and Biomedical Research, v. 34, n. 2, p.113-21, 2014.

PIANCIOLA, L.; CHINEN, I.; MAZZEO, M.; MILIWEBSKY, E.; GONZÁLEZ, G.; MULLER, C.; et al. Genotypic characterization of Escherichia coli O157:H7 strains that cause diarrheaand hemolytic uremic syndrome in Neuquén, Argentina. International Journal Medical Microbiology, v. 304, n. 3-4, p. 499-504, 2014.

RESTAINO, L.; FRAMPTON, E.; HEMPHILL, J.; PALNIKAR, P. Efficacy of ozonated water against various food-related microorganisms. Applied Environmental Microbiology, v. 61, p. 3471-3475, 1995.

ROCHA, S. L. S. Detecção de fatores de virulência de amostras de Escherichia coli isoladas de granjas avicolas do RS através do Multiplex-PCR. (Dissertação) Mestrado, p. 68. Universidade do Rio Grande do Sul, 2008.

SANCHEZ, B. A. O.; ALENCAR, E. R.; PINELI, L. L. O.; FERREIRA, W. F. S.; ROBERTO, M. A. Tracing interactions among column height, exposure time and gas concentration to dimension peanut antifungal ozonation., LWT - Food Science and Technology Zurich, v. 65, p. 668-675, 2016.

SANTOS, A. J. P. Avaliação da utilização de ozônio como método de beneficiamento de leite. (Monografia) - Universidade de Brasília, p. 46, 2013.

SELMA, M.V.; IBANEZA, A. M.; ALLENDE, A.; CANTWELLA, M.; SUSLOW, T. Effect of gaseous ozone and hot water on microbial and sensory quality of cantaloupe and potential transference of Escherichia coli O157:H7 during cutting. Food Microbiology, v. 25, n.1, p.162-168, 2008.

SHEELAMARY, M. and MUTHUKUMAR, M. Effectiveness of Ozone in Inactivating Listeria monocytogenes from Milk Samples. World Journal Young Researchers, v. 1, n. 3, 40, 2011.

SHEN, C; LUO, Y.; NAN, X.; BAUCHAN, G.; ZHOU, B.; WANG, Q.; MILNER, P. Enhanced inactivation of Salmonella and Pseudonomas biofilms on stainless steel by use 
of T-128, a fresh produce washing aid in chlorinated wash solution. Applied Environmental Microbiology, v.78, n.19, p. 6789-98, 2012.

SUNG, H. J.; SONG, W. J; KIM, K. P.; RYU, S.; KANG, D. H. Combination effect of ozone and heat treatments for the inactivation of Escherichia coli O157: H7, Salmonella Typhimurium, and Listeria monocytogenes in apple juice. International Journal of Food Microbiology, v. 171, p. 147-153, 2014.

TANAKA, H.; SAKURAI, M.; ISHII, K.; and MATSUZAWA, Y. Inactivation of influenza virus by ozone gas. IHI Engr Rev, v. 42, p. 108-11, 2009.

TACHIKAWA, M.; YAMANAKA, K.; NAKAMURO, K. Studies on the disinfection and removal of biofilms by ozone water using an artificial microbial biofilm system. Ozone: Science \& Engineering, v, 31, n. 1, p. 3-9, 2009.

TONDO, E.C.; RITTER, A. C. Salmonella and Salmonellosis in Southern Brazil: a review of the last decade. In: MONTE, A. S.; SANTOS, P. E.; organizators. Salmonella: classification, genetics and disease outbreaks. Nova York: Nova; p. 175-91, 2012.

TORTORA, G. J.; FUNK, B.R.; CASE, C. L. Doenças Bacterianas do Sistema Digestivo Inferior. In: TORTORA, G. J.; FUNK, B. R.; CASE, C. L. Microbiologia. $6^{\circ}$ ed. Porto Alegre, Artmed; p. 669-70, 2000.

WORLD HEALTH ORAGANIZATION. WHO global strategy for food safety: safer food for better health. Geneva: World Health Organization, 2002.

ZOTTI, M.; PORRO, R.; VIZZINI, A.; MARIOTTI, M.G. Inactivation of Aspergillus spp. by ozone treatment. Ozone-Science \& Engineering, v. 30, n. 6, p. 423-430, 2008. 


\section{CONSIDERAÇÕES FINAIS}

A indústria do setor alimentício necessita cada vez mais de recursos para incrementar a tecnologia de processamento dos produtos, a fim de atender a demanda dos consumidores, requerendo padrões cada vez mais rigorosos de higiene e segurança alimentar. Do ponto de vista higiênico sanitário e econômico, há uma preocupação cada vez maior da indústria em estender o tempo de prateleira dos alimentos, mas para isso é necessário a implantação de inovações tecnológicas nos processos de limpeza e sanitização.

Foi possivel demonstrar que a ozonização pode ser empregada no processamento de alimentos como uma alternativa ambientalmente adequada aos sanitizantes químicos, no controle de microrganismos deteriorantes e patogênicos, sem prejuízo das atividades metabólicas de microrganismos benéficos como as bactérias ácido láticas.

Os dados gerados reafirmam o potencial antimicrobiano do ozônio e ampliam o horizonte de futuras e necessárias, pesquisas visando a sua utilização em todas as etapas de produção de alimentos.

Na produção de leite e derivados, de forma mais específica, a partir de estudos já realizados pelo grupo de pesquisa vislumbra-se pesquisar a utilização do ozônio em sistemas de ordenha de várias espécies, a fim de contribuir com a melhoria da qualidade do leite produzido na região; a utilização do ozônio na fabricação de derivados do leite, em especial, nos processos de higienização de plantas de processamento e controle da qualidade do ar em câmaras de maturação e de estocagem, por exemplo.

Acreditamos que ainda é necessário avaliar a ação do ozônio sobre os diversos microrganismos que podem estar presentes em alimentos incluindo os benéficos, de forma a avaliar a ação do gás sobre os seus metabolismos; assim como estudar a influência de outros componentes, inclusive de origem vegetal que possam estar presentes nos substratos ou em equipamentos de processamento de alimentos; ainda, buscar avaliar a eficiência na diminuição ou eliminação, de biofilmes em plantas de processamento de alimentos em diversas superfícies tais como, aço inoxidavel, vidro, plástico, e madeira. 
Por fim, consideramos que esse e futuros estudos poderão contribuir para a melhoria da qualidade dos processos de produção de alimentos e consequentemente, com a saúde dos consumidores. 


\section{ANEXOS}

Tabela 1A. Valores médios referentes ao teor de lactose e de teor de proteínas em leite com diferentes composições (S) submetidos a ozonização em diferentes de concentração e período de exposição $(\mathrm{P})$

\begin{tabular}{|c|c|c|c|c|c|c|c|c|c|c|c|}
\hline \multicolumn{6}{|c|}{ Teor de lactose $(\%)$} & \multicolumn{6}{|c|}{ Teor de proteínas (\%) } \\
\hline \multirow{2}{*}{$\begin{array}{l}S \times P \\
(\min )\end{array}$} & \multicolumn{2}{|c|}{ Concentração (mg/L) } & \multirow[t]{2}{*}{$\mathrm{S} \times \mathrm{P}(\min )$} & \multicolumn{2}{|c|}{ Concentração (mg/L) } & \multirow{2}{*}{$\begin{array}{l}\mathrm{S} \times \mathrm{P} \\
(\mathrm{min})\end{array}$} & \multicolumn{2}{|c|}{ Concentração (mg/L) } & \multirow[t]{2}{*}{$\mathrm{S} \times \mathrm{P}(\min )$} & \multicolumn{2}{|c|}{$\begin{array}{c}\text { Concentração } \\
(\mathrm{mg} / \mathrm{L})\end{array}$} \\
\hline & 21 & 31 & & 21 & 31 & & 21 & 31 & & 21 & 31 \\
\hline LINH/0 & $5,21 \pm 0,02 \mathrm{Aa}$ & $5,21 \pm 0,02 \mathrm{Aa}$ & LDZL/0 & $0,00 \pm 0,00$ & $0,00 \pm 0,00$ & LINH/0 & $3,08 \pm 0,01 \mathrm{Aa}$ & $3,08 \pm 0,08 \mathrm{~A}$ & LDZL/0 & $5,10 \pm 0,15$ & $5,10 \pm 0,15$ \\
\hline LINH/5 & $5,41 \pm 0,01 \mathrm{Aa}$ & $5,31 \pm 0,07 \mathrm{Aa}$ & LDZL/5 & $0,00 \pm 0,00$ & $0,00 \pm 0,00$ & LINH/5 & $3,11 \pm 0,01 \mathrm{Aa}$ & $3,11 \pm 0,02 \mathrm{Aa}$ & LDZL/5 & $5,25 \pm 0,52$ & $5,33 \pm 0,64$ \\
\hline LINH/15 & $5,39 \pm 0,08 \mathrm{Aa}$ & $5,07 \pm 0,18 \mathrm{Ab}$ & LDZL/15 & $0,00 \pm 0,00$ & $0,00 \pm 0,00$ & LINH/15 & $3,09 \pm 0,05 \mathrm{Aa}$ & $2,88 \pm 0,13 \mathrm{Bb}$ & LDZL/15 & $5,20 \pm 0,37$ & $5,08 \pm 0,40$ \\
\hline LINH/25 & $5,39 \pm 0,02 \mathrm{Aa}$ & $4,46 \pm 0,39 \mathrm{Bb}$ & LDZL/25 & $0,00 \pm 0,00$ & $0,00 \pm 0,00$ & LINH/25 & $3,12 \pm 0,03 \mathrm{Aa}$ & $2,66 \pm 0,17 \mathrm{Cb}$ & LDZL/25 & $4,94 \pm 0,36$ & $5,02 \pm 0,31$ \\
\hline $\mathrm{LIH} / 0$ & $4,93 \pm 0,13$ & $5,23 \pm 0,01$ & LIZL/0 & $0,00 \pm 0,00$ & $0,00 \pm 0,00$ & $\mathrm{LIH} / 0$ & $3,29 \pm 0,16$ & $3,33 \pm 0,07$ & LIZL/0 & $3,33 \pm 0,07$ & $3,31 \pm 0,05$ \\
\hline $\mathrm{LIH} / 5$ & $4,97 \pm 0,08$ & $5,23 \pm 0,02$ & LIZL/5 & $0,00 \pm 0,00$ & $0,00 \pm 0,00$ & $\mathrm{LIH} / 5$ & $3,30 \pm 0,11$ & $3,34 \pm 0,09$ & LIZL/5 & $3,29 \pm 0,10$ & $3,30 \pm 0,07$ \\
\hline LIH/15 & $5,02 \pm 0,09$ & $5,22 \pm 0,01$ & LIZL/15 & $0,00 \pm 0,00$ & $0,00 \pm 0,00$ & LIH/15 & $3,38 \pm 0,13$ & $3,39 \pm 0,13$ & LIZL/15 & $3,36 \pm 0,11$ & $3,35 \pm 0,09$ \\
\hline LIH/25 & $5,02 \pm 0,08$ & $5,21 \pm 0,01$ & LIZL/25 & $0,00 \pm 0,00$ & $0,00 \pm 0,00$ & LIH/25 & $3,37 \pm 0,11$ & $3,09 \pm 0,09$ & LIZL/25 & $3,18 \pm 0,13$ & $3,16 \pm 0,15$ \\
\hline $\mathrm{LD} / 0$ & $5,57 \pm 0,19$ & $5,62 \pm 0,06$ & & & & $\mathrm{LD} / 0$ & $3,95 \pm 1,22$ & $3,91 \pm 0,70$ & & & \\
\hline $\mathrm{LD} / 5$ & $5,38 \pm 0,02$ & $5,60 \pm 0,06$ & & & & $\mathrm{LD} / 5$ & $4,58 \pm 0,71$ & $4,01 \pm 0,53$ & & & \\
\hline $\mathrm{LD} / 15$ & $6,05 \pm 0,11$ & $6,12 \pm 0,30$ & & & & $\mathrm{LD} / 15$ & $3,85 \pm 0,72$ & $4,00 \pm 0,57$ & & & \\
\hline $\mathrm{LD} / 25$ & $5,39 \pm 0,02$ & $5,59 \pm 0,19$ & & & & $\mathrm{LD} / 25$ & $4,59 \pm 0,70$ & $4,35 \pm 0,13$ & & & \\
\hline
\end{tabular}

Médias seguidas de mesma letra maiúscula na coluna e de mesma letra minúscula na linha não diferem estatisticamente pelo Teste de Tukey a 5\% de probabilidade.

LINH - Leite Integral Não Homogeneizado; LIH - Leite Integral Homogeneizado; LD - Leite Desnatado; LDZL - Leite Desnatado Zero Lactose; LIZL - Leite Integral Zero Lactose. 
Tabela 2A. Valores médios referentes ao teor de gordura e de teor de sólidos não gordurosos em leite com diferentes composições (S) submetidos a ozonização em diferentes de concentração e período de exposição (P)

\begin{tabular}{|c|c|c|c|c|c|c|c|c|c|c|c|}
\hline \multicolumn{6}{|c|}{ Teor de gordura $(\%)$} & \multicolumn{6}{|c|}{ Teor de sólidos não gordurosos (\%) } \\
\hline \multirow{2}{*}{$\begin{array}{l}\mathrm{S} \times \mathrm{P} \\
(\min )\end{array}$} & \multicolumn{2}{|c|}{ Concentração (mg/L) } & \multirow{2}{*}{$\begin{array}{l}S \times P \\
(\min )\end{array}$} & \multicolumn{2}{|c|}{ Concentração (mg/L) } & \multirow{2}{*}{$\begin{array}{l}S \times P \\
(\min )\end{array}$} & \multicolumn{2}{|c|}{ Concentração (mg/L) } & \multirow{2}{*}{$\mathrm{S} \times \mathrm{P}(\min )$} & \multicolumn{2}{|c|}{$\begin{array}{c}\text { Concentração } \\
(\mathrm{mg} / \mathrm{L})\end{array}$} \\
\hline & 21 & 31 & & 21 & 31 & & 21 & 31 & & 21 & 31 \\
\hline LINH/0 & $3,44 \pm 0,01 \mathrm{Aa}$ & $3,41 \pm 0,01 \mathrm{Aa}$ & LDZL/0 & $0,11 \pm 0,07$ & $0,12 \pm 0,07$ & LINH/0 & $9,04 \pm 0,13 \mathrm{Aa}$ & $9,05 \pm 0,13 \mathrm{Aa}$ & $\mathrm{LDZL} / 0$ & $11,50 \pm 0,17$ & $11,50 \pm 0,17$ \\
\hline LINH/5 & $3,47 \pm 0,24 \mathrm{Aa}$ & $3,14 \pm 0,22 \mathrm{Ab}$ & LDZL/5 & $0,03 \pm 0,03$ & $0,03 \pm 0,03$ & LINH/5 & $9,21 \pm 0,02 \mathrm{Aa}$ & $9,56 \pm 0,32 \mathrm{Aa}$ & $\mathrm{LDZL} / 5$ & $11,33 \pm 1,35$ & $10,87 \pm 0,49$ \\
\hline LINH/15 & $3,41 \pm 0,07 \mathrm{Aa}$ & $3,13 \pm 0,16 \mathrm{Ab}$ & LDZL/15 & $0,20 \pm 0,13$ & $0,17 \pm 0,14$ & LINH/15 & $9,16 \pm 0,14 \mathrm{Aa}$ & $8,59 \pm 0,33 \mathrm{Bb}$ & LDZL/15 & $11,20 \pm 0,26$ & $10,77 \pm 0,21$ \\
\hline LINH/25 & $3,58 \pm 0,06 \mathrm{Aa}$ & $2,70 \pm 0,17 \mathrm{Bb}$ & LDZL/25 & $0,04 \pm 0,04$ & $0,04 \pm 0,04$ & LINH/25 & $9,21 \pm 0,02 \mathrm{Aa}$ & $7,47 \pm 0,70 \mathrm{Cb}$ & LDZL/25 & $11,37 \pm 0,38$ & $11,20 \pm 0,10$ \\
\hline $\mathrm{LIH} / 0$ & $3,19 \pm 0,15$ & $3,19 \pm 0,15$ & LIZL/0 & $3,37 \pm 0,22$ & $3,13 \pm 0,18$ & $\mathrm{LIH} / 0$ & $9,28 \pm 0,08$ & $9,28 \pm 0,08$ & LIZL/0 & $9,28 \pm 0,08$ & $9,28 \pm 0,08$ \\
\hline $\mathrm{LIH} / 5$ & $3,59 \pm 0,97$ & $3,06 \pm 0,08$ & LIZL/5 & $3,13 \pm 0,17$ & $3,29 \pm 0,09$ & $\mathrm{LIH} / 5$ & $9,24 \pm 0,15$ & $9,30 \pm 0,11$ & LIZL/5 & $9,24 \pm 0,15$ & $9,30 \pm 0,11$ \\
\hline LIH/15 & $3,35 \pm 0,68$ & $3,41 \pm 0,55$ & LIZL/15 & $3,21 \pm 0,02$ & $3,15 \pm 0,05$ & LIH/15 & $9,34 \pm 0,16$ & $9,31 \pm 0,13$ & LIZL/15 & $9,34 \pm 0,16$ & $9,31 \pm 0,13$ \\
\hline LIH/25 & $3,36 \pm 0,69$ & $2,94 \pm 0,07$ & LIZL/25 & $3,12 \pm 0,24$ & $3,03 \pm 0,08$ & $\mathrm{LIH} / 25$ & $9,32 \pm 014$ & $8,99 \pm 0,11$ & LIZL/25 & $9,32 \pm 0,14$ & $8,98 \pm 0,11$ \\
\hline $\mathrm{LD} / 0$ & $0,18 \pm 0,18$ & $0,03 \pm 0,05$ & & & & $\mathrm{LD} / 0$ & $10,57 \pm 0,06$ & $10,57 \pm 0,06$ & & & \\
\hline $\mathrm{LD} / 5$ & $0,12 \pm 0,21$ & $0,01 \pm 0,02$ & & & & $\mathrm{LD} / 5$ & $10,43 \pm 0,12$ & $10,57 \pm 0,05$ & & & \\
\hline $\mathrm{LD} / 15$ & $0,46 \pm 0,01$ & $0,48 \pm 0,03$ & & & & $\mathrm{LD} / 15$ & $10,33 \pm 0,15$ & $9,94 \pm 0,02$ & & & \\
\hline $\mathrm{LD} / 25$ & $0,11 \pm 0,20$ & $0,00 \pm 0,00$ & & & & $\mathrm{LD} / 25$ & $10,43 \pm 0,12$ & $10,58 \pm 0,15$ & & & \\
\hline
\end{tabular}

Médias seguidas de mesma letra maiúscula na coluna e de mesma letra minúscula na linha não diferem estatisticamente pelo Teste de Tukey a 5\% de probabilidade. LINH - Leite Integral Não Homogeneizado; LIH - Leite Integral Homogeneizado; LD - Leite Desnatado; LDZL - Leite Desnatado Zero Lactose; LIZL - Leite Integral Zero Lactose. 